\title{
EXPRESSÃO E CARACTERIZAÇÃO DAS PROTEÍNAS VP1 E VP2 DE PARVOVÍRUS HUMANO B19 \\ EM Pichia pastoris
}

\author{
CLAUDIONOR GOMES DA SILVA FILHO
}

Tese (Doutorado) apresentada ao Programa de Pós-graduação Interunidades em Biotecnologia EP/ FMVZ/ IPT/ IB/ICB/ Butantan, para obtenção do Título de Doutor em Biotecnologia. 


\section{EXPRESSÃO E CARACTERIZAÇÃO DAS \\ PROTEÍNAS VP1 E VP2 DE PARVOVÍRUS HUMANO \\ B19 EM Pichia pastoris}

\section{CLAUDIONOR GOMES DA SILVA FILHO}

Tese (Doutorado) apresentada ao Programa de Pós-graduação Interunidades em Biotecnologia EP/ FMVZ/ IPT/ IB/ ICB/ Butantan, para obtenção do Título de Doutor em Biotecnologia.

Área de Concentração: Biotecnologia

Orientadora: Prof ${ }^{\mathrm{A}}$. Dra. Elisabete José Vicente Co-Orientador: Prof. Dr. Edison Luiz Durigon

São Paulo 2007

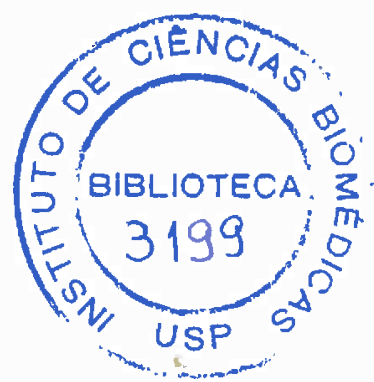


DADOS DE CATALOGAÇÃO NA PUBLICAÇÃO (CIP)

Serviço de Biblioteca e Informação Biomédica do

Instituto de Ciências Biomédicas da Universidade de São Paulo

reprodução não autorizada pelo autor

T-ICB

BIOT

QH323.6

$\mathrm{S} 586 \mathrm{ec}$

2007
Silva Filho, Claudionor Gomes.

Expressão e caracterização das proteínas VP1 e VP2 de parvovírus humano B19 em Pichia pastoris / Claudionor Gomes Silva Filho. -São Paulo, 2007.

Orientador: Elisabete Jose Vicente.

Tese (Doutorado) - Universidade de São Paulo. Instituto de Ciências Biomédicas. Programa de Pós-Graduação Interunidades em Biotecnologia EP/FMVZ/IPT/IB/ICB/Butantan. Área de concentração: Biotecnologia. Linha de pesquisa: Expressão de proteínas recombinantes.

Versåo do título para o inglês: Expression and characterization of VP1 and VP2 proteins of the human parvovirus B19 in Pichia pastoris.

Descritores: 1. Proteínas 2. Expressão gênica 3. Pichia pastoris 4. Parvovirus humano B19 I. Vicente, Elisabete Jose II. Universidade de São Paulo. Instituto de Ciências Biomédicas. Programa de PósGraduação em Biotecnologia. III. Título. 
Candidato(a): $\quad$ Claudionor Gomes Silva Filho.

Título da Tese: $\quad$ Expressão e caracterização das proteínas VP1 e VP2 de parvovírus humano B19 em Pichia pastoris .

Orientador(a): $\quad$ Elisabete Jose Vicente.

A Comissão Julgadora dos trabalhos de Defesa da Tese de Doutorado, em sessão pública realizada a ......10 $1 . \ldots . .1 \ldots .12 \ldots \ldots . . .2007 \ldots . .$, considerou

WAprovado(a) ( ) Reprovado(a)

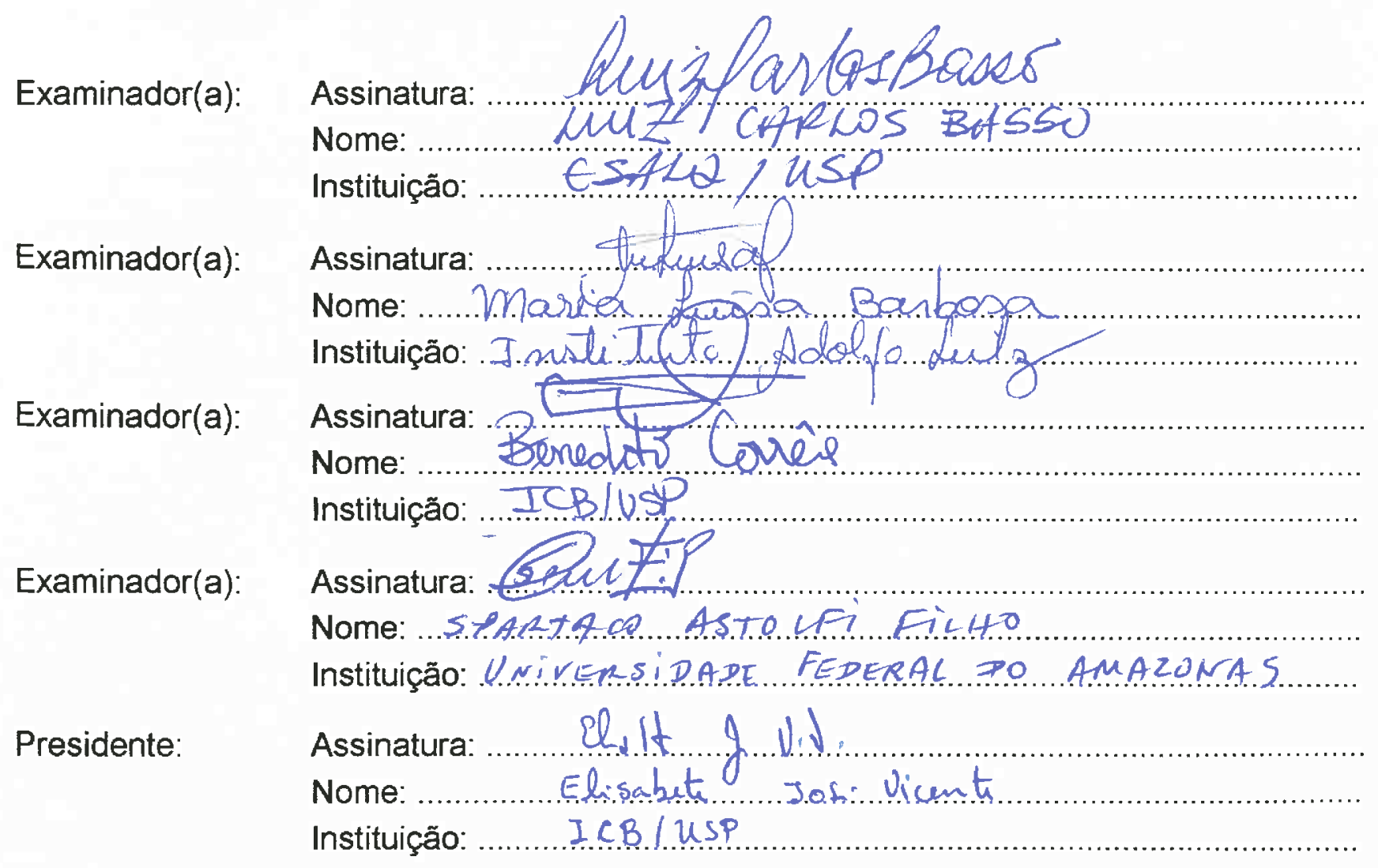




\section{DECLARAÇÃO}

Em adendo ao Certificado de Isençāo CEP-ICB $n^{\circ} 167$, informo que o titulo do Projeto foi alterado para "Expressão e caracterização das proteínas VP1 e VP2 de parvovírus humano B19 em Pichia pastoris ", sem modificaçōes de seu conteúdo.

São Paulo, 28 de agosto de 2007.

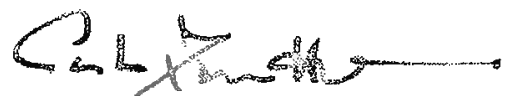

Prof. Dr. PAOLO M. A ZANOTTO

Vice-Coordenador CEPSH- ICB /USP

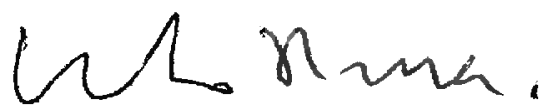

Prof. Dr. WOTHAN TAVARES DE LIMA Coordenador da CEEA - ICB/USP 


\section{CERTIFICADO DE ISENÇ̃̃O}

Certificamos que o Protocolo CEP-ICB $\mathrm{N}^{\circ} 167$, referente ao projeto intitulado "Expressão e purificação das protelnas VPI e VP2 de parvovírus humano B19 em Pichia pastoris" sob a responsabilidade de Claudionor Gomes da Silva Filho, foi analisado na presente data pela CEEA - COMISS̃̃O DE ÉTICA EM EXPERIMENTAÇ̃̃O ANIMAL e pela CEPSH COMISSÃo de Ética EM PESquisa COM SEREs humanos, tendo sido deliberado que o referido projeto não envolve manipulação animal ou humana que justifique uma aprovação quanto aos princípios éticos exigidos por ambas as Comissões.

São Paulo, 17 de agosto de 2006.

PRof. DF. UBIRANTAN Fabres Machado Coopdenador da CEEA - ICB/USP

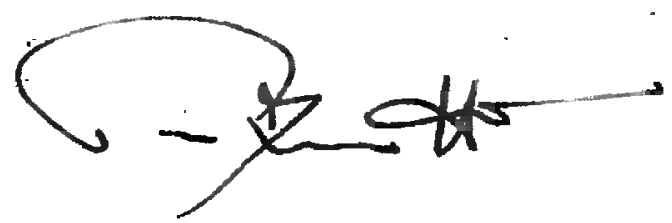

PROF. DR LUTZ VICENTE RIZZO Coordenador da CEPsh - ICB/USP 


\section{DEDICATÓRIA}

Aos meus pais Claudionor e Elisia, por me ensinarem a acreditar nos meus ideais, e incentivo em todos os projetos da minha vida.

À minha querida esposa Hildenêr e minha linda filha Sara Sofia, pelo amor, carinho $e$ compreensão ao longo destes anos.

Amo vocês de montão... 


\section{AGRADECIMENTOS}

Uma das maiores alegrias da vida é saber, quando se torna necessário fazer uma lista de agradecimentos como esta, que há muitas pessoas a lembrar e que ajudaram ao longo dos anos e de diversas maneiras a superar as dificuldades e a enriquecer os momentos felizes.

Ao meu Deus, pelo seu infinito amor e presença constante em todos os momentos da minha vida.

À Prof ${ }^{\mathrm{a}}$. Dr ${ }^{\mathrm{a}}$. Elisabete José Vicente, pela orientação, amizade, e pelos ensinamentos aprendidos ao longo desses últimos anos.

Ao Prof. Dr. Edison Luiz Durigon pela co-orientação, amizade e os muitos momentos de diversão e principalmente por acreditar que eu seria capaz de realizar este trabalho.

Aos professores: Ana Clara Schenberg, Gabriel Padilla, Luís Carlos Ferreira, Rita de Cássia Café Ferreira, pela colaboração científica.

Ao pesquisador Alexandre Pereira do Instituto Butantan, pela amizade e contribuição na caracterização dos antígenos.

A Dra. Maria Luiza Barbosa, pela amizade e contribuição neste trabalho.

Aos alunos pesquisadores do Laboratório de Genética Molecular de Microrganismos: Ana Raquel, Andréa Balan, Andreia Gouveia, Carol, Cleide, Charlote, Gabriela, Karen, Hugo, Ilana, Jéssica, Léa, Maria, Oeber, Priscila, Rafael, Ronaldo, Silene, Ruan, Tatiana, pela amizade, colaboração, pelos momentos de divertimento e por tudo ao longo deste período.

Ao meu grande amigo Odanir Gracia Guerra, que me ensinou os primeiros passos em biologia molecular.

A Dra. Danielle Bruna, pela amizade, apoio incondicional e momentos alegres.

Aos alunos pesquisadores do Laboratório de Virologia Clinica e Molecular do ICB II; "Edisolândia", pela cooperação e amizade ao longo destes anos.

A Ildenir pelo apoio dado, no cuidado com a minha filha Sara Sofia.

Aos estagiários Thiago, Gustavo, Regiane e Rute pelo auxílio.

Às técnicas do Laboratório de Genética Molecular de microrganismos Kazui, Leninha, e Norma pela amizade, carinho, apoio incondicional, obrigado por tudo.

Aos profissionais da secretaria de biotecnologia e biblioteca pelo apoio em tudo.

Aos meus irmãos na fé, pelas orações e momentos de reflexões.

A CAPES, pelo apoio financeiro.

A todos que direta ou indiretamente contribuíram para a realização deste trabalho. 
"Feliz o homem que acha sabedoria, $e$ o homem que adquire conhecimento; porque melhor é o lucro que ela dá do que o da prata, e melhor a sua renda do que o ouro mais fino".

(Provérbios 3:13-14) 


\section{RESUMO}

Silva Filho, CG. Expressão e caracterização das proteinas VP1 e VP2 de parvovírus humano B19 em Pichia pastoris. [Tese (Doutorado em Biotecnologia)]. São Paulo: Instituto de Ciências Biomédicas-USP/ IPT/ I. Butantan; 2007.

O parvovírus B19 é o agente causador de vários quadros clínicos incluindo eritemas infecciosos em crianças, hidropsia fetal em mulheres gestantes, anemia crônica e crise aplástica transitória. A levedura $P$. pastoris é um sistema de expressão muito empregado na produção de várias proteínas heterólogas. $\mathrm{O}$ objetivo deste trabalho foi expressar as proteínas VP1 e VP2 do parvovírus humano B19 na levedura $P$. pastoris. As seqüências codificadoras de VP1 e VP2 foram amplificadas por PCR, usando DNA total viral, os produtos obtidos foram inicialmente subclonados no vetor pGEM-TEasy. Os fragmentos de DNA foram digeridos EcoRI e Not I, purificados e inseridos no vetor de expressão e excreção de $P$. pastoris pPIC9K, entre os sítios EcoRI e NotI. Os plasmidios recombinantes foram linearizados com SalI e introduzido na linhagem P. pastoris GS115 (his4), por eletroporação, resultando em transformantes com fenótipo Mut+. Para a expressão das proteínas VP1 e VP2 do vírus $\mathrm{B} 19$, os clones recombinantes foram crescidos em glicerol, e a indução das proteínas foi realizada mediante adição de metanol, inicialmente em frascos erlenmeyers agitados. Este procedimento permitiu a seleção dos clones recombinantes: GS115/pPIC9K (controle negativo), GS115/pPIC9K-VP1 $13, \quad$ GS115/pPIC9K-VP1 $19, \quad$ GS115/pPIC9K-VP2 $2_{05}$, GS115/pPIC9K-VP2 10 que expressaram os maiores niveis das proteínas recombinantes VP1 e VP2. Estes clones recombinantes foram empregados na expressão em biorreator de $4 \mathrm{~L}$. A expressão de cada um dos antígenos VP1 e VP2 recombinantes foi analisada por SDS-PAGE e as atividades biológicas foram confirmadas pelos ensaios imunológicos ELISA, "Dot-Blot" e "Western Blot".

Palavras-Chaves: Pichia pastori, Proteína VP1, Proteina VP2, Parvovírus B19. 


\section{ABSTRACT}

Silva Filho, CG. Expression and Characterization of VP1 and VP2 Proteins of the Human Parvovirus B19 in P. pastoris. [Ph. D. Thesis (Biotechnology)]. São Paulo: Instituto de Ciências Biomédicas da Universidade de São Paulo; 2007.

The Human Parvovirus B19 is the causative agent of erythema infectiosum in children, hydrops fetalis in pregnant women and in other populations, such as individuals immunocompromised and with hematological diseases. It may also cause chronic anemia and aplastic crisis. The objective of this work was to express the VP1 and VP2 proteins of the human parvovirus B19 in the yeast $P$. pastoris, whose expression system is used for the production of various recombinant heterologous proteins. The coding sequence of VP1 and VP2 were amplified by PCR, using the DNA virus of B19 as template. The PCR-products were initially subcloned in the vector pGEM-TEasy. The DNA fragment EcoRI and NotI were excised, purified, and inserted between the sites EcoRI and NotI of the P. pastoris expressionsecretion vector $\mathrm{pPIC9K}$. The recombinant plasmids were linearized with SalI and introduced into the strain P. pastoris GS115 (his4) by electroporation, resulting in transformants with phenotypes Mut+. For heterologous expression of the proteins VP1 and VP2 of the human parvovirus B19, the transformants were grown in glycerol and induced by the addition of methanol initially in agitated erlenmeyers. This procedure alowed the selection of the best yeast recombinant clones: GS115/pPIC9K (negative control); and GS115/pPIC9K-VP $1_{13}$, GS115/pPIC9K-VP1 19 , GS115/pPIC9K-VP2 ${ }_{05}$, GS115/pPIC9K-VP2 ${ }_{10}$ measured by the high expression of VP1 and VP2 recombinant proteins. These recombinant clones were then grown in 4L biorreator. Each expressed recombinant antigens VP1 and VP2 produced were analyzed by SDS-PAGE and its biological activity were confirmed through Enzyme immunoassay EIA, Dot Blot and Western Blot.

Key words: Pichia pastoris. VP1 protein, VP2 protein, parvovírus B19. 


\section{LISTA DE ILUSTRAÇÕES}

Figura 1 - Mapa de transcrição do vírus B19. As barras abertas indicam as frentes de leitura (Heegaard e Brown, 2002).....

Figura 2 - Metabolismo do metanol ocorrido nas leveduras metilotróficas:

Figura 3 - Diagrama representativo do processo fermentativo na produção de proteínas heterólogas utilizando P. pastoris. $\quad$ Crescimento celular (\%), $\quad$ produção (\%) (Kobayashi, 2006).

Figura 4A - Mapa da construção dos plasmídios pHIL-D2 e pPIC9K (Invitrogen ${ }^{\circledR}$ ). AI - pHIL-D2 (8,2kb); AII - pPIC9K(9,3 kb).

Figura 4B - Esquema de integração do vetor de transformação no genoma de Pichia pastoris: (A, B) mecanismo de integração por inserção; e (C) mecanismo de integração por substituição (Daly et al., 2005).....

Figura 5 - Esquema de anelamento dos primers utilizado na amplificação dos genes que codificam as proteínas VP1 e VP2.

Figura 6 - Frascos erlenmeyers com haletas, adaptados para uso neste trabalho de expressão das proteínas produzidas pelos clones recombinantes de $P$. pastoris, cultivadas em frascos agitados.

Figura 7 - Fotografia do biorreator BIOSTAT ${ }^{\circledR} \mathrm{B}$, com volume máximo de $4 \mathrm{~L}$ 61

Figura 8 - Peso molecular relativo de cada uma das proteínas caracterizadas no SDSPAGE.

Figura 9 - Esquema de construção do plasmídio pGEM-TEasy-VP1, a partir do DNA total do vírus B19 (Durigon et al 1993, Erdman 1996).

Figura 10 - Esquema de construção do plasmídio pGEM-TEasy-VP2, a partir do DNA total do vírus B19 (Durigon et al 1993, Erdman 1996).

Figura 11 - Fragmentos de DNA VP1 e VP2 amplificado por PCR submetido a gel de agarose $0,7 \%$.

Figura 12 - Fragmentos de DNA VP1 e VP2 eluídos do gel de agarose $0,7 \%$ :

Figura 13 - Gel de agarose $0,7 \%$ submetido a eletroforese; A: pGEM-TEasy-VP1 $1 \ldots \ldots \ldots .73$

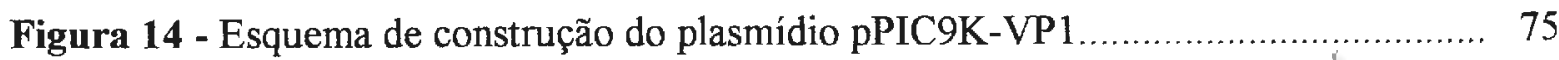

Figura 15 - Esquema de construção do plasmídio pPIC9K-VP2 ............................. 76 
Figura 16 - Gel de agarose $0,7 \%$ submetido a eletroforese:

Figura 17 - Esferograma do sequenciamento do plasmídio pPIC9K-VP1, com a região de inserção do primer Pvl e o sítio de restrição Eco RI, juntamente com o quadro da fase correta de leitura.

Figura 18 - Esferograma do sequenciamento do plasmídio pPIC9K-VP2, com a região de inserção do primer Pv2 e o sito de inserção EcoRI, juntamente com o quadro correto da fase de leitura.

Figura 19 - Análise da seqüência da proteína recombinante VP1 que será produzida pelo cloneGS115/pPIC9K-VP1 (Shade et al., 1986).

Figura 20 - Análise da seqüência da proteína recombinante VP2 que será produzida pelo cloneGS1 15/pPIC9K-VP2 (Shade et al., 1986).

Figura 21 - Representação esquemática dos passos experimentais realizados para a obtenção dos clones recombinantes de $P$. pastoris expressando e secretando as proteínas VP1 e VP2 recombinantes.

Figura 22 - Clones da levedura $P$. pastoris recombinantes GS115/pPIC9K-VP1 (A e C); e GS115/pPIC9K-VP2 (B e D), cultivados em meio sólido YPD + geneticina G418, nas concentrações de $0,5 \mathrm{mg} / \mathrm{mL}$ (A e B) e $4 \mathrm{mg} / \mathrm{mL}$ (C e D).

Figura 23 - Frascos erlenmeyers contendo culturas de $P$. pastoris GS1 15 recombinantes crescidas em meio MD glicerol (34 horas) e subseqüente indução de proteína recombinante com metanol ( 96 horas).

Figura 24 - Gel de SDS-poliacrilamida 12,5\%, após corrida eletroforética e coloração com "Coomassie Blue R250".

Figura 25 - Curva de crescimento dos clones recombinantes da linhagem $P$. pastoris GS115

Figura 26 - Curva de crescimento dos clones recombinantes, GS115/pPIC9K-VP1 ${ }_{13}$, GS115/pPIC9K-VP1 $1_{19}$, e GS115/pPIC9K-VP2 $2_{10}$ em meio de cultura FM22, no biorreator de 4 litros.

Figura 27 - Cultura crescida em biorreator de $4 \mathrm{~L}$, do clone recombinante de $P$. pastoris GS1 15/pPIC9K-VP $1_{13}$.

Figura 28 - Células do clone recombinante GS115/pPIC9K-VP1 13 (isoladas de cultura em biorreator de 4 litros, microscopia óptica com (aumento de 1000X).

Figura 29 - Análise dos antígenos VP1 e VP2 pela reação de "Dot-Blot" frente ao soro positivo pelo vírus B19, como controle foi usado soro normal.

Figura 30 - Análise do antígeno VP1 sobrenadante, frente ao soro positivo para vírus B19 e soro normal. O antígeno utilizado foi VP1 na concentração de $20 \mu \mathrm{g} / \mathrm{mL}$ 
- Figura 31 - Análise do antígeno VP1 semi-purificada, frente ao soro positivo para o vírus B19 e soro normal. O antígeno utilizado foi VP1 na concentração de $25 \mu \mathrm{g} / \mathrm{mL}$.

- Figura 32 - Análise do antígeno VP2 sobrenadante, frente ao soro positivo para vírus B19 e soro normal. O antígeno utilizado foi VP2 na concentração de $15 \mu \mathrm{g} / \mathrm{mL}$

Figura 33 - Análise do antígeno VP2 semi-purificado, frente ao soro positivo pelo B19 e soro normal. $\mathrm{O}$ antígeno utilizado foi VP2 na concentração de $10 \mu \mathrm{g} / \mathrm{mL}$

Figura 34 - Títulos de anticorpos frente aos antígenos recombinantes VP1 e VP2, como controle soro humano normal.

Figura 35 - Razão entre os títulos de anticorpos frente os antígenos recombinantes VP1 e VP2, como controle soro humano normal; I-VP1 e II-VP2.

Figura 36 - Gel de SDS-poliacrilamida $10 \%$, após corrida eletroforética e coloração com "Coomassie Blue".

Figura 37 - "Immunoblotting" dos antígenos recombinantes VP1 e VP2 frente anticorpos anti-B19. 


\section{LISTA DE TABELAS}

Tabela 1 - Dados comparativos de eficiência de produção de proteína entre diferentes organismos, baseados na massa de 1 kilograma no tempo de 24 horas, a partir de massa inicial de $1 \mathrm{Kg}$.

Tabela 2 - Proteínas expressas em sistema P. pastoris (Macauley-Patrick et al., 2005)... 36

Tabela 3 - Lista dos Plasmídios empregados neste trabalho. 44

Tabela 4 - Seqüência dos primers utilizados para a realização da PCR e sequenciamento

Tabela 5 - Parâmetros calculados para a determinação da massa molecular relativa de VP1 e VP2 protéicas resultantes da caracterização no "SDS-PAGE". Na coluna da direita, temos os valores dos pesos moleculares de cada uma das bandas proteínas visualizadas no gel (bandas), após a corrida eletroforética.

Tabela 6 - Número de colônias de transformantes $E$. coli DH5 $\alpha \mathrm{Amp}^{\mathrm{R}} \quad$ obtidas corr os plasmídios construídos neste trabalho.

Tabela 7 - Posição dos aminoácidos no sequenciamento de VP1 e VP2, que apresentaram mudanças no alinhamento com a seqüência padrão do vírus B19 GenBank (Shade et al., 1986)

Tabela 8 - Eficiência de transformação, por eletroporação, de $P$. pastoris GS115 com os vetores pPIC9K-VP1, pPIC9K-VP2 e pPIC9K.

Tabela 9 - Listas dos clones utilizados na expressão das proteínas VP1 e VP2, juntamente com o controle (pPIC9K vazio)...

Tabela 10 - Dados da massa úmida e biomassa das culturas dos clones recombinantes de $P$. pastoris obtidos em biorreator de 4 litros. 


\section{ABREVIATURAS}

aa:

Aminoácido

Abs

Absorbância

ade: Genótipo de deficiência na síntese de adenina em leveduras

$\mathbf{A p}^{\mathbf{R}}$ : $\quad$ Resistência à ampicilina

B19: Parvovírus humano B19

CAP: $\quad$ Região das proteínas de capsídeo

DNA: Ácido desoxirribonucléico

dNTP's: Deoxiribonucleosídeos 5'- trifosfatados (dATP, dTTP, dCTP, dGTP)

D.O. Densidade óptica

ELISA: $\quad$ Ensaio imunoenzimático

his: $\quad$ Genótipo de deficiência na síntese de histidina em leveduras

IgG: Imunoglobulina G

IgM: Imunoglobulina $\mathbf{M}$

IPTG: Isopropil B-D-tiogalactopiranosídeo

Kan: Gene de resistência a geneticina

Kb: $\quad 10^{3}$ pares de bases

KCl: Cloreto de potássio

kDa: Kilodalton ( $10^{3}$ daltons)

Kg Kilograma $\left(10^{3}\right.$ grama)

L: $\quad$ Litro $\left(10^{3} \mathrm{~mL}\right)$

leu: Genótipo de deficiência na síntese de leucina em leveduras

lys: Genótipo de deficiência na síntese de lisina em leveduras

M: $\quad$ Molar

MFa: $\quad$ Peptídeo sinal de fator $\alpha$

Mg: $\quad$ Miligrama $\left(10^{-3}\right.$ grama)

MgCl : $\quad$ Cloreto de magnésio

min: Minuto

mL: $\quad$ Mililitro ( $10^{-3}$ litro)

Ng: Nanograma ( $10^{-9}$ grama)

nm: Nanômetros $\left(10^{-9}\right.$ metro)

NS: $\quad$ Proteína não estrutural 
nt: Nucleotídeos

O.D. Oxigênio dissolvido

ORF: $\quad$ Fase Aberta de Leitura

pb: Pares de bases

PCR: Reação em cadeia pela polimerase

PEG: Polietilenoglicol

pg: Picograma $\left(10^{-12} \mathrm{~g}\right)$

pH: Potencial hidrogeniônico

pmol: Picomol $\left(10^{-12} \mathrm{M}\right)$

primer: Oligonucleotídeo iniciador

r.p.m.: Rotações por minuto

"SCP": $\quad$ Proteína unicelular ("single cell protein")

SD: $\quad$ Meio mínimo de cultivo de leveduras

SDS: $\quad$ Dodecil sulfato de sódio

SDS-PAGE: "Sodium dodecyl sulfate Polyacrylamide Gel Electrophoresis"

TAC: $\quad$ Crise aplastica transitória

TM: Temperatura de fusão "Melting Temperature"

TEMED: Tetrametil etilenoamina

VP1: $\quad$ Proteína estrutural do capsídeo 1 do vírus B19

VP2: $\quad$ Proteína estrutural do capsídeo 2 do vírus B19

X-gal: $\quad$ 5-bromo-4-cloro-3-indoil- $\beta$-D-galactosídeo

YPD: $\quad$ meio completo de cultivo de levedura

\%: $\quad$ Porcentagem

$\lambda: \quad$ Comprimento de onda

$\mu \mathrm{g}: \quad \quad$ Micrograma $\left(10^{-6} \mathrm{~g}\right)$

$\mu \mathrm{ll} \quad \quad \quad$ Microlitro $\left(10^{-6}\right.$ litros $)$ 


\section{LISTA DE SÍMBOLOS}

\section{Aminoácidos}

Alanina for

\section{Bases nitrogenadas dos nucleotídeos}

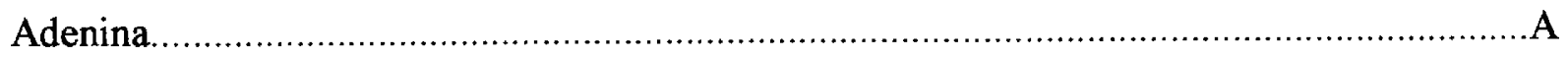

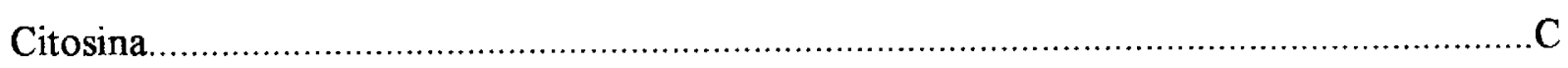

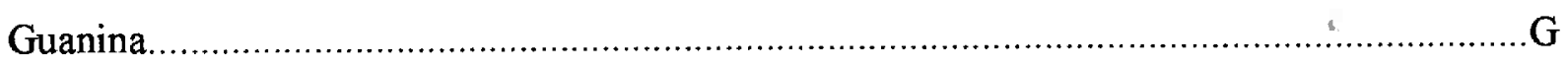

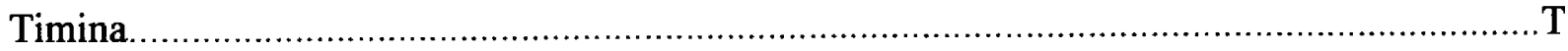




\section{SUMÁRIO}

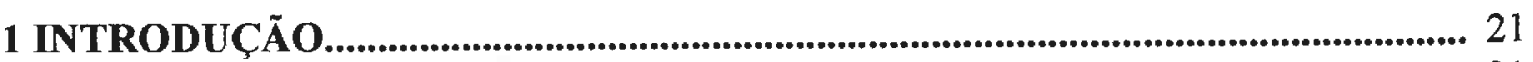

1.1 Parvovírus B19............................................................................................................... 21

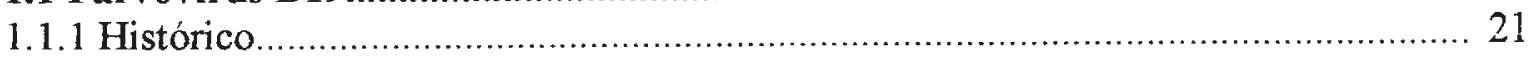

1.1.2 Organização genômica e características bioquímicas e moleculares do B19.......... 22

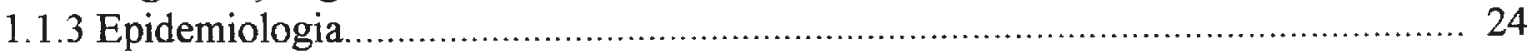

1.1.4 Principais manifestações clínicas associadas ao B19.......................................... 24

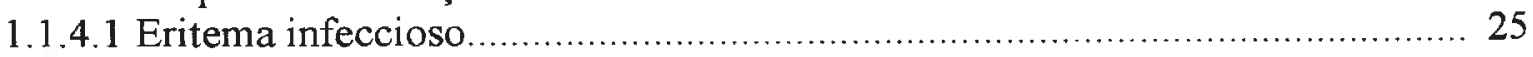

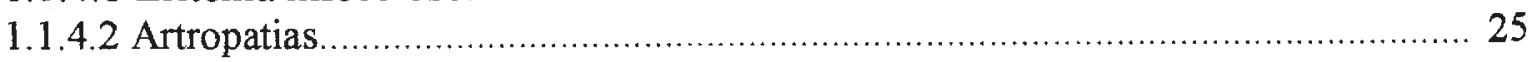

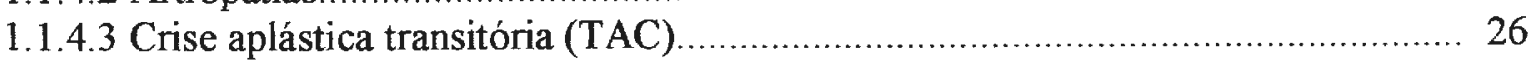

1.1.4.4 Infeç̧̃å durante a gravidez...................................................................... 26

1.1.4.5 Infecção pelo B19 e hepatite .................................................................... 27

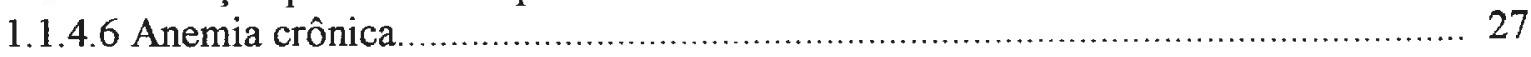

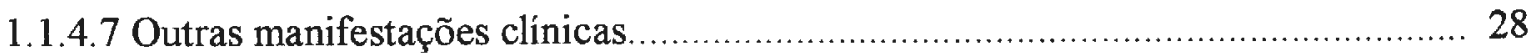

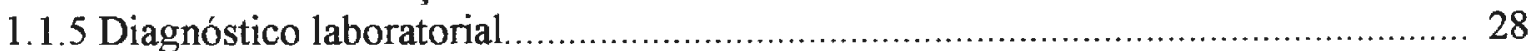

1.1.6 Proteínas VP1 e VP2 e sua aplicação diagnóstica............................................... 29

1.2 Expressão de genes heterólogos em levedura........................................................... 30

1.3 Pichia pastoris................................................................................................................... 32

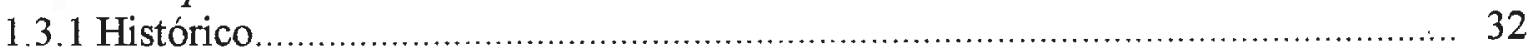

1.3.2 Expressão de gene heterólogos em P. pastoris ……......................................... 33

1.3.3 Vetores de clonagem e expressão..................................................................... 36

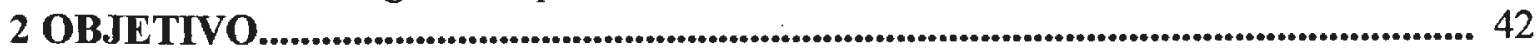

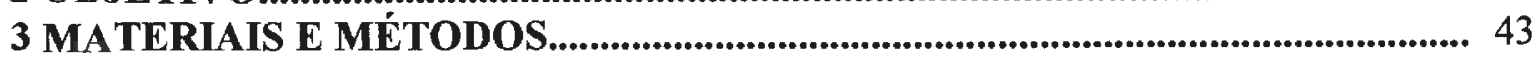

3.1 Linhagens de bactérias......................................................................................................... 43

3.2 Levedura........................................................................................................................... 43

3.3 Plasmídios................................................................................................................................... 44

3.4 Meios de cultura para o cultivo de bactérias................................................................ 45

3.4.1 Meio completo (Luria Bertani) - LB ............................................................. 45

3.4.3 Meio de recuperação - SOC ..................................................................... 45

3.5 Meios de cultura para o cultivo de levedura................................................................... 45

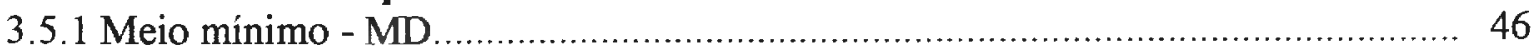

3.5.2 Meio completo - YP............................................................................ 46

3.5.3 Meio completo acrescido de glicose - YPD ……............................................ 46

3.5.4 Meio completo acrescido de metanol - YPM................................................... 46

3.5.5 Meio completo acrescido de glicerol - YPG .................................................... 46

3.5.6 Meio completo acrescido de glicose e antibiótico geneticina G418 ${ }^{\mathrm{R}}$ - YPD-G418.. 46

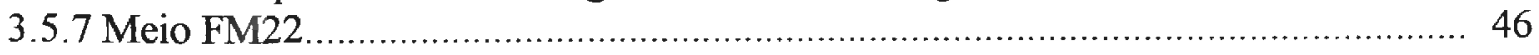

3.6 Soluções...................................................................................................................... 47

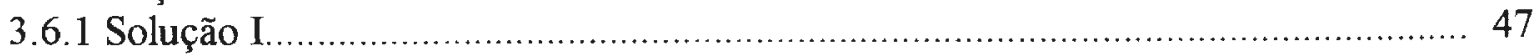

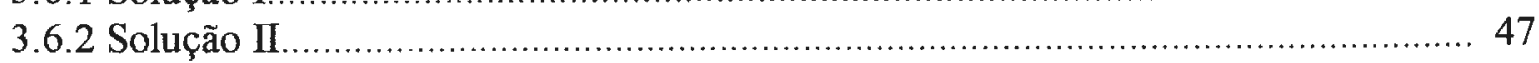

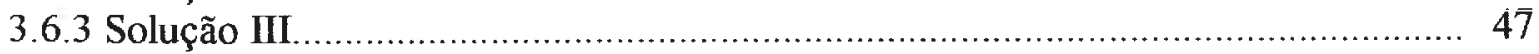

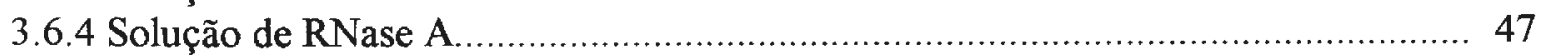

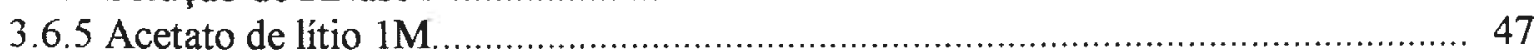

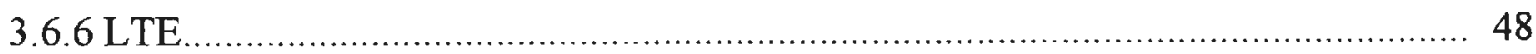

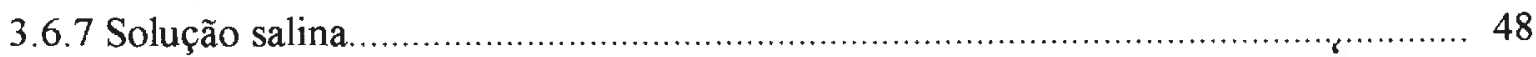

3.6.8 Solução estoque de brometo de etídeo - "EB" .................................................. 47

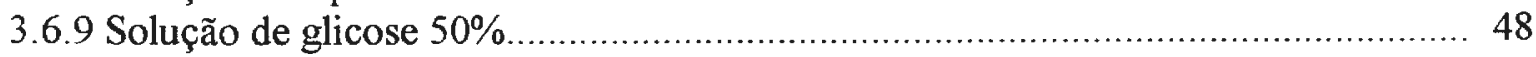


3.6.10 Solução clorofórmio-álcool isoamílico...................................................... 48

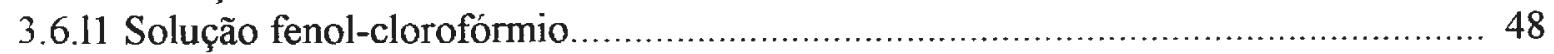

3.6.12 Solução desnaturante ………………………......................................... 48

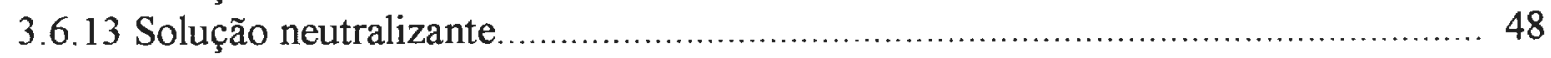

3.6.14 TE

3.6.15 TBE 10X

3.6.16 Tampão de corrida para eletroforese em gel de agarose - TBE 0,5X …........... 49

3.6.17 Tampão de amostra "Stop Mix" - 10X …………………………………........ 49

3.6.18 Tampão fosfato salino (PBS) .............................................................. 48

3.6.19 Solução de sais de PMT4 ................................................................ 49

3.7 Obtenção das Sequênciais gênicas VP1 e VP2 .................................................... 49

3.7.1 Estudo das seqüências VPl e VP2 ................................................... 49

3.7.2 Obtenção de amostra clínica com DNA viral positivo para B19....................... 49

3.7.3 Obtenção dos fragmentos de DNA codificadores dos genes VP1 e VP2 ............... 50

3.8 Purificação dos produtos da PCR................................................................................ 53

3.9 Sequenciamento dos genes codificadores de VP1 e VP2 clonados nos plasmídios recombinantes pPIC9K-VP1 e pPIC9K-VP2 ............................................. 53

3.9.1 Purificação ....................................................................................... 53

3.9.2 Processamento e alinhamento das seqüências codificadoras de VP1 e VP2 do

B19

3.10 Extração de DNA plasmidial de bactéria............................................................. 55

3.11 Tratamento de DNA plasmidial com enzimas de restrição................................... 55

3.12 Análise dos fragmentos de DNA em gel de agarose .......................... 55

3.13 Purificação dos fragmentos de DNA de gel de agarose ..................... 56

3.14 Desfosforilação de fragmentos de DNA........................................................................ 56

3.15 Ligação de fragmentos de DNAs............................................................................... 56

3.16 Transformação gênica............................................................................................................ 56

3.16.1 De células da bactéria $E$. coli ........................................................... 56

3.16.2 De células de levedura Pichia pastoris ........................................................ 57

3.16.2.1 Preparação das células..................................................................... 57

3.16.2.2 Transformação................................................................................... 57

3.17 Expressão das Proteínas recombinantes VP1 e VP2 em cultivo realizado em frascos agitados....................................................................................................................... 58

3.17.1 Cultivo dos clones recombinantes $P$. pastoris em frascos agitados .................... 58

3.17.2 Obtenção do estrato bruto concentrado das proteínas VP1 e VP2 expressas em

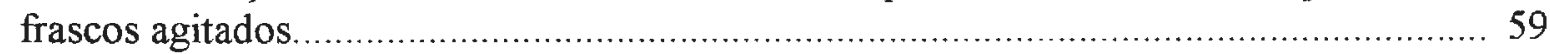

3.18 Análise da curva de crescimento dos clones recombinantes............................. 59

3.19 Eficiência de transformação dos plasmídios pPIC9K-VP1 e pPIC9K-VP2...... 59

3.20 Avaliação microscópica dos transformantes.......................................................... 60

3.21 Expressão das proteínas recombinantes VP1 e VP2 em biorreator de 4 L........ 60

3.21.1 Preparação do inóculo ......................................................................... 60

3.21.2 Cultivo dos clones recombinantes $P$. pastoris em biorreator de $4 \mathrm{~L}-$

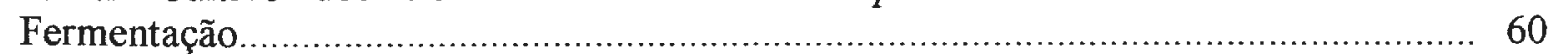

3.22 Preparo de antígenos..................................................................................................... 61

3.23 Dosagem de proteínas...................................................................................................... 62

3.24 Ensaio Imunoenzimático ELISA para a deteç̧ão de anticorpos anti-B19........ 62

3.25 Análise Eletroforética das proteínas recombinantes VP1 e VP2 em géis de poliacrilamida........................................................................................................................ 63

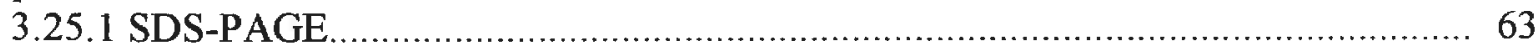

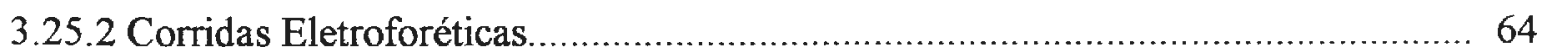


3.25.3 Coloração com "Coomassie Blue" .................................................................. 64

3.26 Determinação do peso molecular das proteínas recombinantes.......................... 64

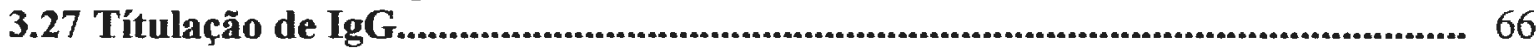

3.28 "Dot-Blot"

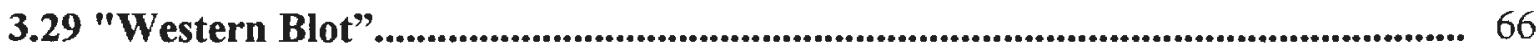

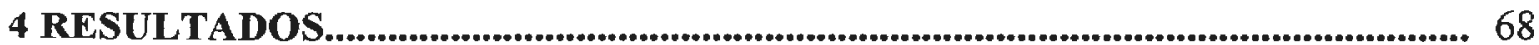

4.1 Clonagem dos genes codificadores das proténas VP1 e VP2 do vírus B19 vetor intermediário pGEM-TEasy......................................................................6 68

4.1.1 Obtenção dos fragmentos de DNA codificadores das proteínas VP1 e VP2 do

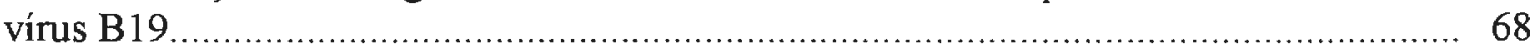

4.1.2 Clonagem dos fragmentos de DNAs VP1 e VP2 em pGEM-TEasy................... 72

4.2 Clonagem dos fragmentos de DNA codificadores de VP1 e VP2 no vetor de expressão e excreção de Pichia pastoris pPIC9K......................................................... 73

4.2.1 Extração Eluição dos fragmentos VP1 e VP2 dos plasmídios pGEM-TEasy-VP1

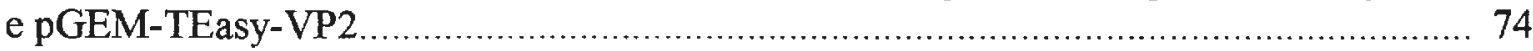

4.2.2 Clonagem dos fragmentos de DNA codificadores de VP1 e VP2 em pPIC9K..... 74

4.3 Sequenciamento genes VP1 e VP2 clonados nos plasmídios pPIC9K-VP1 e pPIC9K-VP2.

4.4 Análise das proteínas recombinantes VP1 e VP2 que seriam produzidas pelos clones $P$. pastoris recombinantes................................................................................ 81

4.5 Obtenção dos clones recombinantes de $P$. pastoris produtores de VP1 e VP2..... 84 4.5.1 Transformação da levedura $P$. pastoris com os vetores pPIC9K-VP1 e pPIC9KVP2

4.5.2 Seleção dos clones recombinantes resistentes a altas concentrações de genticina... 84

4.5.3 Seleção dos clones recombinantes ótimos produtores de VP1 e VP2 …................ 87

4.5.4 Curva de crescimento dos clones selecionados.................................................. 90

4.6 Produção das proteínas recombinantes VP1 e VP2 em biorreator de 4 litros.... 91

4.6.1 Cultivo em biorreator de 4 litros................................................................... 91

4.6.2 Análise da morfologia das células do clone recombinante GS1 15/pPIC9K-VP $1_{13}$,

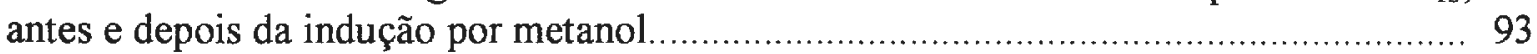

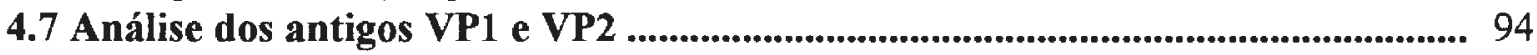

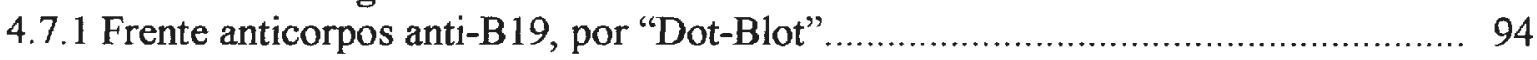

4.7.2 Frente anticorpos anti-B19 por ensaio imunoenzimático ELISA .......................... 95

4.7.3 Frente anticorpo anti-B19, por ensaio do Immunoblotting................................ 99

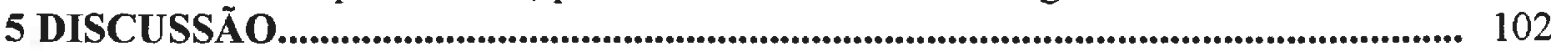

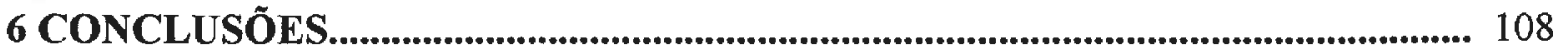

REFERÊNCIA BIBLIOGRÁFICAS............................................. 109

ANEXO A - Análise do sequenciamento do gene que codifica a proteína VP1 (2345

nt), clonada no plasmídio pPIC9K-VP1: alinhamento com a sequiência do vírus B19

(Ref. M13178, Shade et al., 1986) GenBank ............................................................. 121

ANEXO B - Análise do sequenciamento do gene que codifica a proteína VP2 (1664 nt), clonada no plasmídio pPIC9K-VP2: alinhamento com a seqüência do vírus B19 (Ref. M13178, Shade et al., 1986) GenBank. 


\section{INTRODUÇÃO}

\subsection{Parvovírus B19}

\subsubsection{Histórico}

Os parvovírus caracterizam-se por serem muito pequenos (parvo significa pequeno em latim) contendo ácido desoxirribonucléico (DNA) de fita simples. Abrangem uma ampla faixa de vírus de vertebrados e invertebrados. Até 1974, estes vírus estiveram associados somente às patologias de animais. Em 1975, na Inglaterra, Cossart et al observaram presença de vírus deste tipo em amostras de doadores de sangue assintomáticos. Essa descoberta ocorreu por acaso, quando as amostras de sangue humanos estavam sendo testadas quanto à presença do vírus da hepatite $\mathrm{B}$, por contraimunoeletroforese (CIE), e apresentaram resultado falsopositivo. A microscopia eletrônica revelou a presença de partículas muito pequenas ( $23 \eta \mathrm{m})$ com simetria icosaédrica, denominadas inicialmente, partículas no soro semelhante a parvovírus ("Serum Parvovirus-Like Particule" - SPLV) (Cossart et al., 1975; Erdman et al., 1996). Este vírus também já foi chamado de parvovírus humano.

Em 1985, o Comitê Internacional de Taxonomia classificou oficialmente este vírus como membro da família Parvoviridae. Sua identificação foi determinada a partir do soro estudado por Cossart et al. (1975), amostra 19 do painel B, sendo, então, oficialmente denominado B19 (Siegl et al., 1985).

Mais recentemente, baseando-se na habilidade de infectar células de vertebrados ou de invertebrados, a família Parvoviridae foi dividida em Parvovirinae e Densovirinae, respectivamente. Uma vez que infecta eritrócitos e não requer um vírus "helper" para produzir infecção, atualmente o vírus B19 (00.050.1.02.001) é classificado como membro do gênero Erythrovirus (00.050.1.02), sub-família Parvovirinae (00.050.1), família Parvoviridae (00.050) ("International Comittee on Taxonomy of Viruses", 2002" $<\underline{\underline{h t p}: / / w w w . n c b i . n l m . n i h . g o v / I C T V d b / I C T V d B / i n d e x . h t m>) . ~}$ 


\section{Introdução}

\subsubsection{Organização genômica e características estruturais e bioquímicas do vírus}

B19

As partículas virais, vírions, consistem em capsídios. Os vírions B 19 apresentam-se como esferas, com simetria icosaédrica, de diâmetro variando de $18-26 \eta \mathrm{m}$, destituídas de envelope e constituídas por 60 cópias de capsômeros quadrilaterais. São altamente resistentes a: pH 3,0-9,0; inativação térmica (resistentes a $56^{\circ} \mathrm{C}$, por 60 horas); e, solventes de lipídios. Entretanto, B19 pode ser inativado quando submetido à radiação gama, tratamento com oxidantes, formalina e betapropiolactona (Cohen e Brown, 1992; Berns, 1996; Heegaard e Brown, 2002).

Os vírions têm peso molecular 5,6 $10^{6} \mathrm{e}$, num gradiente de densidade de cloreto de césio, sedimentam em 1,41 g/mL (Berns, 1996; Young, 1995).

O genoma de B19 é representado por um único filamento de DNA linear (ssDNA), com $44 \%$ de conteúdo $\mathrm{C}+\mathrm{G}$. Ambas as fitas de DNA, as fitas de polaridade positiva ou de polaridade negativa, podem ser empacotadas nas partículas virais. (Deiss et al, 1990; Heegaard e Brown, 2002). Possui 5.596 nucleotídeos (nt), composto por uma seqüência interna de $4.830 \mathrm{nt}$ flanqueada por seqüências repetidas terminais (TRS) de $383 \mathrm{nt}$, cada. As seqüências terminais (TRS das extremidades 3' e 5') são estruturas palindrômicas idênticas (Deis et al., 1990) e são capazes de assumir configurações de grampo duplo, servindo como "primers" para síntese da fita complementar (Astell, 1990; Deiss et al., 1990; Berns, 1996).

Como na maioria dos parvovirus de animais, o genoma do vírus B19 possui duas grandes frentes de leitura abertas (ORFs - "Open Reading Frames"): A primeira ORF (terminal 5' do genoma), transcreve o único mRNA que não sofre processamento póstranscricional, e codifica a proteína não estrutural NS1 (77 kDa), que é importante na replicação viral e lise celular (Corcoran et al., 2004). Localizada à jusante de NS1, encontrase a ORF que codifica as duas proteínas estruturais do capsídeo (VP1 e VP2) (Figura 1) (Ozawa et al., 1987; Deiss et al., 1990; Luo e Astell 1993; Heegaard e Brown, 2002).

A transcrição de todas as proteínas do vírus B19 ocorre a partir de um único promotor (P6) localizado na extremidade 5' do genoma, resultando em, no mínimo, 9 “overlaping" mRNAs (Ozawa et al., 1987; Deiss et al., 1990; Luo e Astell 1993; Heegaard e Brown, 2002). 


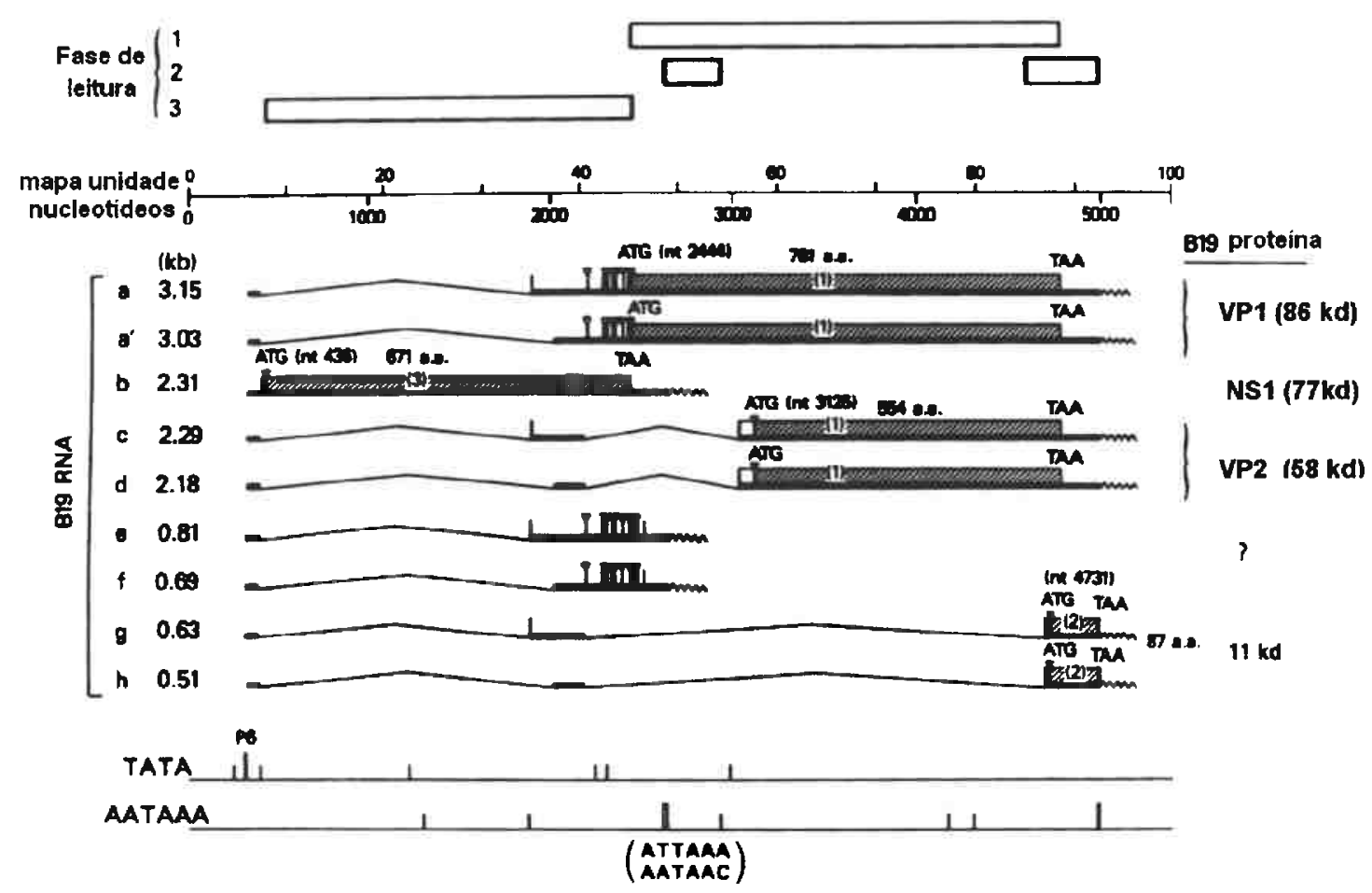

Figura 1 - Mapa de transcrição do virus B19. As barras abertas indicam as frentes de leitura abertas (ORFs - "Open Reading Frames") (Deiss et al., 1990; Heegaard e Brown, 2002).

O capsídeo do vírus B19 é formado por duas proteínas estruturais: VP1 (84 kDa), que representa 4\%; e, VP2 (58 kDa), que representa 96\%. Estas duas proteínas são codificadas pela mesma ORF (VP1 é codificada pelas seqüências de nt 2444-4786; e, VP2 pelos nt 3125 4786). A proteína VP1 é caracterizada por um domínio adicional de 227 aminoácidos, na região aminoterminal, denominada região única da VP1 (VP1u). As seqüências de aminoácidos da VP1 e VP2 são idênticas, exceto pelos 227 aminoácidos adicionais na extremidade aminoterminal de VP1 (Ozawa e Young., 1987; Heegaard e Brown, 2002; Tzang et al., 2007a; Tzang et al., 2007b).

A exata posição da região VP1u, como parte da proteína VP1, nos capsídeos é desconhecida. Considerando que os anticorpos neutralizantes IgM e IgG, produzidos durante a infecção, são dirigidos contra epítopos deste domínio, presume-se que a região VP1u seja exposta na superficie do vírus (Rosendfeld et al., 1992; Bansal et al., 1992). Os epítopos lineares dessa região, principalmente na porção aminoterminal, dos resíduos 1 ao 93 foram mapeados. A utilização de soro policlonal de coelho, produzido contra o capsídeo de B19, possibilitou a localização de diversos epítopos, em regiões formadas pelos aminoácidos 31 a 51 e 46 a 93 (Saikawa et al., 1993). Um epitopo reconhecido por anticorpos monoclonais foi 
mapeado nos resíduos 30 a 42 (Gigler et al., 1999).

Desde o primeiro sequenciamento do genoma de B19 (Shade et al., 1986), vários métodos de análises genômicas vêm sendo aplicados para o estudo dos inúmeros novos isolados, chegando-se à conclusão de que todos os vírus B19 são intimamente relacionados ("intimately clustered"), apresentando apenas $6 \%$ de divergência. NS1 é a proteína mais conservada, enquanto que VP1 e VP2 apresentam variabilidade entre 2-3\%. Não obstante, a região VP1u mostrar um grau elevado de variabilidade genômica, o que se reflete também numa variabilidade de aminoácidos traduzidos, a conformação deste domínio parece ser bem estável (Hemauer et al., 1996; Hokynar et al., 2000; Heegaard e Brown, 2002).

\subsubsection{Epidemiologia}

A presença de anticorpos da classe IgG anti-B19, em adultos, está em torno de $70 \%$ da população geral. Essa porcentagem é menor conforme a idade, variando entre $2 \%$ a $15 \%$ em crianças de 1 a 5 anos (Anderson et al., 1987; Cohen et al., 1988; Freitas et al., 1990; Nascimento et al., 1990).

A prevalência de anticorpos específicos anti-B19 pode aumentar se a população estiver mais exposta ao vírus, como nos casos de pacientes hemofilicos e politransfundidos, onde a prevalência de anticorpos da classe IgG pode chegar a 95\% (Mortimer et al., 1983).

Na cidade de São Paulo, foi encontrada uma incidência de 1/3000 do DNA de B19 em doadores de sangue empregando-se a técnica de "Nested-PCR" (Lisboa, 1997).

\subsubsection{Principais manifestações clínicas associadas ao B19.}

A infecção por B19 é comum em todo o mundo, podendo surgir em forma de epidemias de eritema infeccioso em escolas, creches, funcionários de hospitais ou em casos isolados (Gillespie et al., 1990; Pillay et al., 1992; Adler et al., 1993).

Em países de clima temperado, os surtos de eritema infeccioso começam no final do inverno e início da primavera, prolongando-se até o início do verão (Chorba et al., 1986). Novas epidemias podem ocorrer a cada 3 ou 5 anos (Anderson et al., 1985; Pillay et al., 1992). 


\subsubsection{Eritema infeccioso.}

O eritema infeccioso é uma doença comum, sobretudo na infância, ocorrendo geralmente entre os 5 e 14 anos, não obstante, pode ocorrer em adultos. Caracteriza-se por um exantema repentino na face expandindo-se, em seguida para o tronco e membros inferiores, com a aparência de um rendilhado sendo acompanhado de mal estar e febre (Herrick et al., 1962; Listernick, 1986).

O eritema infeccioso foi objeto de vários estudos que confirmaram sua associação com o vírus B19 (Nonoue et al., 1985; Plummer et al., 1985; Chorba et al., 1986). É a manifestação clínica mais comum, sendo, também, conhecido como a "quinta doença" (Beersma et al., 2005). O exantema não permanece mais que uma semana, podendo ocorrer reincidências sob estresse físico ou emocional (Anderson et al., 1983).

O diagnóstico clínico do eritema infeccioso é dificil, devido sua ocorrência em casos esporádicos e sua semelhança com outros quadros exantemáticos, tais como sarampo e rubéola, justifica a necessidade de uma melhor investigação laboratorial (Cubel et al., 1997).

Das complicações do eritema infeccioso, citam-se a artrite e a artralgia que são manifestações transitórias que acometem geralmente adultos jovens (Anderson et al., 1997).

\subsubsection{Artropatias}

Uma significante complicação do eritema infeccioso é a artropatia, a qual tem sido associada à infecção pelo B19 (Anderson et al., 1987). Os aspectos clínicos desta doença foram estudados por Reid et al. (1985), durante um surto de eritema infeccioso causado pelo B19, constatando-se o comprometimento das articulações. Nesse estudo, os pacientes apresentaram evidências sorológicas de recente infecção pelo B19. Os casos de artrite e artralgia são descritos em adultos jovens principalmente (Cassinot et al., 1998). A artrite aguda, a mais severa manifestação se resolve em poucos dias. Entretanto, pode ter um curso crônico prolongado em $20 \%$ dos casos, o que pode estar relacionado à persistência do vírus no líquido sinovial, membrana sinovial e medula óssea (Soderlund et al., 1997; Casinotti et al., 1998; Hokynar et al., 2000). Além disso, fatores genéticos e mecanismos imunes podem causar a reativação do vírus, quando em estado de latência na medula óssea. Nestes casos, o diagnóstico diferencial entre artrite reumatóide e artrite causada pelo vírus B19 se faz necessário, visto que tratamentos com imunossupressores, normalmente empregados para artrite reumatóide, podem prolongar a infecção pelo vírus B19 (Stoll et al., 1995). 


\subsubsection{Crise aplástica transitória (TAC)}

O termo crise aplástica transitória (TAC) foi designado por Owren em 1948, para relatar uma abrupta e severa anemia com ausência de reticulócitos em pacientes com esferocitose hereditária. Tais sintomas são contrários na crise hemolítica, onde a diferenciação celular na medula óssea é exacerbada e a contagem de reticulócitos é elevada.

A TAC foi a primeira doença associada ao B19 em humanos. Isto ocorreu quando em Londres, 600 amostras de soro provenientes de crianças imigrantes da Jamaica foram examinadas. Dessas amostras, 6 apresentaram evidências de infecção recente (Pattison et al., 1981). Além disso, as crianças com os sintomas de TAC apresentavam hemácias falciformes, redução do hematócrito e hipoplasia eritrocitária. Estudos utilizando soros de pacientes com anemia fa1ciforme colaboraram para associação da TAC à recente infecção por B19 (Anderson et al., 1982).

A crise aplástica é um episódio agudo que acomete pacientes com desordens hematológicas tais como: esferocitose hereditária, talassemia, deficiência de piruvato-kinase, anemia hemolítica auto imune, podendo ocorrer também sob condições de deficiência de ferro, hemorragia e transplante renal (Duncan et al., 1983; Young et al., 1988). Nesse episódio verifica-se a ocorrência de uma interrupção na produção de células vermelhas documentada pela redução do número de reticulócitos, (Pattison et al., 1981; Serjeant et al., 1981).

Os sintomas da doença incluem dispnéia, prostração, confusão mental (devido ao agravamento da anemia), podendo o paciente desenvolver falha congestiva cardíaca, necrose da medula óssea, além de poder ser fatal. $O$ tratamento geralmente é a transfusão sanguínea (Anderson et al., 1997).

\subsubsection{Infecção durante a gravidez}

A infecção pelo B19 durante o primeiro trimestre da gravidez pode levar à ocorrência de hidropsia fetal e abortos espontâneos, que são decorrentes da combinação de elevada formação de células vermelhas no feto e a imaturidade do seu sistema imune (Knott et al., 1984; Kinney et al., 1988; Brown et al., 1994; Lowden et al., 1997).

Estudos de patologia em fetos mostraram evidências de reação leucoeritroblástica no figado, sendo visualizado nas células pelos corpos de inclusão eosinófilos, condensação periférica, ou pela marginação da cromatina nuclear. Além disso, o DNA do B19 foi 
encontrado em tecidos fetais, empregando-se "Dot Blot" e hibridização in situ (Clewley et al., 1985; Yaegashi et al., 1994).

Os antígenos para o B19 foram detectados em células miocárdicas fetais, sugerindo que a miocardite fetal pode estar relacionada a esta patologia (Morey et al., 1991).

Em um estudo prospectivo realizado na Inglaterra, o risco de morte fetal devido à infecção pelo B19 foi estimado em $9 \%$ e a transmissão vertical, via placenta, em $33 \%$ dos casos ("Public Health Laboratory Service Working Party on Fifth Disease", 1990).

A hidropsia fetal pode desenvolver-se após duas semanas de gestação, e a morte do feto pode ocorrer após sete semanas subseqüentes ao desenvolvimento da hidropsia. Tanto a hidropsia quanto a morte fetal são devidas à infecção lítica dos precursores das células vermelhas pelo B 19 , seguida de interrupção da produção de eritrócitos. O resultado é uma severa anemia com níveis de hemoglobina chegando a $2 \mathrm{~g} / \mathrm{dL}$, e a ocorrência de falha congestiva cardiaca (Anderson et al., 1988; Smoleniec e Pillai, 1994; Torok et al., 1995).

Quando confirmada a infecção da mãe, do feto e o desenvolvimento da hidropsia, pode-se recorrer a transfusões sanguíneas, via cordoncentese, ou terapia alternativa com imunoglobulina (Odibo et al., 1998).

\subsubsection{Infecção pelo B19 e hepatite}

Há evidências atuais de associação do vírus B19 a alguns casos de hepatite severa. Em estudo realizado no estado de São Paulo, verificou-se a sua presença em 2,3\% de 129 brasileiros com hepatite aguda ou crônica, foram detectados anticorpos e DNA do B19 no soro e no figado desses pacientes, sugerindo uma possível correlação entre a doença e a infecção pelo B19 em alguns casos (Pinho et al., 2001). Foram também relatados a presença do DNA do B19 no tecido do figado, em casos de hepatite fulminante (Yoto et al., 1996; Langnas et al., 1995; Bernuau et al., 1999). A infecção pelo B19, após transplante de figado, tem sido associada, principalmente, à anormalidades hematológicas (Anderson et al., 1997).

\subsubsection{Anemia crônica}

O primeiro relato de anemia crônica associada ao B 19 ocorreu em 1987 (Kurtzman et al., 1987), envolvendo uma criança com síndrome de Nezelof (imunodeficiência congênita). Após esse relato, outros foram surgindo envolvendo pacientes com leucemia linfocítica aguda 
(Kurtzman et al., 1988) submetidos a transplante de medula (Weiland et al., 1989), transplante renal (Corral et al., 1993) e sob tratamento quimioterápico (Graeve et al., 1989).

O quadro infeccioso dos pacientes com anemia crônica é idêntico ao dos pacientes com AIDS. Devido ao comprometimento imunológico, o diagnóstico laboratorial somente é possível através da detecção do genoma viral (Weiland et al., 1989; Brown, 1997).

\subsubsection{Outras manifestações clínicas}

Após o reconhecimento do B19 como agente etiológico do eritema infeccioso e da TAC, outras patologias passaram a ser associadas a esse vírus, como, por exemplo, trombocitopenia (Uike et al., 1993), hidropsia fetal (Brown et al., 1984; 1994), manifestações neurológicas como meningites e encefalopatias (Nicle et al., 1999), vasculite sistêmica necrosante (Finkel et al., 1994), e conjuntivites (Yoshida e Tezuka, 1994).

\subsubsection{Diagnóstico laboratorial}

O diagnóstico laboratorial de infecção pelo vírus B19 é necessária, pois os sintomas clínicos são variáveis de pessoa para pessoa, e não-patogenomônicos, como no caso do eritema infeccioso que pode ser confundido com viroses de sintomatologias semelhantes tais como a rubéola e o sarampo (Cubel et al., 1997; Oliveira et al., 1998). Existe alta incidência de sarampo e rubéola no final do inverno e primavera, período em que se observa também a maior incidência de infeç̧ões pelo vírus B19 (Cubel et al., 1997). Além disso, o diagnóstico precoce pode direcionar o tratamento isto é de importância fundamental, principalmente nos casos de manifestações clínicas severas que colocam em risco a vida do paciente.

Assim, as descrições do envolvimento do B19 com inúmeras patologias incentivaram o aprimoramento das técnicas para deteç̧ão deste vírus. A infecção por B19 geralmente é diagnosticada por métodos sorológicos (Enders et al., 2006).

A partir de uma amostra clínica o diagnóstico laboratorial pode ser realizado por método direto, através da detecção de antígenos virais, DNA viral ou presença do vírus B19; ou indireto, onde se detecta a resposta imunológica do paciente contra o B19.

As primeiras técnicas utilizadas para detecção do vírus B19 foram a contraimunoeletroforese (CIE) e a imunomicroscopia eletrônica (IEM). Esses métodos, por apresentarem baixa sensibilidade, são eficazes apenas na fase inicial da infecção, quando o 
título viral é elevado (Caul et al., 1988; Knisely et al., 1988; Chrystie et al., 1990).

A utilização de sistemas de culturas celulares só permite o uso de células precursoras de eritrócitos como: células de medula óssea humana (Ozawa et al., 1986), do figado fetal (Yaegashi et al., 1989; Brown et al., 1991), do cordão umbilical (Srivastava et al., 1992) e células do sangue periférico humano (Serke et al., 1991). A obrigatoriedade do emprego dessas metodologias de culturas não convencionais torna o diagnóstico de rotina para o B19 pouco eficiente, não sendo possível a deteç̧ão de títulos virais baixos, devido o alto custo (Kurtzman et al., 1988).

Os anticorpos específicos das classes IgM e IgG, contra o B19, podem ser detectados através dos métodos de radioimunoensaio e ensaio imunoenzimático (Anderson et al., 1986; Kerr et al., 1996). Os testes que detectam anticorpos IgM específicos para o B19 são os mais usados para diagnosticar a infecção aguda em pacientes imunologicamente competentes (Fridel et al., 1991; Erdman et al., 1997). A presença de anticorpos do tipo IgG pode ser um indicador de infeç̧ão passada podendo, também, auxiliar no diagnóstico de infecção recente, caso seja observado um aumento significativo desses níveis quando colhida uma segunda amostra após o início da fase aguda da infecção (Palmer et al., 1996; Erdman et al., 1997).

As dificuldades diagnósticas aparecem nos casos de pacientes com infecção crônica pelo B19 e pacientes imunocomprometidos, nos quais baixos títulos virais podem persistir por meses ou, até, anos. Nesses casos, podem ser aplicados os métodos moleculares como a hibridização de DNA (Anderson et al., 1985; Clewley et al., 1989). Ainda, nestes pacientes imunologicamente debilitados, a aplicação da PCR (reação em cadeia pela polimerase) oferece alta sensibilidade para o diagnóstico e caracterização genética de B19 (Durigon et al., 1993; Holloway et al., 1993; Erdman et al., 1994).

\subsubsection{Proteínas VP1 e VP2 e sua aplicação diagnóstica}

VP1 e VP2 são as proteínas estruturais formadoras do capsídeo viral do B19, codificadas geneticamente pela mesma ORF a partir de diferentes pontos de iniciação (Figura 1). Diferenciam-se apenas na porção amino-terminal, sendo que VPl possui aminoácidos adicionais, em relação a VP2 (Berns, 1996). Essas proteínas podem ser utilizadas como antígenos para detecção imunológica de infecção por este vírus.

Nos vírus não-envelopados, as proteínas do capsídeo atuam funcionąlmente como ligantes de receptores. No caso do vírus B19, VP2 exerce esse papel (Browns et al., 1993). 
Estudos realizados para identificar epítopos neutralizantes no capsídeo do vírus B19 mostraram que a porção amino-terminal de VP1, que fica na parte externa do capsídeo, pode elicitar uma forte resposta imunológica. Além disso, os anticorpos contra o capsídeo são direcionados, predominantemente, para epítopos lineares dessa região (Rayment et al., 1990; Bansal et al., 1992; Saikawa et al., 1993). Ensaios de neutralização mostraram a importância dessa única região de VP1 que, também, estimula a formação de anticorpos neutralizantes para B19 (Bansal et al., 1992; Rosenfeld et al., 1992).

Segundo Heegaard e Brown (2002), é difícil a obtenção de antígenos de B19, decorrente do fato deste se replicar apenas em células precursoras. É possível cultivá-lo em células de medula das linhagens UT-7 e MB-2 de leucemia megacarioblástica (Munshi et al., 1993), porém, com a limitada disponibilidade dessas células e o baixo rendimento do vírus quando nelas cultivado, a produção de antígeno em larga escala torna-se inviável (Ozawa et al., 1987). O vírus B19 também pode ser obtido, em quantidade reduzida, a partir de soro de paciente em viremia ou propagado em tecido de figado fetal (Cohen e Bucley, 1988).

Essas dificuldades na obtenção de antígeno do B19 podem ser contornadas através da produção das proteínas VP1 e VP2 em sistemas de expressão de proteínas recombinantes em células procariotos ou eucariotas (Erdman et al., 1997). Não obstante, em tais sistemas existem diferenças na forma de obtenção dessas proteínas que são atribuídas aos ambientes e componentes celulares dos próprios sistemas de expressão (Makrides, 1996).

\subsection{Expressão de genes heterólogos em levedura}

Por serem organismos unicelulares, as leveduras apresentam as mesmas facilidades de manipulação e crescimento que as bactérias, porém com uma série de vantagens adicionais no que se refere à produção de proteínas heterólogas de origem eucarionte: ambiente intracelular favorável à correta formação de estruturas especiais e montagem das proteínas de eucariotos (Valenzuela et al., 1982); capacidade de processar modificações pós-traducionais, como glicosilação (Kukuruzinska et al., 1987), acilação (Towler et al., 1988) e fosforilação (Miyamoto et al., 1985) que contribuem para a manutenção da integridade estrutural, solubilidade, atividade biológica e localização celular das proteínas; bem como a capacidade de excreção eficiente, o que facilita a separação dos produtos recombinantes a partir meio de 
cultura.

A partir da primeira publicação referente à expressão de um gene heterólogo em Saccharomyces cerevisiae (Hitzemann et al., 1987) esse organismo tem sido largamente empregado como sistema hospedeiro (Romanos et al., 1992). Entre os motivos que levaram à esta situação, pode-se citar o fato de ser o eucarionte de genética e fisiologia melhor conhecidas. Há uma série de marcadores auxotróficos bem caracterizados, vários promotores fortes isolados, e um plasmídio natural $(2 \mu)$ estável mitoticamente. Por outro lado, é um organismo cuja natureza inofensiva à saúde é reconhecida desde tempos remotos, o que tem possibilitado o seu uso na produção de alimentos e bebidas.

Ainda, cabe ressaltar a utilização de leveduras para a produção de biomassa e seu uso na dieta humana e animal, pois este sistema oferece vantagens na produção e no valor nutritivo de alimentos, quando comparado com outras fontes de proteínas. Na Tabela 1 encontram-se os dados referentes à eficiência na produção de proteínas dos diferentes organismos, destacando-se, entre os microrganismos, a levedura, como uma importante alternativa para produção de proteínas, demonstrando-se, assim, o seu potencial.

Tabela 1 - Dados comparativos de eficiência de produção de proteína entre diferentes organismos, baseados na massa de 1 kilograma no tempo de 24 horas, a partir de massa inicial de 1 Kg.

\begin{tabular}{ll}
\hline \multicolumn{1}{c}{ Organismo $(1 \mathrm{~kg})$} & Quantidade de Proteína (24 h) \\
\hline Bife de carne bovina & $1,0 \mathrm{~kg}$ \\
Soja & $10,0 \mathrm{~kg}$ \\
Levedura & 100 toneladas \\
\hline
\end{tabular}

FONTE: U.S.D.A, 1976

Contudo, numerosas limitações têm surgido para uso deste organismo, especialmente no que se refere à adaptação dos processos de produção para uma escala industrial (Kingsman et al., 1987). Isto é devido principalmente ao estresse adicional provocado pela expressão dos genes clonados, o que ocasiona uma elevada instabilidade plasmidial, particularmente severa 
quando os produtos apresentam alguma toxidade para a célula. Outro resultado deste fenômeno é a redução da velocidade de crescimento, com conseqüentes perdas de produtividade. Uma das causas destes problemas é a fraca ou dificil regulação dos promotores selecionados para expressão, principalmente em cultivos realizados em biorreatores. Para minimizar estes efeitos, têm sido utilizados promotores induzíveis, de modo a conseguir uma separação parcial entre a fase de crescimento e a de formação do produto de interesse. Buscando solucionar o problema da instabilidade dos plasmídios de replicação autônoma, nosso grupo de pesquisa muito recentemente desenvolveu um sistema que permite múltiplas integrações do "cassete de expressão" desejado no genoma de $S$. cerevisiae (Guerra et al., 2006).

\subsection{Pichia pastoris}

\subsubsection{Histórico}

O uso da levedura Pichia pastoris como sistema de expressão de genes heterólogos é um caso típico de modelo interativo, onde se associam inovações dos tipos "technologypush" (onde descobertas na ciência básica levam a desenvolvimento tecnológicos industrias) e "need-pull" (onde as inovações surgem como resultado de uma demanda de mercado claramente articulada)(Hurtado, 1997).

O sistema de expressão em $P$. pastoris disponível foi desenvolvido pelo "Salk Institute of Biotechnology/Industrial Asssociates"(SIBIA), “joint venture" estabelecida em 1981 pela "Phillips Petroleum Company"(Bartlesville, OK - USA) com o "Salk Institute"(La Jolla, CA - USA). Esta associação surgiu depois da "Phillips Petroleum Co", concluir que a proteína unicelular produzida por $P$. pastoris, a partir de metanol, era incapaz de competir economicamente com a proteína de soja como ração animal. Procurou-se então aliar a tecnologia de processos fementativos, adquirida durante a década de 70 , com o potencial de emprego da região promotora do gene da álcool oxidase (Cereghino e Cereghino, 2000; Mcauley-Patrick et al., 2005).

No desenvolvimento deste sistema, a "Phillips Petroleum Co" optou, inicialmente, por uma extensiva manutenção do segredo de negócios para, uma vez dominado o conhecimento básico, assumir uma estratégia agressiva de obtenção de patentes. 
Depois de uma fase de incertezas quanto aos métodos de licenciamento mais adequados ao mercado em 1993 a "Phillips Petroleum Co" transferiu os direitos de exploração do sistema à "Research Corporation Technologies" (Tucson, AZ - USA). Atualmente, a "Invitrogen Corp. " (San Diego, CA - USA) está licenciada com exclusividade para elaborar e vender "kits" que podem ser empregados apenas para fins de pesquisa.

Como resultado da estratégia adotada em relação a este sistema, várias das patentes em vigor até agosto de 2007, cobriam métodos de transformação, seqüências de replicação autônomas regiões reguladoras para a expressão de genes heterólogos, marcadores de seleção, métodos de obtenção, recuperação e purificação de produtos específicos, entre outros de $P$. pastoris recombinantes.

\subsubsection{Expressão de gene heterólogos em $P$. pastoris}

A levedura $P$. pastoris é chamada de metilotrófica, devido a sua capacidade de metabolizar o metanol como fonte principal de carbono. $O$ primeiro passo no seu metabolismo é a oxidação do metanol para formaldeído, gerando peróxido. Esta reação é realizada dentro de uma organela especializada chamada peroxissomo. A enzima álcool oxidase possui baixa afinidade ao oxigênio, desta forma a levedura parece compensar esta deficiência sintetizando grandes quantidades da enzima (Figura 2) (Hartner et al., 2006).

A levedura $P$. pastoris apresenta duas características que a tornam uma atraente hospedeira para a produção de proteinas heterólogas. A primeira é o forte promotor usado para transcrever genes heterólogos, derivado do gene da álcool oxidase (AOX1). Para ser ativado, o promotor $A O X 1$ requer a presença de metanol, um indutor relativamente barato, $\mathrm{e}$, na ausência desse indutor, ele se torna reprimido. Em células expostas a metanol como única fonte de carbono, o início da transcrição a partir do promotor $A O X 1$ é altamente eficiente e comparável a dos promotores derivados dos genes altamente expressos da via glicolítica. No entanto, ao contrário dos promotores glicolíticos, o promotor $A O X 1$ é firmemente regulado e reprimido sob condições de crescimento sem metanol. Sendo que a maioria das proteínas heterólogas podem ser, de alguma forma, deletérias para a célula quando expressas em altos níveis, a habilidade de manter a expressão gênica reprimida ou desligada é altamente desejável. Trata-se também de uma importante precaução para minimizar a seleção de mutantes que não expressam o produto heterólogo desejado. Além da presença do metanol, o sistema $A O X 1$ necessita da ausência de glicose, para ser plenamente ativado. Uma vez que o 
promotor $A O X 1$ é regulado pela manipulação da fonte de carbono adicionada ao meio de cultura, o crescimento e a indução das proteínas recombinantes desejadas em $P$. pastoris podem ser facilmente controladas em todas as escalas, desde frascos agitados até biorreatores de grandes volumes (Boettner et al., 2002; Houard et al., 2002; Jungo et al., 2007a).

Em culturas realizadas sob agitação mecânica, o nível da enzima $A O X 1$ está em torno de $5 \%$ das proteínas solúveis totais, enquanto que pode chegar a $30 \%$, em culturas realizadas em biorreator (Higgins e Cregg, 1998).

O sistema $P$. pastoris tem sido usado para expressão de uma grande variabilidade de proteínas heterólogas (Cereghino e Cereghino, 2000). Desde 2002 tem ocorrido um aumento expressivo de processos que empregam a produção de proteínas recombinantes utilizando o sistema $P$. pastoris. Alguns desses dados estão descritos na Tabela 2. 


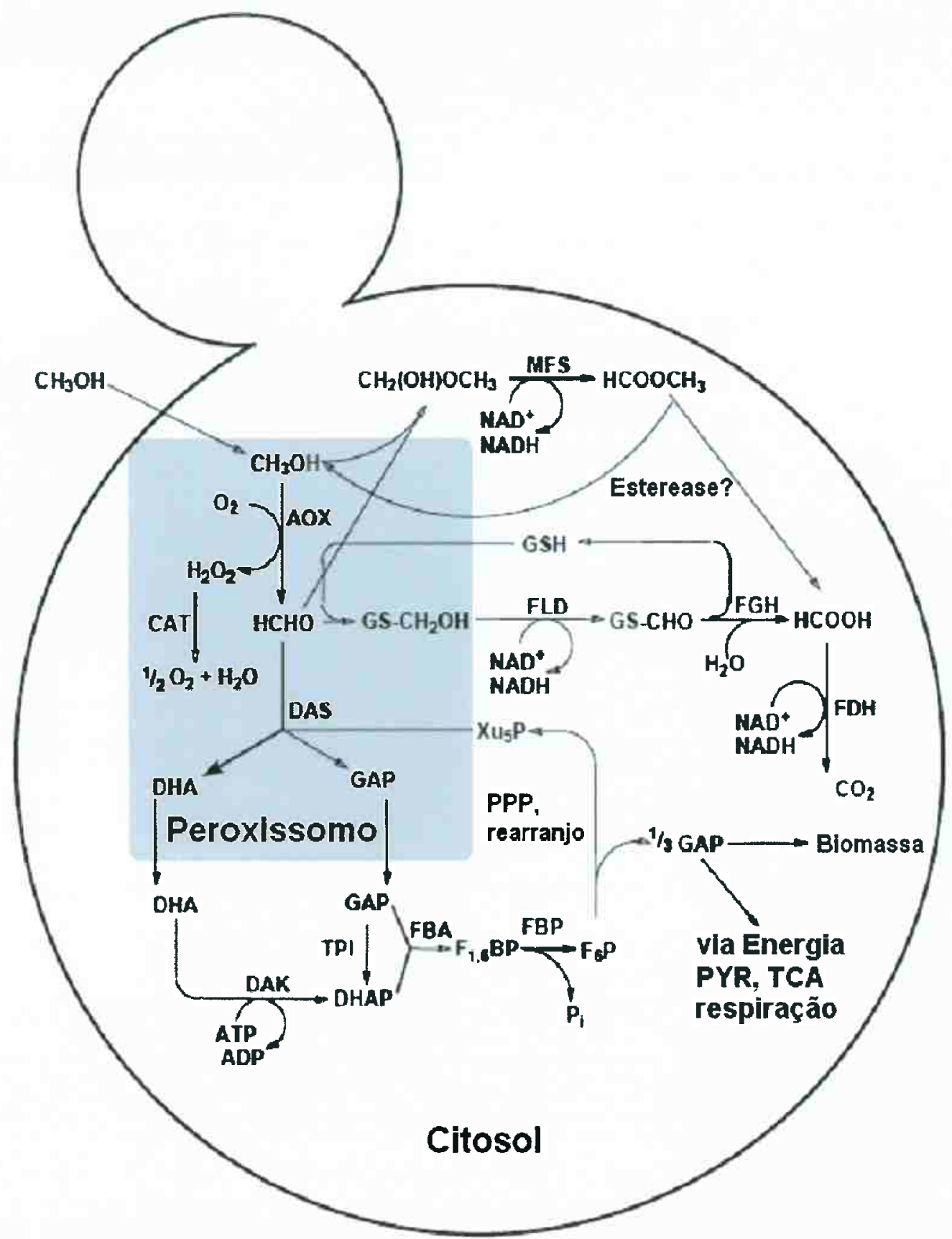

Figura 2 - Metabolismo do metanol ocorrido nas leveduras metilotróficas: As principais vias e as respectivas enzimas utilizadas. AOX: álcool oxidase, CAT: catalase, FLD: formaldeido desidrogenase, FGH: S-formilglutationa hidrolase, FDH: formato deidrogenase, DAS: diidroxiacetona sintase, TPI: tiosfosfato isomerase, DAK, diidroacetona quinase, FBA: futose 1,6-difosfato aldolase, FBP: futose 1,6-bisfosfato, MFS: metilfosfato sintase, DHA: diidroxiacetona, GAP: gliceraldeído 3-fosfato, DHAP: diidroxiacetona fosfato, $F_{1,6} B P$ : frutose 1,6-bisfosfato, $F_{6} P$ : frutose 6-fosfato, $P_{i}$ : fostato, $X_{u_{5}} P$ : xilose 5 -fosfato, GSH: glutationa, PYR: piruvato, PPP: pentose fosfato, TCA: ciclo de Krebs (extraido de Hartner et al., 2006). 
Tabela 2 - Exemplos de proteínas expressas em sistema P. pastoris (Macauley-Patrick et al., 2005).

\begin{tabular}{|c|c|c|}
\hline Proteina expressa/origem & Função & Nível de expressão \\
\hline \multicolumn{3}{|l|}{ Bactéria } \\
\hline $\begin{array}{c}\text { Clostridium botulinum } \mathrm{F} \\
{[\mathrm{BoNTF}(\mathrm{Hc}) \text { fragmento } \mathrm{C} \text { da }} \\
\text { cadeia pesada }\end{array}$ & antígeno & $205 \mathrm{mg} / \mathrm{kg}$ de célula \\
\hline \multicolumn{3}{|l|}{ Fungo } \\
\hline \multicolumn{3}{|l|}{ Invertebrado } \\
\hline \multicolumn{3}{|l|}{ L catepsina } \\
\hline \multicolumn{3}{|l|}{ Vertebrados } \\
\hline $\begin{array}{l}\text { Cadeia leve de enteroquinase } \\
\text { bovina }\left(\mathrm{EK}_{\mathrm{L}}\right)\end{array}$ & $\begin{array}{l}\text { Proteinase de serina } \\
\text { duodeno }\end{array}$ & $350 \mathrm{mg} / \mathrm{L}$ \\
\hline \multicolumn{3}{|l|}{ Humanos } \\
\hline $\begin{array}{l}\text { DNA topoisomerase I humana } \\
\text { (hTopo I) }\end{array}$ & $\begin{array}{c}\text { Transcrição e replicação } \\
\text { do DNA }\end{array}$ & $11-58 \mathrm{mg} / \mathrm{L}$ \\
\hline Fragmento FAB anti-HBS & $\begin{array}{l}\text { Prevenção e tratamento } \\
\text { do vírus da hepatite B }\end{array}$ & $50 \mathrm{mg} / \mathrm{L}$ \\
\hline \multicolumn{3}{|l|}{ Plantas } \\
\hline$\alpha$-Amilase de arroz (AmyIA/3D) & Hidrólise de amido & $340 \mathrm{mg} / \mathrm{L}$ \\
\hline $\begin{array}{l}\text { Gsp (Panax ginseng C. peptídio } \\
\text { medicinal) }\end{array}$ & $\begin{array}{l}\text { Usado como droga contra } \\
\text { diabetes }\end{array}$ & $800 \mathrm{mg} / \mathrm{L}$ \\
\hline $\begin{array}{l}\text { Vírus } \\
\text { nucleoproteína do vírus do } \\
\text { sarampo }(\mathrm{MeN})\end{array}$ & $\begin{array}{c}\text { Responsável pelo } \\
\text { empacotamento viral }\end{array}$ & $\begin{array}{c}29 \% \text { do total de } \\
\text { proteína }\end{array}$ \\
\hline
\end{tabular}


A levedura metilotrófica $P$. pastoris é vista como um dos sistemas mais promissores para a produção de altos níveis de proteínas heterólogas (Kobayashi, 2006; Hartner et al., 2006).

A produção em larga escala de proteínas heterólogas em frascos com agitação é dificultada pelas limitações de volume, transferência de oxigênio, adição de substrato e condições impróprias para monitorar estas variáveis (Macauley-Patrick et al., 2005). O uso de biorreatores é recomendável, pois todos esses parâmetros podem ser simultaneamente monitorados e controlados, possibilitando maior eficiência na produção da proteína heteróloga desejada (Cereghino et al., 2002).

Segundo Jungo et al $2007 \mathrm{~b}$, o processo para obtenção de altas densidades celulares de $P$. pastoris recombinantes deve ser conduzido em múltiplos estágios. O primeiro estágio é iniciado com crescimento da cultura em glicerol, alcançando-se níveis elevados da densidade celular e repressão do gene a ser expresso. O segundo estágio consiste na suplementação com concentrações mais elevadas de glicerol que a inicial, proporcionando a elevação dos níveis produção de biomassa e o bloqueio da expressão do promotor $A O X$. O último estágio envolve a indução e expressão da proteína recombinante, mediante suplementação em batelada de metanol (Figura 3).

A expressão de proteínas heterólogas no sistema $P$. pastoris compreende três passos principais: 1) Inserção do gene de interesse em um vetor de expressão; 2) Introdução do vetor de expressão em uma linhagem de $P$. pastoris; e, 3) Seleção da linhagem recombinante e avaliação do seu potencial de indução e expressão da proteína recombinante desejada (Macauley-Patrick et al., 2005). 


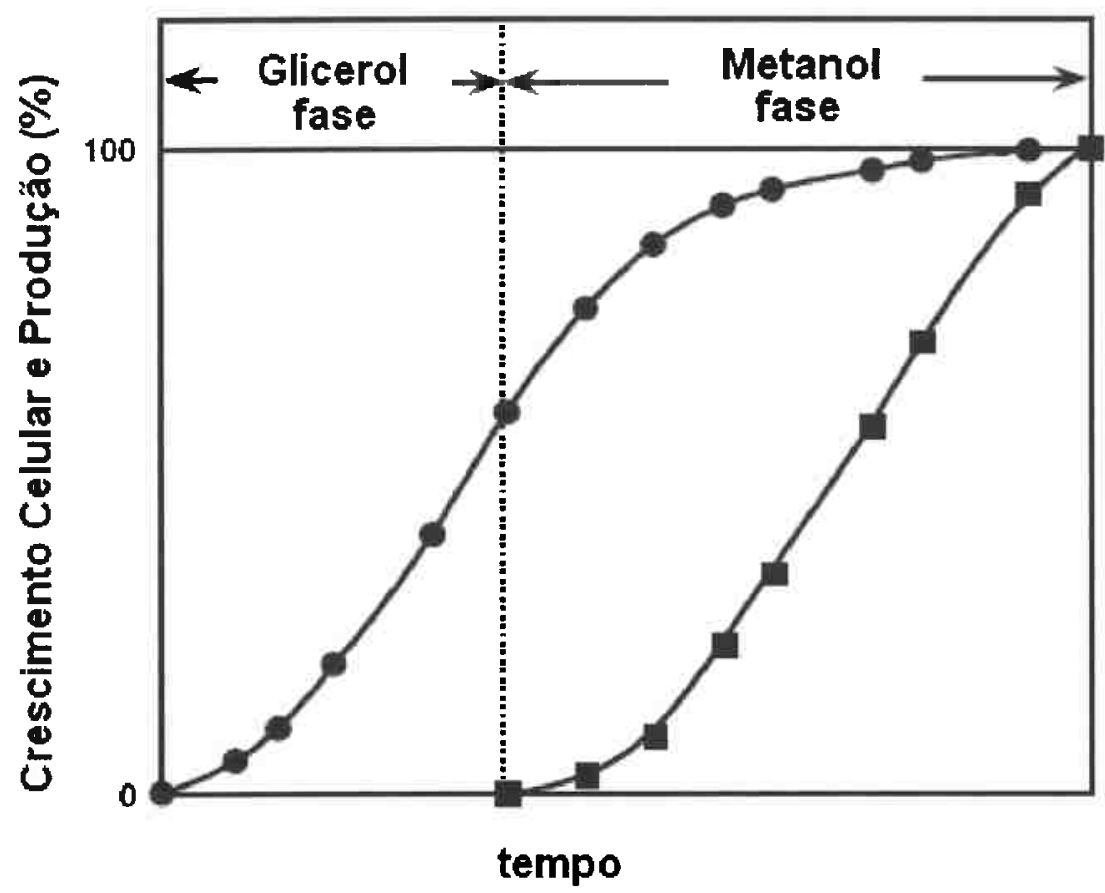

Figura 3 - Diagrama representativo do processo fermentativo na produção de proteínas heterólogas utilizando linhagens $P$. pastoris recombinantes. Crescimento celular (\%), $\square$ produção (\%) (Kobayashi, 2006).

\subsubsection{Vetores de clonagem e expressão}

As técnicas básicas necessárias para a construção de sistemas de expressão que empregam $P$. pastoris são geralmente similares àquelas usadas para construção de linhagens S. cerevisae recombinantes. Contudo, algumas diferenças existentes entre estes organismos exigiram o desenvolvimento de procedimentos específicos para o seu cultivo e manipulação. Desse modo, dado que $P$. pastoris não apresenta plasmídios naturais, os métodos para a transformação deste organismo baseiam-se no emprego de plasmídios replicativos ou na integração genômica da informação heteróloga.

Os vetores de clonagem e expressão pPIC9K e pHIL-D2 (Invitrogen®) (Figura 4A) são vetores bifuncionais ("shuttle vector") de $E$. coli e P. pastoris, com marcadores de seleção apropriados para cada um dos hospedeiros. O plasmídio pPIC9K possui seqüências do plasmídio pBR322, gene codificador da resistência à ampicilina $\left(A m p^{R}\right)$, origem de replicação (ColE1) e sítios para clonagem. Para seu emprego em $P$. pastoris, pPIC9K possui: o gene HIS4 de $P$. pastoris, que codifica a enzima histidinol desidrogenase (marcador para seleção de transformantes $\mathrm{His}^{+}$), possibilitando a complementação gênica da cepa GS115 (his4); a seqüência sinal de secreção do gene $\mathrm{MF}$ alfa de $S$. cerevisiae, para que ocorra a 
secreção da proteína heteróloga cujo gene codificador é clonado (Higgins e Cregg, 1998); e, o gene bacteriano codificador da resistência à kanamicina $\left(\operatorname{Kan}^{R}\right)$, que confere resistência ao antibiótico $\mathrm{G} 418^{\mathrm{R}}$, em $P$. pastoris.

$\mathrm{O}$ uso de vetores lineares para a transformação de $P$. pastoris resulta em transformantes estáveis, via recombinação homóloga entre seqüências do vetor de expressão e o genoma do hospedeiro. Após a inserção do gene desejado no múltiplo sítio de clonagem (MCS) dos vetores (pPIC9K ou pHILD2), os plasmídios recombinantes podem ser linearizados com SalI ou SacI. Estes fragmentos de DNA podem ser integrados no genoma de P. pastoris, por recombinação homóloga, no gene his4, ou na região $5^{1}$ do gene $A O X 1$, resultando no fenótipo $\mathrm{Mut}^{+}$(capacidade normal de metabolizar metanol)(Figura 4B e C). Outra possibilidade de trabalho consiste na clivagem do vetor recombinante derivado de pPIC9K, com a enzima $B g l \Pi$ ou do vetor pHIL-D2, com a enzima NotI. Quando a transformação de $P$. pastoris é feita com estes fragemntos, ocorre a substituição da região genômica entre $5^{\prime}$ e $3^{\prime}$ do gene $A O X 1$, resultando na deleção da região cromossomal codificante do gene $A O X 1$, que é substituída pelo cassete de expressão desejado. Os transformantes resultantes desta disrupção possuem fenótipo $\mathrm{Mut}^{\mathrm{s}}$ (crescimento lento em meio mínimo contendo metanol) (Figura 4D) (Cos et al., 2005).

Segundo Cós et al (2005), um fator que deve ser considerado para otimizar a expressão gênica homóloga é o fenótipo Mut. Para a expressão intracelular é preferível o uso de recombinantes $\mathrm{Mut}^{\mathrm{s}}$ porque as células aumentariam a quantidade de proteínas heterólogas (baixos níveis da proteína álcool oxidase). Para recombinantes que excretam a proteína recombinante, tanto o fenótipo $\mathrm{Mut}^{+}$ou $\mathrm{Mut}^{\mathrm{S}}$ podem ser usados.

$\mathrm{O}$ nível de resistência a $\mathrm{G} 418^{\mathrm{R}}$ depende do número de cópias do gene $\operatorname{Kan}^{R}$ integrados no genoma de $P$. pastoris. Assim, uma única cópia integrada confere resistência a aproximadamente, $0,25 \mathrm{mg} / \mathrm{mL}$ de $\mathrm{G} 418^{\mathrm{R}}$. Múltiplas cópias integradas conferem resistência a $\mathrm{G} 418^{\mathrm{R}}$ de $0,5 \mathrm{mg} / \mathrm{mL}$ (1-2 cópias), a $4 \mathrm{mg} / \mathrm{mL}$ (7-12 cópias). Devido ao fato da ligação genética entre o gene $\mathrm{G} 418^{\mathrm{R}}$ e o cassete de expressão, pode-se inferir que clones recombinantes de $P$. pastoris resistentes a altas concentrações de $\mathrm{G} 418^{\mathrm{R}}$ possuem também, múltiplas cópias do cassete de expressão de interesse integradas no genoma e, conseqüentemente, produzem maiores níveis de expressão da proteína recombinante desejada (Romanos et al., 1991; Cregg et al., 1993; Cos et al., 2005).

Convém ressaltar que, para transformação de $P$. pastoris, o vetor $\mathrm{pPIC} 9 \mathrm{~K}$ deve ser empregado como vetor integrativo. Assim, como já havia sido verificado em $S$. cerevisiae, 
plasmídios integrativos possuem freqüências de transformação muito baixas, de 1 a 10 transformantes/ $\mu \mathrm{g}$ DNA (Botstein e Davis, 1982; Ausubel et al., 1992; Sventina et al., 2000).

Um aspecto adicional que merece destaque, é o fato de que linhagens recombinantes de $P$. pastoris com alto número de cópias integradas no genoma, mostram-se extremamente estáveis, tanto durante a fase de crescimento quanto durante a etapa de indução de expressão dos genes clonados (Romanos et al., 1992).

Ainda cabe ressaltar que a levedura $P$. pastoris é também considerada pelo FDA americano, totalmente segura para humanos, tendo sido, reconhecida como "GRAS" ("Generally Recognized As Safe"), como já ocorre com $S$. cerevisae há muitos anos, (Sventina et al., 2000).

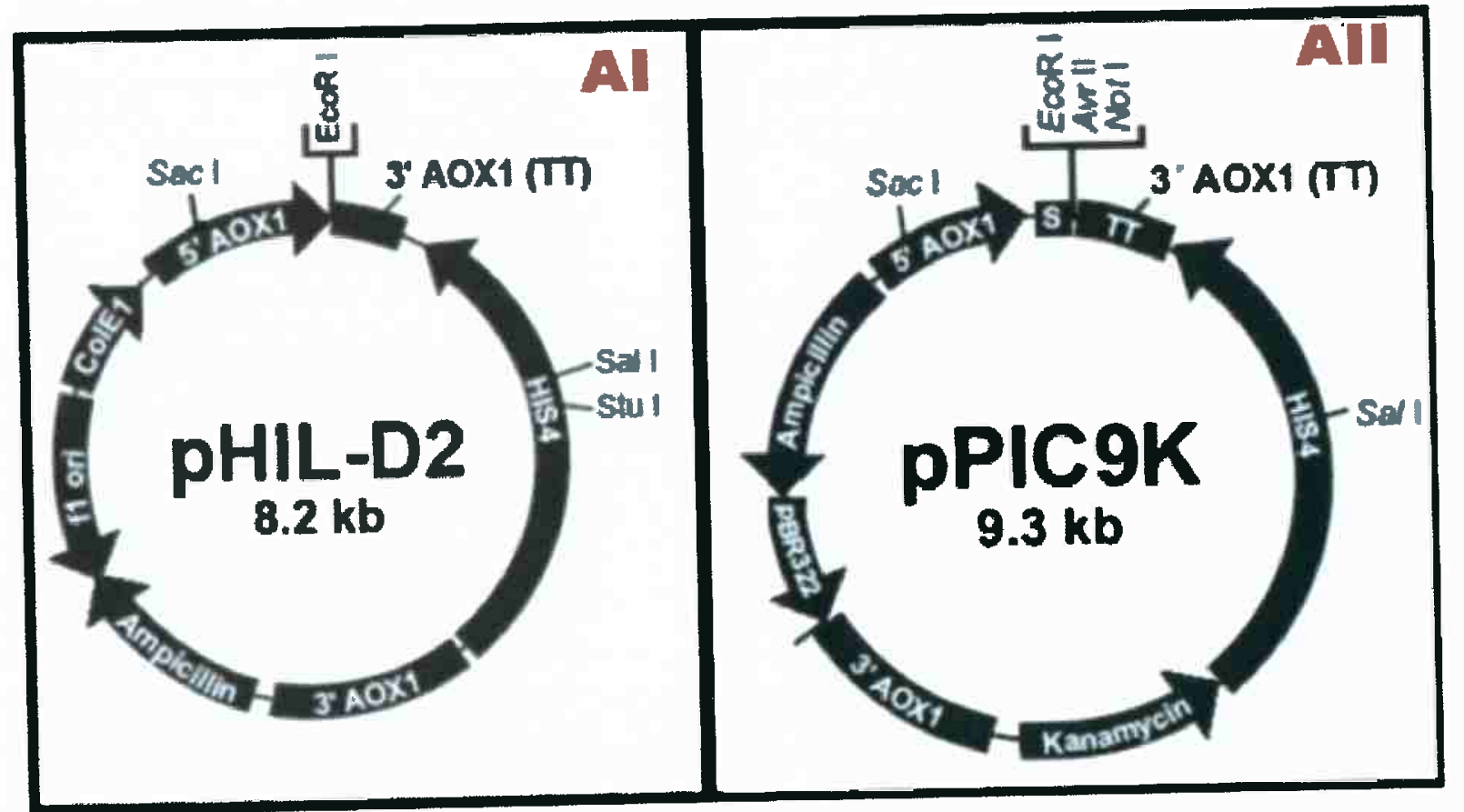

Figura 4A - Esquema dos plasmídios pHIL-D2 e pPIC9K (Invitrogen ${ }^{\circledR}$ ). AI - pHIL-D2 (8,2kb); AII pPIC9K $(9,3 \mathrm{~kb})$. 
: Inserção do vetor de transfolnação no gelle hist

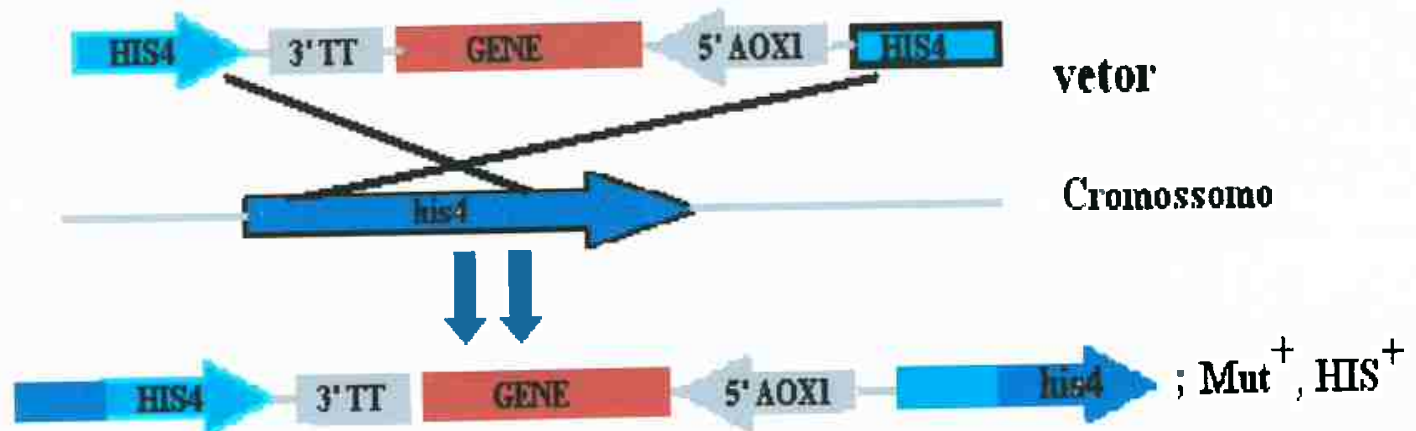

C Inserção do vetor de transformação no gene $A O X 1$

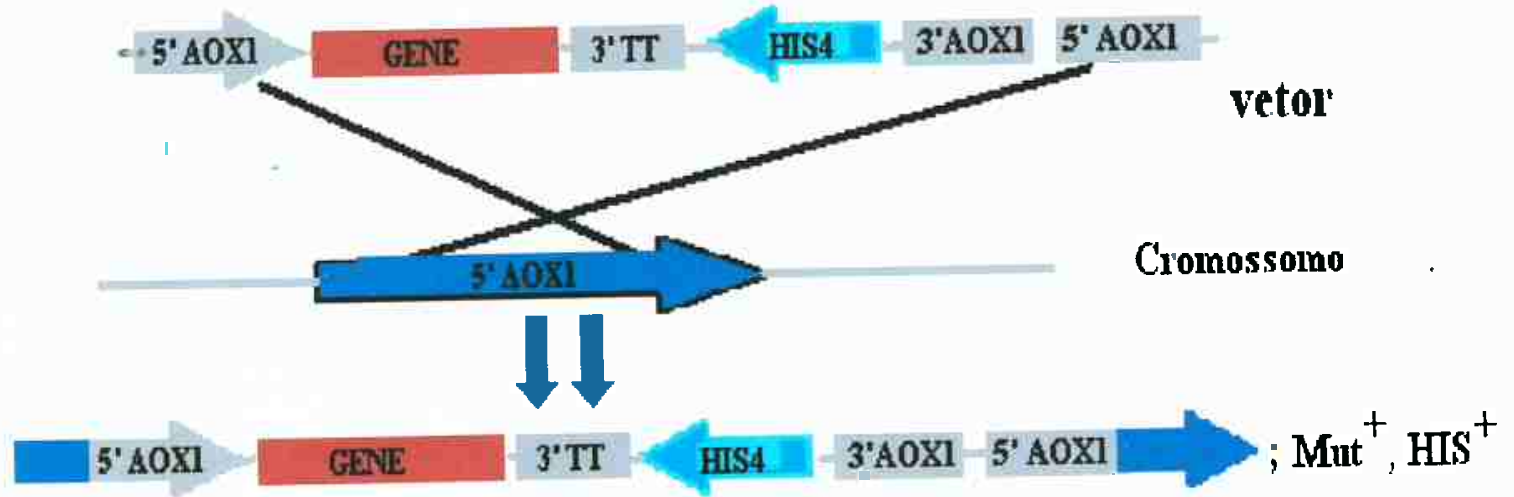

D Substituição do gene $A O X 1$ pelo vetor de transformação

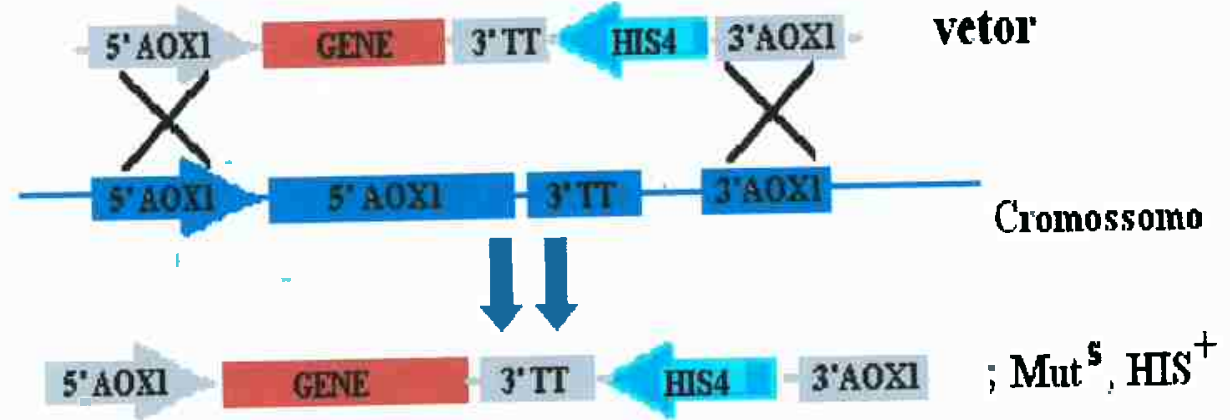

Figura 4B - Esquema de integração do vetor de transformação no genoma de Pichia pastoris: (B e C) mecanismo de integração por inserção, que gera transformantes $\mathrm{Mut}^{+}$; e (D) mecanismo de integração por substituição, que gera transformantes Mut ${ }^{s}$ (modificado de Daly et al., 2005). 


\section{OBJETIVOS}

O objetivo deste trabalho foi a construção de linhagens Pichia pastoris recombinantes capazes de expressar e excretar as proteínas antigênicas VP1 (84 kDA) e VP2 (58 kDa) do envoltório protéico do parvovírus humano B19, e realizar a caracterização destas proteínas recombinantes.

As etapas de trabalho foram:

Amplificação e clonagem dos fragmentos de DNA codificadores das proteínas VP1 e VP2 do vírus B19 em vetor intermediário pGEM-TEasy, visando a obtenção de concentrações elevadas destes fragmentos de DNA;

$\checkmark$ Clonagem dos fragmentos de DNA VP1 e VP2 em vetor de expressão excreção de $P$. pastoris pPIC9K;

$\checkmark \quad$ Expressão das proteínas recombinantes VP1 e VP2 em um volume de $100 \mathrm{~mL}$ de cultura em frascos erlenmeyer com haletas, sob agitação;

$\checkmark$ Caracterização das proteínas recombinantes VP1 e VP2 produzidas;

$\checkmark \quad$ Estudo do cultivo em biorreator de 4L das linhagens $P$. pastoris recombinantes; produtoras dos antígenos VP1 e VP2, visando a maximização da produção;

$\checkmark$ Extração e caracterização das proteínas VP1 e VP2 recombinantes produzidas;

$\checkmark$ Caracterização da atividade biológica das proteínas VP1 e VP2 recombinantes produzidas, empregando ensaios imunológicos. 


\section{MATERIAL E MÉTODOS}

\subsection{Linhagens de bactérias}

As linhagens utilizadas no trabalho são de origem laboratorial e encontram-se estocadas no Banco de Linhagens do Laboratório de Genética Molecular de Microrganismos do Departamento de Microbiologia do Instituto de Ciências Biomédicas da USP.

- Escherichia coli DH5a: supE44; $\Delta$ lacU169 (\$80 lacZ $\Delta \mathrm{M} 15) ;$ hsdR17 recA1; endA1; gyrA96; thi-1; relA1 (Sambrook e Russel, 2001).

\subsection{Levedura}

- Pichia pastoris: GS115 (Gregg et al., 1985; Invitrogen ${ }^{\circledR}$ CO., San Diego, CA-USA): Mutante his4, Fenótipo: His', Mut ${ }^{+}$,

- $P$. pastoris $\mathrm{G} 1$ 15/pPIC9K-VP1: família de clones recombinantes de $P$. pastoris que expressam excretam a proteína VP1 recombinante (construída neste trabalho);

- $P$. pastoris $\mathrm{G} 115 / \mathrm{pPIC} 9 \mathrm{~K}-\mathrm{VP} 2$ : família de clones recombinantes de $P$. pastoris que expressam excretam a proteína VP2 recombinante (construída neste trabalho); 


\subsection{Plasmídios}

Foram utilizados plasmídios, da coleção do Laboratório de Genética Molecular de Microrganismos do Instituto de Ciências Biomédicas da Universidade de São Paulo. Estes plasmídios encontram-se descritos na Tabela 3.

Tabela 3 - Lista dos plasmídios empregados neste trabalho.

\begin{tabular}{|c|c|c|}
\hline Plasmidio & Genótipo/fenótipo & Referência/origem \\
\hline $\begin{array}{l}\text { pGEM-TEasy, } 3,0 \mathrm{~Kb} \\
\text { (Figura } 8 \mathrm{~A} \text { e } 9 \mathrm{~A} \text { ) }\end{array}$ & $\begin{array}{l}\text { Vetor comercial adquirido para clonagem } \\
\text { de produto da PCR Amp }{ }^{R} \text {, lacZ }\end{array}$ & Promega $^{\circledR}$ \\
\hline $\begin{array}{l}\text { pGEM-TEasy-VP1, } \\
5,3,7 \mathrm{~Kb} \text { (Figura } 8 \text { ) }\end{array}$ & $\begin{array}{l}\text { Plasmídio recombinante derivado de } \\
\text { pGEM-TEasy que contem o Gene VP1 }\end{array}$ & Neste trabalho \\
\hline $\begin{array}{c}\text { pGEM-TEasy-VP2 } \\
4,7 \mathrm{~Kb} \text { (Figura 9) }\end{array}$ & $\begin{array}{l}\text { Plasmídio recombinante derivado de } \\
\text { pGEM-TEasy que contem o Gene VP2 }\end{array}$ & Neste trabalho \\
\hline $\begin{array}{l}\text { pPIC9K, 9,3 Kb, } \\
\text { (Figura 13B e 14B) }\end{array}$ & $\begin{array}{l}\text { Vetor comercial de clonagem adquirido } \\
\text { para expressão e excreção em } P \text {. pastoris } \\
\text { Amp }^{\mathrm{R}}, \mathrm{G} 418^{\mathrm{R}}, \mathrm{His}^{+}\end{array}$ & Invitrogen $^{(}$ \\
\hline $\begin{array}{l}\text { pPIC9K-VP1, } \\
11,6 \mathrm{~Kb} \text { (Figura 13) }\end{array}$ & $\begin{array}{l}\text { Plasmídio recombinante derivado de } \\
\text { pPIC9K que contem o Gene VP1 }\end{array}$ & Neste trabalho \\
\hline $\begin{array}{c}\text { pPIC9K-VP1, } \\
10,9 \mathrm{~Kb} \text { (Figura 14) }\end{array}$ & $\begin{array}{l}\text { Vetor de expressão } A m p^{\mathrm{R}}, \mathrm{G} 418^{\mathrm{R}} \text {, Gene } \\
\text { VP2 clonado em pPIC9K }\end{array}$ & Neste trabalho \\
\hline
\end{tabular}

Os plasmídios utilizados neste trabalho, foram estocados em bactéria $E$. coli DH5a, a - $80^{\circ} \mathrm{C}$. Essas culturas foram cultivadas em meio LB (descrito em matérias e métodos 3.4), com aeração por $16 \mathrm{~h}$; foram misturadas em igual proporção com uma solução de glicerol 40 $\%(\mathrm{p} / \mathrm{v})$, previamente esterilizada por autoclavação; misturadas e congeladas. Quando necessário, estes clones foram repicados em meio LB sólido contendo o antibiótico apropriado. 


\subsection{Meios de cultura para o cultivo de bactérias}

Para o cultivo de bactérias, foram empregados diversos meios completos (Sambrook e Russel, 2001). Para a elaboração dos meios sólidos foram acrescidos $2 \%$ de ágar aos meios líquidos correspondentes, Quando necessário, adicionou-se solução de ampicilina (fabricante Sigma ${ }^{\circledR}$ ) ao meio, numa concentração final de $100 \mu \mathrm{g} / \mathrm{ml}$. As bactérias semeadas em meio sólido, distribuídos em placas de Petri, foram incubadas em estufa a $37^{\circ} \mathrm{C}$, e o crescimento em meio líquido foi realizado com aeração em "shaker", a $150 \mathrm{rpm}$, na mesma temperatura. Todos os nutrientes empregados no preparo dos meios de cultura utilizados foram de procedência do fabricante $\operatorname{Difco}^{\circledR}$. Após o preparo todos os meios de cultura foram esterilizados em autoclave a $120^{\circ} \mathrm{C}$, por 20 minutos.

\subsubsection{Meio completo (Luria Bertani) - LB}

$1 \%$ triptona, $1 \%$ cloreto de sódio, $0,5 \%$ extrato de levedura.

\subsubsection{Meio de recuperação - SOC}

$2 \%$ triptona, $0,5 \%$ extrato de levedura, $10 \mathrm{mM}$ de cloreto de magnésio, $10 \mathrm{mM}$ sulfato de magnésio, $20 \mathrm{mM}$ glicose.

\subsection{Meios de cultura para o cultivo de levedura}

Para o cultivo de leveduras, foram empregados diversos meios de cultura (Sambrook e Russel, 2001), para elaboração dos meios sólidos, foram acrescidos $2 \%$ de ágar aos meios líquidos correspondentes. As leveduras semeadas em meio sólido, distribuídos em placas de Petri, foram incubadas em estufa a $28^{\circ} \mathrm{C}$, e o crescimento em meio líquido foi realizado com aeração com agitação, $150 \mathrm{rpm}$, na mesma temperatura. Todos os nutrientes empregados no preparo dos meios de cultura utilizados foram de procedência do fabricante Difco ${ }^{\circledR}$. Após o preparo, os meios de cultura foram esterilizados em autoclave a $120{ }^{\circ} \mathrm{C}$, por 20 minutos. Os sais utilizados foram de grau bacteriológico do fabricante MERCK ${ }^{\circledR}$. 
3.5.1 Meio mínimo - MD

$1,34 \%$ "yeast nitrogen base with amino acids", $4 \times 10^{-5} \%$ Biotina, $2 \%$ de glicose.

\subsubsection{Meio completo - YP}

$1 \%$ extrato de levedura, $2 \%$ peptona.

3.5.3 Meio completo acrescido de glicose - YPD

Meio YP, $2 \%$ de glicose.

3.5.4 Meio completo acrescido de metanol - YPM

Meio YP, $0,5 \%$ de metanol.

3.5.5 Meio completo acrescido de glicerol - YPG

Meio YP, $1 \%$ de glicerol.

3.5.6 Meio completo acrescido de glicose e antibiótico geneticina $\mathrm{G} 418^{\mathrm{R}}$ YPD-G418

Meio YPD, acrescido com antibiótico geneticina $G 418^{R}$ na concentração entre $0,5-4$ $\mathrm{mg} / \mathrm{mL}$.

\subsubsection{Meio FM22}

$42,9 \mathrm{~g} \mathrm{KH}_{2} \mathrm{PO}_{4} ; 5 \mathrm{~g}\left(\mathrm{NH}_{4}\right) \mathrm{SO}_{4} ; 1,0 \mathrm{~g} \mathrm{CaSO}_{4} .2 \mathrm{H}_{2} \mathrm{O} ; 14,3 \mathrm{~g} \mathrm{~K}_{2} \mathrm{SO}_{4} ; 11,7 \mathrm{~g} \mathrm{MgSO}_{4} .7 \mathrm{H}_{2} \mathrm{O}$; $40 \mathrm{~g}$ glicerol; volume final de $1 \mathrm{~L}$.

$\mathrm{O} \mathrm{pH}$ foi ajustado para 4,5 com KOH e em seguida, foi adicionado $1 \mathrm{~mL}$ da solução de sais PMT4. 


\subsection{Soluções}

Para o preparo das soluções, foram utilizados reagentes de pureza analítica e água bidestilada. Todas as soluções foram esterilizadas a $120^{\circ} \mathrm{C}$, durante 20 minutos e, quando necessário, foram filtradas em membrana do tipo esterilizante de poro $0,22 \mu \mathrm{m}$. Exceto quando indicado especificamente, todas as soluções foram preparadas de acordo com Sambrook e Russel, 2001.

\subsubsection{Solução I}

$25 \mathrm{mM}$ Tris- $\mathrm{HCl}, 10 \mathrm{mM}$ EDTA, 50mM Glicose, $\mathrm{pH} \mathrm{8,0.}$

\subsubsection{Solução II}

0,2 M Hidróxido de Sódio, 1\% SDS.

\subsubsection{Solução III}

3 M Acetato de Sódio, 2 M Ácido Acético, pH 4,8.

\subsubsection{Solução de RNase A}

$10 \mathrm{mg} / \mathrm{mL}$ em $\mathrm{NaOH} 0,1 \mathrm{M}$.

\subsubsection{Acetato de lítio $1 \mathrm{M}$}

$10,2 \mathrm{~g} / 100 \mathrm{~mL}$ de água destilada. A solução foi esterilizada por filtração.

\subsubsection{LTE}

Acetato de lítio 0,1 M; Tris $\mathrm{HCl}$ 0,01 M e EDTA $1 \mathrm{mM}$. Esta solução foi sempre esterilizada por filtração, com filtro $0,22 \mu \mathrm{m}$ (Gietz et al., 1992).

\subsubsection{Solução salina}

$0,85 \% \mathrm{NaCl}$ em água destilada.

\subsubsection{Solução estoque de brometo de etídeo - "EB":}

$5 \mathrm{mg}$ de EB em $50 \mathrm{~mL}$ de água destilada. Esta solução não foi esterilizada. 
3.6.9 Solução de glicose a $50 \%$

$50 \mathrm{~g}$ de glicose em $100 \mathrm{~mL}$ de água destilada, fervida e autoclavada.

3.6.10 Solução clorofórmio-álcool isoamílico:

24 volumes de clorofórmio para 1 volume de álcool isoamílico.

3.6.11 Solução fenol-clorofórmio

1 volume de fenol para 1 volume de clorofórmio. Esta solução não foi esterilizada.

3.6.12 Solução desnaturante

$0,5 \mathrm{M} \mathrm{NaOH}, 1,5 \mathrm{M} \mathrm{NaCl}$.

3.6.13 Solução neutralizante

$0,5 \mathrm{M}$ Tris- $\mathrm{HCl}(\mathrm{pH} 7,5), 1,5 \mathrm{M} \mathrm{NaCl}$.

3.6.14. TE

$20 \mathrm{mM}$ Tris- $\mathrm{HCl} \mathrm{pH}$ 8,0 e 20mM EDTA pH 8,0

\subsubsection{TBE $10 \mathrm{X}$}

0,89 mM Tris; $0,89 \mathrm{mM}$ ácido bórico e $0,2 \mathrm{mM}$ EDTA.

3.6.16 Tampão de corrida para eletroforese em gel de agarose - TBE 0,5X Tampão TBE 10X, diluído 20X.

3.6.17 Tampão de amostra "Stop Mix" - 10X

Azul de Bromofenol 0,5\%; glicerol 50\% e EDTA 100 mM (pH 8,0).

3.6.18 Tampão fosfato salino (PBS)

$\mathrm{NaCl}-8,0 \mathrm{~g}$; $\mathrm{KCl}-0,2 \mathrm{~g} ; \mathrm{Na}_{2} \mathrm{HPO}_{4}$. $2 \mathrm{H}_{2} \mathrm{O}-1,4 \mathrm{~g}$; $\mathrm{KH}_{2} \mathrm{PO}_{4}-0,2 \mathrm{~g}$ 


\subsubsection{Solução de sais de PMT4}

$2,0 \mathrm{~g} \mathrm{CuSO} \mathrm{H}_{4} \mathrm{H} \mathrm{O} ; 0,08 \mathrm{~g} \mathrm{NaI} ; 3,0 \mathrm{~g} \mathrm{MnSO}_{4} .5 \mathrm{H}_{2} \mathrm{O} ; 0,2 \mathrm{~g} \mathrm{Na} 2 \mathrm{MoO}_{4} .2 \mathrm{H}_{2} \mathrm{O} ; 0,02 \mathrm{~g}$ $\mathrm{H}_{3} \mathrm{BO}_{3} ; 0,5 \mathrm{~g} \mathrm{CaSO}_{4} .2 \mathrm{H}_{2} \mathrm{O} ; 0,5 \mathrm{~g} \mathrm{CoCl}_{2} ; \mathrm{g} \mathrm{ZnCl}_{2} ; 22 \mathrm{~g} \mathrm{FeSO}_{4} .7 \mathrm{H}_{2} \mathrm{O} ; 0,2 \mathrm{~g}$ biotina; $1 \mathrm{~mL} / \mathrm{L}$ de $\mathrm{H}_{2} \mathrm{SO}_{4}$ concentrado; para um volume final de $1 \mathrm{~L}$. Esta solução foi esterilizada por filtração.

Para as alimentações em batelada no biorreator, adicionou-se $4 \mathrm{~mL}$ de PMT4 a $1 \mathrm{~L}$ de glicerol 40\%, e $6 \mathrm{~mL}$ para 1 litro de metanol 100\%.

\subsection{Obtenção das Sequênciais gênicas VP1 e VP2}

\subsubsection{Estudo das seqüências VP1 e VP2}

Os genes de interesse foram analisados com os "softwares" "MegAlign.Ink, EditSeq, PrimerSelect" (v. 5.03 - DNASTAR, licenciados para o Departamento de Microbiologia do Instituto de Ciências Biomédicas -USP) para encontrar os sítios de restrição presentes na seqüência, a possibilidade de formação de dímeros ou de grampos (autocomplementariedade), para o cálculo da temperatura de dissociação das estruturas.

Os pares de "primers" (Forward e Reverse) foram, desenhados de forma a evitar a formação de estruturas indesejáveis, de modo a terem temperaturas de anelamento mais próximas possiveis umas das outras. As seqüências dos "primers" encontram-se descritas na Tabela 4, onde está destacado em negrito o sítio de restrição no "primer" incluído no amplicon. Sublinhadas estão as seqüências complementares dos genes VP1 e VP2 do parvovírus humano B19 (disponivel no Genbank).

As seqüências dos "primers" foram reavaliadas pelo programa BLAST (http://www.ncbi.nlm.nih.gov/cgi-bin/BLAST), a fim de confirmar a identidade com as seqüências dos genes VP1 e VP2 do vírus B19.

\subsubsection{Obtenção de amostra clínica com DNA viral positivo para B19}

As amostras clínicas de soro de pacientes com diagnóstico clínico e laboratorial de infecção pelo B19, foram provenientes do Laboratório de Virologia Clínica Molecular do Instituto de Ciências Biomédicas da Universidade de São Paulo. 
O diagnóstico laboratorial foi baseado na detecção de anticorpos IgM e IgG para o parvovírus B19 pelo método de ELISA de captura e deteç̧ão direta do DNA viral, pela técnica da PCR (Reação em Cadeia pela Polimerase) (Vicari, 2002). Essas amostras foram extraídas obedecendo-se as exigências de bioéticas pertinentes ao estudo.

\subsubsection{Obtenção dos fragmentos de DNA codificadores dos genes VP1 e VP2}

Para obtenção dos fragmentos de DNA codificadores dos genes estruturais que codificam as proteínas VP1 $(2,3 \mathrm{~Kb})$ e VP2 $(1,6 \mathrm{~Kb})$ (Durigon et al., 1993), foi realizada a reação de amplificação por PCR, empregando-se como molde o DNA viral positivo para B19. Os "primers" utilizados nessas reações foram sintetizados pela Invitrogen ${ }^{\circledR}$. Para o desenho dos “primers" Pv1, Pv2 e Pvr, foram incluídas seqüências de 27 a 28 nucleotídeos complementares das extremidades $5^{\prime}$ e $3^{\prime}$ de cada um dos genes. Os sítios de restrição para as enzimas EcoRI e NotI foram adicionados à extremidade $5^{\prime}$ das seqüências, de forma a permitir a clonagem em vetor pPIC9K sem interferir no quadro de leitura dos genes.

O "primer" Ps foi desenhado, com o objetivo de verificar a correta ligação dos insertos VP1 e VP2 com vetor de clonagem pPIC9K, e a fase de leitura.

Os "primers" utilizados para amplificação do genes codificadores de VP1 e VP2 por PCR, visando a clonagem ou o sequenciamento destes fragmentos de DNA encontram-se descritos na Tabela 4.

A estratégica adotada para os sequenciamentos está melhor detalhada na Figura 5. 
Tabela 4 - Seqüência dos "primers" utilizados para a realização da PCR para amplificação e análise dos genes VP1 e VP2 vírus B19.

\begin{tabular}{|c|c|c|c|}
\hline Primer & Posição & Seqüência $\left(5^{\prime}-3^{\prime}\right)$ & Referência \\
\hline Pv1 & $2444-2472$ & $\begin{array}{l}\text { CGGAATTCATGAGTAAAAAAAG } \\
\text { TGGC AAATGGTGGG }\end{array}$ & Neste trabalho \\
\hline Pv2 & $3125-3155$ & $\begin{array}{l}\text { CGGAATTCATGACTTCAGTTAA } \\
\text { TTCTGCAGAAGCCAGC }\end{array}$ & Neste trabalho \\
\hline Pvr & $4787-4760$ & $\begin{array}{l}\text { ATAAGAATGCGGCCGCTCACA } \\
\text { ATGGGTGCACACGGCTTTTGGC }\end{array}$ & Neste trabalho \\
\hline Pr & $2925-2901$ & GCCAGTTGGCTATACCTAAAG & $\begin{array}{l}\text { Durigon et al., } 1993 \\
\text { Erdman et al., } 1996\end{array}$ \\
\hline P7f & $3142-3163$ & TGCAGAAGCCAGCACTGGTGC & $\begin{array}{l}\text { Durigon et al., } 1993 \\
\text { Erdman et al., } 1996\end{array}$ \\
\hline P10f & $3567-3589$ & GCCTATGCATGTTAGTAGACC & $\begin{array}{l}\text { Durigon et al., } 1993 \\
\text { Erdman et al., } 1996\end{array}$ \\
\hline $\mathrm{P} 14 \mathrm{r}$ & $3868-3845$ & CACTCCTTGCTGATACTCTT & $\begin{array}{l}\text { Durigon et al., } 1993 \\
\text { Erdman et al., } 1996\end{array}$ \\
\hline P19r & $4237-4214$ & GTGTTGACTGCAGCCCTCTAA & $\begin{array}{l}\text { Durigon et al., } 1993 \\
\text { Erdman et al., } 1996\end{array}$ \\
\hline Ps & $1108-1128$ & GCCATTTTCCAACAGCACAA & Neste trabalho \\
\hline
\end{tabular}




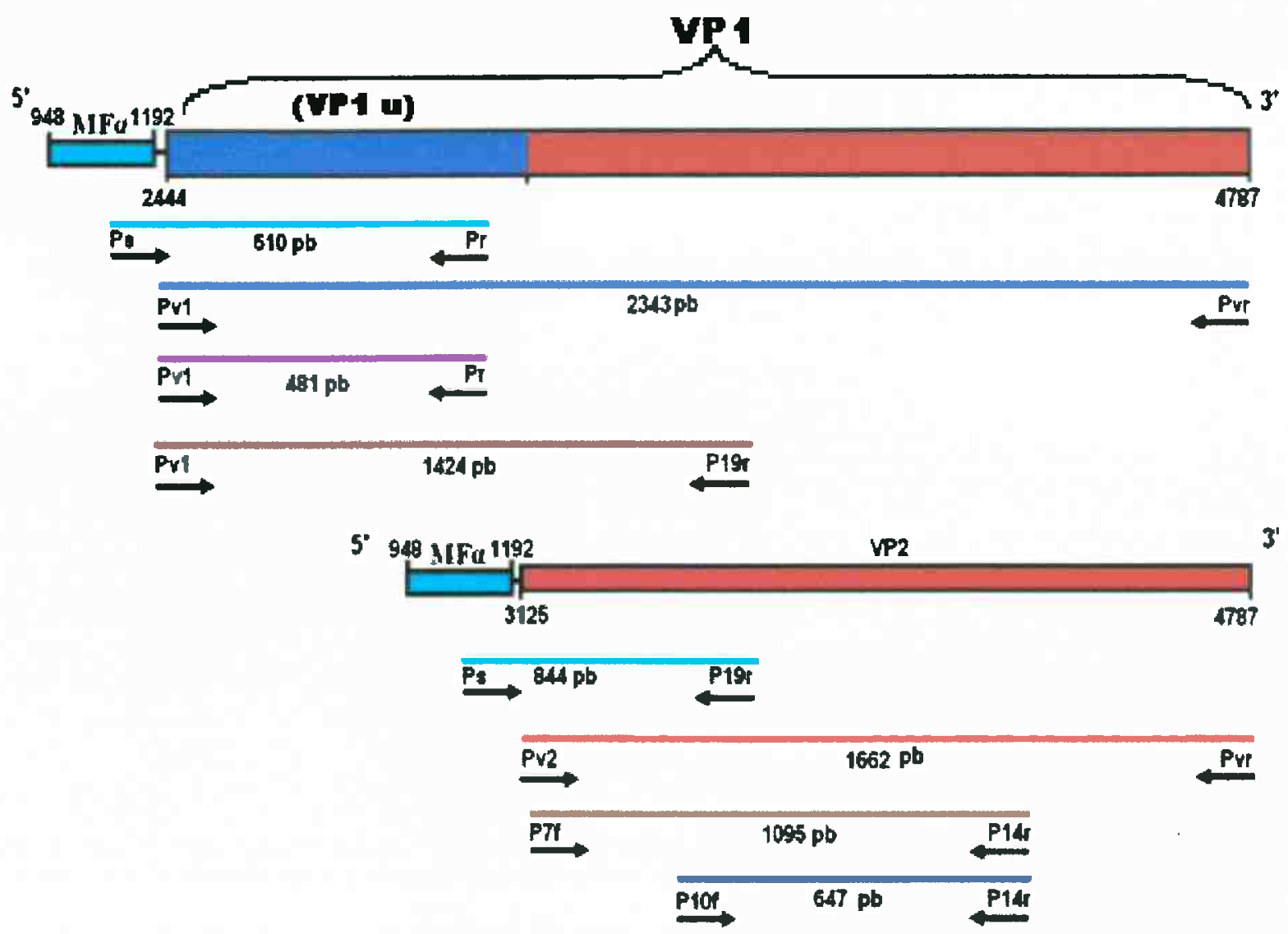

Figura 5 - Esquema de anelamento dos "primers" utilizados na amplificação dos genes que codificam as proteínas VP1 e VP2 do vírus B19.

No programa da PCR, foram utilizados os ciclos; a) $94{ }^{\circ} \mathrm{C}$, por 5 minutos (realizado uma vez): b) $95{ }^{\circ} \mathrm{C}, 45$ segundos (desnaturação); $55{ }^{\circ} \mathrm{C}, 60$ segundos (anelamento dos oligonucleotídeos); $72{ }^{\circ} \mathrm{C}, 90$ segundos (extensão) 40 ciclos; e no final um único ciclo de 72 ${ }^{\circ} \mathrm{C}$, por 7 minutos (para realizar todas as extensões incompletas). Após a amplificação por PCR, os produtos obtidos foram analisados em gel de agarose $0,7 \%$.

Os reagentes empregados nas reações, assim como a enzima Taq Polimerase, foram provenientes do fabricante "Invitrogen ${ }^{\bigotimes}$ ". As reações de amplificação foram realizadas de acordo com as indicações do fabricante da enzima Taq Polimerase. O Termociclador utilizado foi o "DNA Engine" do fabricante "MJ Research", modelo "PTC-200 Peltier Thermal Cycler". 


\subsection{Purificação dos produtos da PCR}

Os fragmentos de DNA obtidos por amplificação por PCR foram submetidos a corrida eletroforética em gel de agarose $0,7 \%$, e purificados usando o protocolo descrito em Material e Métodos, item 3.13.

\subsection{Sequenciamento dos genes codificadores de VP1 e VP2 clonados nos plasmídios recombinantes pPIC9K-VP1 e pPIC9K-VP2}

A reação de sequenciamento foi realizada utilizando os "primers" descrito na Tabela 4, com o kit "ABI PRISM Dye ${ }^{\mathrm{TM}}$ Terminator Cycle Sequencing Ready Reaction /dt (Big Dye v3.1 Applied biosystems ${ }^{\mathbb{Q}}$ )", seguindo instruções do fabricante.

Cerca de 10-30 ng de produto de PCR purificados, foram adicionados a um microtubo acrescido de $2 \mu \mathrm{L}$ de Tampão "Save Money" $5 \mathrm{X}$ (Tris HCI 200mM pH 9,0 e $5 \mathrm{mM} \mathrm{MgCl}_{2}$ ), $3.2 \mathrm{pMol}$ do "primer", $2 \mu \mathrm{L}$ do kit ABI PRISM Dye ${ }^{\mathrm{TM}}$ Terminatar Cycle Sequencing Ready Reaction kit (Big Dye v3.1 Applied biosystems®) e água ultra pura para completar um volume final de $10 \mu \mathrm{L}$. Este procedimento foi efetuado separadamente para cada um dos "primers".

A reação foi realizada em termociclador "MasterCycler gradient (Eppendor $f^{\circledR}$ )" a partir de uma etapa de $96^{\circ} \mathrm{C}$ por 1 segundo, seguidos de 25 ciclos de $96^{\circ} \mathrm{C}$, por 15 segundos, para a denaturação do DNA molde, $50{ }^{\circ} \mathrm{C}$ por 15 segundos, para o emparelhamento dos "primers" e $60^{\circ} \mathrm{C}$, por 4 minutos, para a extensão.

\subsubsection{Purificação}

O produto obtido foi purificado, visando a remoção de excesso de dideoxinucleotídeos "terminadores" presentes na reação, por precipitação com isopropanol, descrita a seguir:

Ao produto da reação de sequenciamento foram adicionados $30 \mu \mathrm{L}$ de água ultra pura e $60 \mu \mathrm{L}$ de isopropanol a 100\%, agitados em "vortex" e submetido a centrifugação, por 60 
minutos, a $4.000 \mathrm{~g}$ a temperatura ambiente. Foi utilizada a centrifuga "(Centrifuge 5804R Eppendorf ${ }^{8}$ )". O sobrenadante foi descartado e em seguida foi adicionado $250 \mu \mathrm{L}$ de etanol $70 \%$, agitados em "vortex" e nova centrifugação por 30 minutos, a $4000 \mathrm{~g}$, a temperatura ambiente.

As amostras de DNA foram purificadas, precipitadas; ressuspensas em $10 \mu \mathrm{L}$ de formamida ultra pura (formamida Hi-Di - "Applied Biosystems ${ }^{(B)}$ )"; denaturadas a $95{ }^{\circ} \mathrm{C}$, por $3 \mathrm{~min}$; e resfriadas em banho de gelo por mais 2 min e então submetidas à eletroforese em polímero POP6 "(Applied Biosystems", utilizando seqüênciador automático ABI-PRISM modelo 3100 "(Applied Biosystems ${ }^{\text {(\$)". }}$ ". As amostras foram traqueadas automaticamente utilizando software do Analisador Automático de DNA ABI Prism ${ }^{\circledR}$ modelo 3100.

\subsubsection{Processamento e alinhamento das seqüências codificadoras de VP1 e VP2 do B19}

As seqüências de nucleotídeos foram analisadas com o programa "SeqMen ${ }^{\mathrm{TM}}$ II Expert Analysis Software" - DNASTAR, Inc., EUA, para obtenção de dois segmentos de aproximadamente 3245 e 1662 nucleotídeos correspondentes aos genes codificadores das proteínas virais do vírus B19 VP1 e VP2, respectivamente.

Posteriormente, essas seqüências foram traduzidas, utilizando-se o programa "Edit $\mathrm{Seq}^{\mathrm{TM}} 5,03$-Expert Analysis software" - DNASTAR Inc para PC.

A seqüências de nucleotídeos e aminoácidos foram alinhadas, juntamente com seqüências adquiridas do GenBank (utilizando o programa "Meg Align" ${ }^{\mathrm{TM}}$ 5,03 - Expert Analysis Software" - DNASTAR, Inc., EUA. Os arquivos correspondentes aos fragmentos amplificados pelos "primers" internos, foram analisados separadamente com o referido programa, tendo como resultado a obtenção do grau de similaridade entre as seqüências, calculadas par a par, o que possibilitou a identificação das sequiências de nucleotídeos idênticas e divergentes. 


\subsection{Extração de DNA plasmidial de bactéria}

As extrações de plasmídios de Escherichia coli foram realizadas a partir de culturas com $3 \mathrm{~mL}$ ("mini-prep") ou com $50 \mathrm{~mL}$ ("midi-prep"), de acordo com Sambrook e Russel, 2001.

\subsection{Tratamento de DNA plasmidial com enzimas de restrição}

Foram realizados misturas de digestão com volumes finais entre 10 a $50 \mu \mathrm{L}$, sempre empregando o tampão de reação apropriado e as condições de incubação e temperatura recomendadas pelo fabricante. A quantidade de DNA utilizada nas digestões variou de acordo com o experimento. Sempre foi utilizado entre 1 a $2 \mathrm{U}$ de enzima para cada $\mu \mathrm{g}$ de DNA. Os tempos de incubação variaram de 2 a 5 horas e, ocasionalmente, durante a noite. As enzimas de restrição e outras enzimas, especiais empregadas na manipulação de DNA foram adquiridas das empresas Amersham ${ }^{\circledR}$, Fermentas $^{\circledR}$, Invitrogen ${ }^{\circledR}$, New England Biolabs $^{\circledR}$, Pharmacia ${ }^{\circledR}$, Promega ${ }^{\circledR}$. Todas as enzimas foram utilizadas com seus tampões específicos e de acordo com os protocolos enviados pelos fabricantes.

\subsection{Análise dos fragmentos de DNA em gel de agarose}

Foram realizadas análises dos perfis de migração dos fragmentos de DNAs em géis de agarose submetidos a corridas eletroforéticas, sempre que se desejava analisar a sua pureza ou tamanho. Empregou-se géis de agarose Sigma "Ultra Pure" 0,8\%, em tampão TBE 0,5X e $0,5 \mu \mathrm{g} / \mathrm{ml}$ de brometo de etídio. As corridas eletroforéticas foram realizadas com tampão de corrida TBE 0,5X (Sambrook e Russel, 2001). A visualização das bandas e a fotodocumentação foram realizadas empregando-se um transluminador contendo lâmpada ultra-violeta, e o aparelho "Eagle-eye" da "Stratagene", modelo "EAGLE EYE II". 


\subsection{Purificação dos fragmentos de DNA de gel de agarose}

Após terem sido submetidos a corrida em gel de agarose, o fragmento de DNA presente na banda correspondente ao perfil de migração desejado foi recortado, com o cuidado de remover-se a menor quantidade possível de gel. O bloquinho de gel foi transferido para um tubo de microcentrifuga. Utilizou-se o "Kit Prep - A Gene - DNA Purification System/Bio-Rad Laboratories", para purificação dos fragmentos de DNA desejados do bloquinho de gel de agarose.

\subsection{Desfosforilação de fragmentos de DNA}

Para se evitar a religação das extremidades dos plasmídio linearizados com enzimas de restrição, foi realizado tratamento com a enzima fosfatase alcalina ("Calf Intestinal Alkaline Phosphatase - CIAP”), que retira os radicais fosfatos de extremidades 5' do DNA. O protocolo empregado foram os enviados pelos fabricantes $\left(\right.$ Fermentas $^{\circledR}$ e Invitrogen ${ }^{\circledR}$ ).

\subsection{Ligação de fragmentos de DNAs}

De acordo com os tamanhos dos fragmentos de DNA que foram ligados, montaram-se os sistemas de ligação vetor/inserto, geralmente empregando-se a proporção de 3 a 5 vezes o número de moléculas de inserto para 1 de vetor. Empregou-se o protocolo enviado pelo fabricante da enzima DNA ligase de fago T4 (Fermentas ${ }^{\circledR}$ ).

\subsection{Transformação gênica}

\subsubsection{De células da bactéria $E$. coli}

Empregou-se o protocolo de transformação de E. coli, por eletroporação, descrito em Sambrook e Russel, 2001. As misturas de transformação foram semeadas em meio sólido LB com ampicilina $(100 \mu \mathrm{g} / \mathrm{mL})$ ou com carbenicilina $(60 \mu \mathrm{g} / \mathrm{mL})$. 


\subsubsection{De células de levedura Pichia pastoris}

Empregou-se o protocolo de transformação de $P$. pastoris, por eletroporação (Despreaux e Manning, 1993).

\subsubsection{Preparação das células}

Células de uma colônia fresca de $P$. pastoris foram inoculadas em $5 \mathrm{~mL}$ de meio YPD e o cultivo foi realizado com agitação, a $28-30^{\circ} \mathrm{C}$, durante $12-16$ horas. A seguir, $1 \mathrm{~mL}$ do pré-inóculo foi transferido para $100 \mathrm{~mL}$ de YPD, e o cultivo foi realizado nas mesmas condições até, $\mathrm{Abs}_{600}$ 1,3. As células foram, então, recuperadas por centrifugação $(1.500 \mathrm{~g}, 7$ min, $4{ }^{\circ} \mathrm{C}$ ); lavadas duas vezes com $200 \mathrm{~mL}$ de água destilada, a $4{ }^{\circ} \mathrm{C}$; uma vez com $100 \mathrm{~mL}$ de água destilada, a $4{ }^{\circ} \mathrm{C}$, uma vez com $50 \mathrm{~mL}$ de sorbitol $1 \mathrm{M}$, a $4{ }^{\circ} \mathrm{C}$; e, então, ressuspensas em $600 \mu \mathrm{L}$ de sorbitol $1 \mathrm{M}$, a $4{ }^{\circ} \mathrm{C}$.

\subsubsection{Transformação}

Num tubo "Eppendorf" a $4{ }^{\circ} \mathrm{C}$, foram misturados $40 \mu \mathrm{L}$ de células e $2-6 \mu \mathrm{L}(8-10 \mu \mathrm{g})$ de DNA linealizado do vetor de transformação. Em seguida, transferiu-se para uma cubeta a $4^{\circ} \mathrm{C}$ (BIO-Rad 0,2 cm); incubou-se em gelo por 5 minutos; colocou-se a cubeta no suporte do aparelho (Gene Pulser TM and Pulse Contoller, Bio-Rad Laboratories, Rachmond, CA USA); e aplicou-se um pulso elétrico (constante de tempo de 8 a 9 milisegundos de $1,5 \mathrm{kV}$, $25 \mu \mathrm{F}$ de capacitância e $400 \Omega$ de resistência). As células foram, então, imediatamente ressuspensas em $1 \mathrm{~mL}$ de sorbitol $1 \mathrm{M}$, e semeadas em placas contendo $\mathrm{MD}$, sem histidina, em alíquotas de 10,50200 e $570 \mu \mathrm{L}$. As placas foram incubadas em estufa a $28^{\circ} \mathrm{C}$, por 6 dias.

Os clones das leveduras que cresceram $\left(\mathrm{His}^{+}\right.$) foram, então, inoculados em placas contendo meio sólido YPD-G418, com concentração de $G 418^{\mathrm{R}}$ variando de 0,5 a $4 \mathrm{mg} / \mathrm{mL}$ ). 


\subsection{Expressão das Proteínas recombinantes VP1 e VP2 em cultivo realizado em frascos agitados}

\subsubsection{Cultivo dos clones recombinantes $P$. pastoris em frascos agitados}

Os clones da levedura $P$. pastoris GS1 $15^{\text {mutt }}$ recombinantes que cresceram em meio sólido YPD $\mathrm{G} 418^{\mathrm{R}}(4 \mathrm{mg} / \mathrm{mL}$ ) foram inoculados em $100 \mathrm{~mL}$ de meio líquido YPG contido em frascos erlenmeyers de $500 \mathrm{~mL}$ com háletas (Figura 6), adaptados exclusivamente para este trabalho. Os frascos foram incubados em "shaker" a $30^{\circ} \mathrm{C}$, até que a cultura atingisse Abs $_{600}$ 10-12 (aproximadamente 36 horas). As células foram, então, centrifugadas (2.000g por $10 \mathrm{~min}$ a $4{ }^{\circ} \mathrm{C}$ ) e ressuspensas em meio YPM. Em seguida a cada 24 horas, foram acrescentados $0,5 \%(\mathrm{v} / \mathrm{v})$ de metanol, por 4 dias consecutivos.

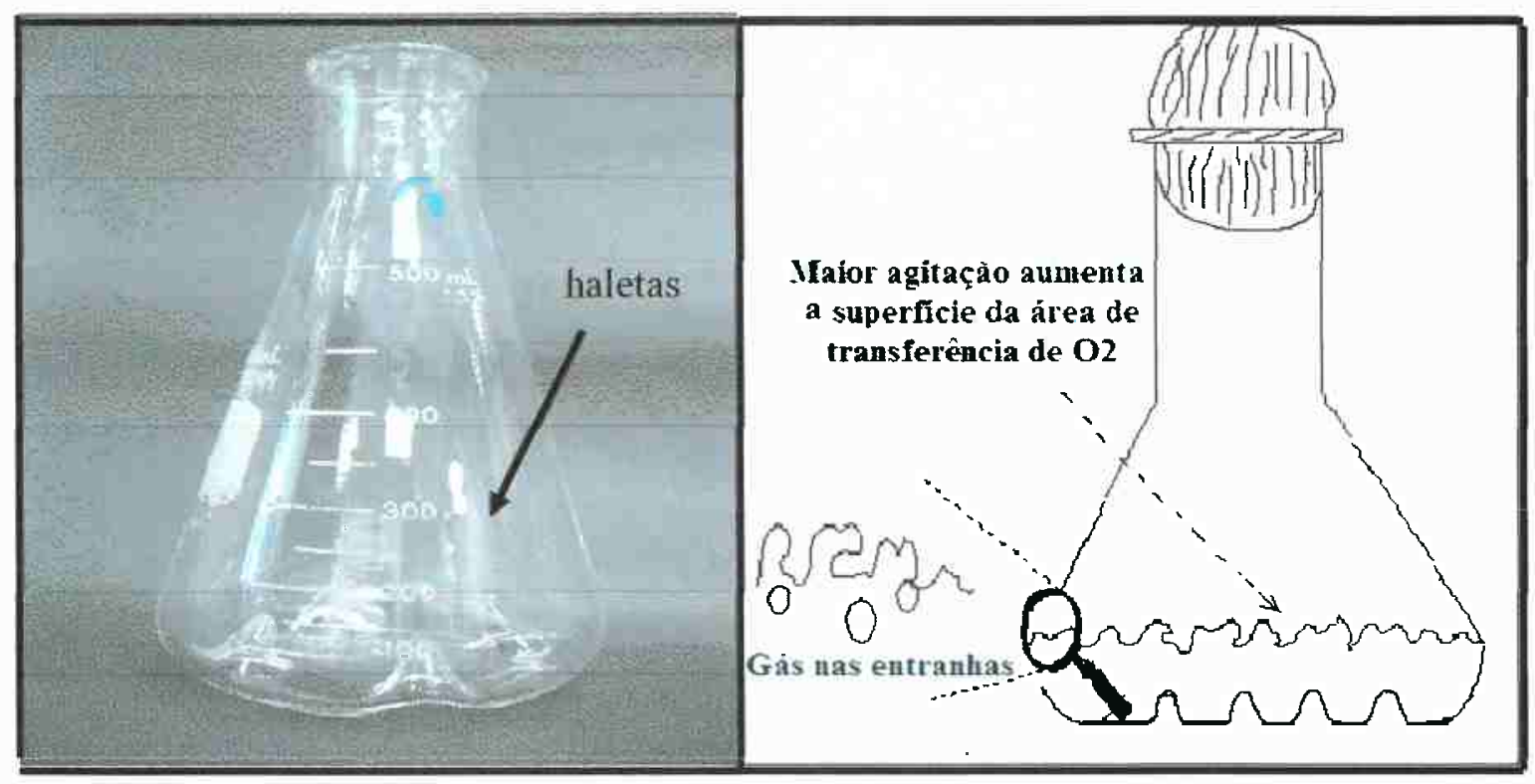

Figura 6 - Frascos erlenmeyers com haletas, adaptados para uso neste trabalho de expressão das proteínas VP1 e VP2 produzidas pelos clones recombinantes de $P$. pastoris. 
3.17.2 Obtenção do estrato bruto concentrado das proteínas VP1 e VP2 expressas em frascos agitados

Após a expressão das proteínas recombinantes VP1 e VP2 do vírus B19, em cultivo realizado em frascos agitados, o sobrenadante da cultura foi concentrado de $10^{3}$ vezes, utilizando-se um "kit concentrador Ultrafree ${ }^{\mathrm{R}}-15$ CentrifugalFilter Devise Biomax 30K (MILLIPORE)", seguiu-se o protocolo fornecido pelo fabricante. Obtiveram-se, assim, os extratos brutos concentrados.

\subsection{Análise da curva de crescimento dos clones recombinantes}

Os clones transformantes recombinantes construídos $\mathrm{GS}_{11} 15^{\mathrm{mut}} \mathrm{e}$ a linhagem $P$. pastoris GS115 foram analisadas quanto aos seus perfis das curvas de crescimento em meio de cultura líquido YPG cultivados com aeração em "shaker", a $30^{\circ} \mathrm{C}$. Após 12 horas de crescimento, foram feitas as leituras em espectrofotômetro, na $\mathrm{Ab}_{600 \mathrm{~nm}}$. As curvas de crescimento foram acompanhadas retirando-se amostras (fase exponencial) a cada 1 hora, até se chegar à fase estacionária.

\subsection{Eficiência de transformação dos plasmídios pPIC9K-VP1 e pPIC9K- VP2}

A eficiência de transformação (Ef), foi calculada empregando-se a seguinte fórmula:

$$
E f=\frac{N}{C(\mu g)}
$$

Onde: $\mathrm{N}$ é o número total de colônias obtidas na transformação; e, $\mathrm{C}$ é a concentração dos plasmídios pPIC9K-VP1, pPIC9K-VP2 e pPIC9K empregados na transformação em $(\mu \mathrm{g})$. 


\subsection{Avaliação microscópica dos transformantes}

A morfologia das células dos clones $P$. pastoris recombinantes foi avaliada, mediante análise realizada em microscópico óptico, marca Leica ${ }^{\circledR}$ DLB com câmera de captura "Hitachi KP-D581 color digital". Para tanto, durante os cultivos realizados em frascos agitados para produção da proteína recombinante, de cada uma das culturas dos clones recombinantes, foram retiradas alíquotas após o crescimento em meio líquido YPG e depois da adição de metanol, para indução da expressão das proteínas recombinantes. As células de levedura foram visualizadas em microscópio óptico.

\subsection{Expressão das proteínas recombinantes VP1 e VP2 em biorreator de} 4L

\subsubsection{Preparação do inóculo}

O inoculo foi feito a partir de estoques de suspensão de células congeladas. As células foram descongeladas à temperatura ambiente e transferidas para erlenmeyers com haletas de $250 \mathrm{~mL}$, contendo $50 \mathrm{~mL}$ de YPG. Incubadas em sob agitação de $200 \mathrm{rpm}$, a $30^{\circ} \mathrm{C}$, por $20-24$ horas. O cultivo prosseguiu até a cultura atingir $A b_{600 n m}$ entre 2 e 5 .

3.21.2 Cultivo dos clones recombinantes P. pastoris em biorreator de $4 \mathrm{~L}$ Fermentação

Para a produção das proteínas recombinantes VP1 e VP2 os clones P. pastoris recombinantes foram cultivados em um biorreator BIOSTAT ${ }^{\circledR} \mathrm{B}$, "B. Braun Biotch International", que tem um volume máximo de operação de 4L (Figura 6).

Para tanto, o pré-inóculo descrito acima foi adicionado ao biorreator (contendo o meio FM22). A agitação, temperatura, pH e a concentração de oxigênio dissolvido (DO) foram mantidos em $900 \mathrm{rpm}, 30^{\circ} \mathrm{C}, 5,0$ e $35 \%$, respectivamente.

A concentração inicial de glicerol foi de $4 \%(\mathrm{p} / \mathrm{v})$. Quando o glicerol foi completamente exaurido, a $\mathrm{Ab}_{600 \mathrm{~nm}}$ estava entre 60 e 70 . Neste ponto, foi iniciada a fase 
alimentada com glicerol $40 \%$. A taxa de alimentação do glicerol foi de $15 \mathrm{~mL} \mathrm{~L}^{-1} \mathrm{~h}^{-1}$, baseado-se no volume inicial de meio. A alimentação com glicerol foi interrompida, quando a $\mathrm{Ab}_{600 \mathrm{~nm}}$ estava entre 100 e 120 . A partir deste momento teve-se início a alimentação com metanol, a taxa de $3,5 \mathrm{~mL} \mathrm{~L}^{-1} \mathrm{~h}^{-1}$, por 12 horas, e em seguida, aumentou-se para $5 \mathrm{~mL} \mathrm{~L}^{-1} \mathrm{~h}^{-1}$. $\mathrm{O}$ incremento de metanol no biorreator foi feito em intervalos de 1 hora, até a taxa de alimentação ótima entre 11 a $12 \mathrm{~mL} \mathrm{~L}^{-1} \mathrm{~h}^{-1}$, sendo que o período de indução com metanol foi de 96 horas.

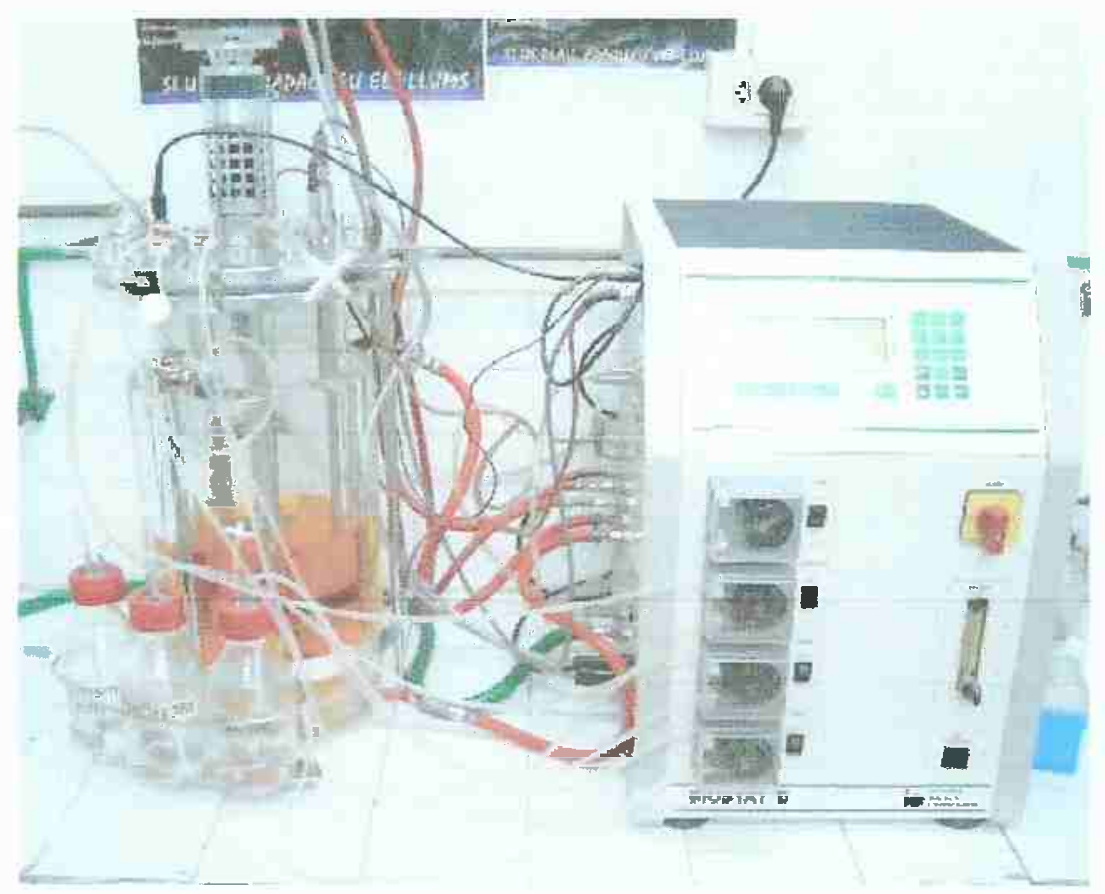

Figura 7 - Biorreator BIOSTAT ${ }^{\circledR} \mathrm{B}$, com volume máximo de $4 \mathrm{~L}$.

\subsection{Preparo de antígenos}

Após o cultivo dos clones recombinantes de $P$. pastoris em biorreator, os sobrenadantes foram obtidos mediante a centrifugação a $6.000 \mathrm{~g}$, por 10 minutos, a $4{ }^{\circ} \mathrm{C}$. Os sobrenadantes foram filtrados em membrana com diâmetro de $0,45 \mu \mathrm{m}$ (Millipore), e armazenados a $-20^{\circ} \mathrm{C}$, sendo denominados antígenos de VP1 e VP2. 
Os antígenos foram concentrados no sistema "PELLICON" (Milipore), utilizando-se o kaset $30 \mathrm{kDa}$. Esses antígenos foram dialisados contra água ultra pura, com varias trocas e após esse procedimento foram dialisados contra PBS (tampão fosfato de sódio), novamente os antígenos foram concentrados por liofilização e armazenados $\mathrm{a}-20^{\circ} \mathrm{C}$. Parte dos antígenos foi submetida à semi-purificação em cartucho SEP PAKC18, eluído 3 vezes em água ultra pura e eluído novamente em acetonitrila 100\%. Os antígenos foram concentrados por liofilização e armazenados $\mathrm{a}-20^{\circ} \mathrm{C}$.

\subsection{Dosagem de proteínas}

Os antígenos liofilizados foram ressuspensos em PBS e a quantidade de proteinas totais foi determinada pelo método de Bradford (1976), utilizando o reagente "Protein Assay (Bio Rad Laboratories)", que contém o corante azul "Coomassie", diluído 4 vezes em água destilada. A soroalbumina bovina foi utilizada como proteina padrão de referência.

\subsection{Ensaio Imunoenzimático ELISA para a deteção de anticorpos anti- B19}

Antígenos recombinantes produzidos VP1 e VP2 do vírus B19, foram analisados pelo método de ELISA. Placas de poliestireno ("Corning Costar Corporation, Cambridge, England") foram sensibilizadas com $20 \mu \mathrm{g} / \mathrm{mL}$ para VP1 e $18 \mu \mathrm{g} / \mathrm{mL}$ para VP2. Após a dessalinização, estes antígenos, foram diluídos em tampão carbonato bicarbonato $0,1 \mathrm{M}(\mathrm{pH}$ 9.6) e distribuídos nos orifícios de uma placa ELISA, $25 \mu \mathrm{g} / \mathrm{mL}$ para VP1 e $10 \mu \mathrm{g} / \mathrm{mL}$ para VP2 com ( $50 \mu \mathrm{L} /$ orificio), e incubadas por 16 horas, a $4^{\circ} \mathrm{C}$. As placas foram lavadas 3 vezes com PBS e os sítios livres foram bloqueados pela adição de tampão PBS contendo BSA 5\% (Sigma) $(50 \mu \mathrm{L} /$ orifício), por 4 horas, à temperatura ambiente. Após 3 lavagens com PBS, foram adicionados, a cada orificio, $50 \mu \mathrm{L}$ dos soros testes em diluições de base 2 a partir de $1 / 25 \mathrm{em}$ PBS/BSA $1 \%$. As placas foram incubadas por 1 hora a temperatura ambiente. Decorrido este período, as placas foram lavadas por 3 vezes com PBS/Tween 20 a $0,05 \%$ e incubadas, por 1 hora, a temperatura ambiente, com antissoro conjugado com fosfatase 
alcalina (antissoro de cabra conjugado com fosfatase alcalina antiimunoglobulina $\mathrm{G}$ de humana - Gibco BRL, Gaithersburg, MO, USA) diluído 1/1000, em PBS/Tween 0,05\%/BSA 1\%. Após 3 lavagens com PBS/Tween 0,05\%/BSA, a reação foi revelada pela adição de 1 $\mathrm{mg} / \mathrm{mL}$ de p-nitrafenilfosfato (pNPP - Sigma) dissolvido em Tris 1 M (pH 9.8) (1 parte) e $\mathrm{NaCI} 1,5 \mathrm{M}$ (9 partes). Após 20 minutos, a reação foi interrompida, , pela adição de $\mathrm{NaOH} 3$ M. Os resultados foram avaliados por leitura espectrofotométrica a $405 \mathrm{~nm}$, em leitor de placas de ELISA (Multiskan MS - Labsystems).

Foram utilizados, como controle positivo nos ensaios do ELISA, Dot-Blot e Western Blot, amostras sorológicas de pacientes com diagnóstico positiva para o vírus B19, clinicamente fundamentado pelas técnicas de ELISA e PCR, com alto título de carga viral. Como controle negativo, foi utilizado soro normal negativo para B19. Todas as amostras de soros humanos foram provenientes do Laboratório de Virologia Clínica Molecular do Instituo de Ciências Biomédicas da Universidade de São Paulo.

\subsection{Análise Eletroforética das proteínas recombinantes VP1 e VP2 em géis de poliacrilamida}

\subsubsection{SDS-PAGE}

As proteínas recombinantes VP1 e VP2 foram submetidas à eletroforese vertical em gel de poliacrilamida com dodecil sulfato de sódio (SDS-PAGE)(Laemmli, 1970). Para a separação das proteínas foi utilizado gel de concentração contínua com $10 \%$ de acrilamida) $(4,5 \mathrm{~cm} \times 10 \mathrm{~cm})$. Para o empilhamento das amostras, foi utilizado gel na concentração de $5 \%$ de acrilamida $(3 \mathrm{~cm} \times 10 \mathrm{~cm})$, com espessura de $1,5 \mathrm{~mm}$. Os géis foram preparados utilizando-se as seguintes soluções: acrilamida $30 \%$ e bis-acrilamida $0,98 \%$; Tris-HCI 1,0 M ( $\mathrm{pH}$ 8.8), Tris - $\mathrm{HCl}$ 0,5 M (pH 6.8) e água ultra pura, TEMED (BIO-RAD) e persulfato de amônio (BIO-RAD). Os antígenos VP1 $(3,5 \mu \mathrm{g})$ e VP2 $(3,0 \mu \mathrm{g})$ foram solubilizadas em tampão de amostra para SDS-PAGE, constituído de: Tris-HCl 0,0625 M (pH 6.8), SDS 2\%; glicerol 20\%, azul de bromofenol ("Pharmacia Fine Chemicals, Uppsala, Sweden"). Estas suspensões foram aquecidas a $100^{\circ} \mathrm{C}$, em água fervente, durante 4 minutos. As misturas de proteínas de calibração de peso molecular (BIO-RAD), foram constituídas por: PM miosina (200 kDa), $\beta$-galactosidade $(116,25 \mathrm{kDa})$, fosforilase $\mathrm{B}(97,0 \mathrm{kDa})$, soroalbumina bovina 
$(66,2 \mathrm{kDa})$, ovoalbumina (45 kDa), anidrase carbônica (31,0 kDa); inibidor de tripsina $(21,5$ $\mathrm{kDa})$ e lisosima $(14,4 \mathrm{kDa})$.

\subsubsection{Corridas Eletroforéticas}

O tampão utilizado nas corridas eletroforéticas dos géis de poliacrilamida foi Tris 0,025 M, glicina 0,192 M, SDS 0,5 M, ( $\mathrm{pH} \mathrm{8.3).} \mathrm{A} \mathrm{corrente} \mathrm{contínua} \mathrm{utilizada} \mathrm{na} \mathrm{eletroforese}$ foi $100 \mathrm{~V}$ por um período de 90 minutos, para géis de concentração contínua. A fonte utilizada foi Bio-Rad Power PAC 300.

\subsubsection{Coloração com "Coomassie Blue"}

Para revelação das bandas protéicas dos géis de poliacrilamida, os géis foram incubados a temperatura ambiente por 16 horas em uma solução de "Coomassie-blue" R-250 $(0,25 \%$ em solução de metanol, água e ácido acético $-5: 5: 1)$. A remoção do excesso de corante foi obtida incubando-se em solução de etanol, água e ácido acético $(4,35: 4,65: 1)$ até o aparecimento nítido das bandas de proteínas. Os géis foram mantidos em ácido acético $7,5 \%$.

\subsection{Determinação do peso molecular das proteínas recombinantes}

Para a determinação do peso molecular das proteínas recombinantes construiu-se um gráfico do logarítimo do peso molecular das proteínas empregadas para calibração (padrões) versus as suas mobilidades $(\mathrm{em} \mathrm{cm}$ ) no gel que havia submetido a corrida eletroforética e corado, para revelação das bandas.

A equação da reta obtida com as proteínas padrão é utilizada para a determinação da massa molecular relativa de cada banda de proteína recombinante (Figura 8 e Tabela 5). 


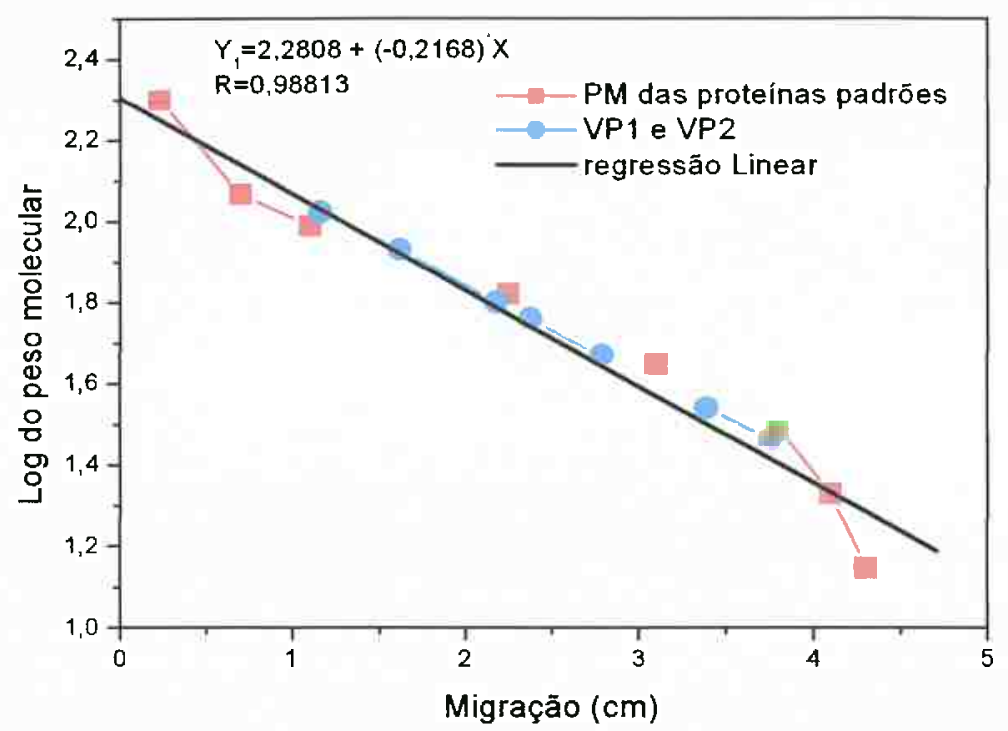

Figura 8 - Peso molecular relativo de cada uma das proteínas caracterizadas no SDS-PAGE. 0 tracejado em vermelho indica o logarítimo do peso molecular das proteínas padrões: miosina (200 kDa), $\beta$-galactosidade $(116,25 \mathrm{kDa})$, fosforilase $\mathrm{B}(97,0 \mathrm{kDa})$, soro albumina bovina $(66,2 \mathrm{kDa})$, ovoalbumina $(45 \mathrm{kDa})$, anidrase carbônica $(31,0 \mathrm{kDa})$; inibidor de tripsina $(21,5 \mathrm{kDa})$ e lisosima $(14,4 \mathrm{kDa})$, utilizadas como padrão, em relação à medida de sua migração em SDS-PAGE $10 \%$. $O$ tracejado em verde representa o logarítimo do peso molecular de cada proteína, em relação à medida de sua migração no SDS-PAGE $12 \%$. A partir do gráfico visualizado obteve-se a equação da reta $\mathrm{Y}=2,2808+\left(-0,2168^{*} \mathrm{X}\right)$.

Tabela 5 - Parâmetros calculados para a determinação do peso molecular relativo das proteínas recombinantes VP1 e VP2, resultantes da caracterização em "SDS-PAGE". Na coluna da direita, são apresentados os valores dos pesos moleculares de cada uma das bandas proteínas visualizadas no gel (bandas), após a corrida eletroforética.

\begin{tabular}{|c|c|c|c|c|}
\hline $\begin{array}{c}\text { Padrão de Peso } \\
\text { Molecular (PM) kDa }\end{array}$ & Log PM & Bandas & $\begin{array}{c}\text { Migração das bandas } \\
(\mathrm{cm})\end{array}$ & $\begin{array}{c}\text { Peso molecular }(\mathrm{kDa}) \\
\mathrm{Y}=2,2808+\left(-0,2168^{*} \mathrm{X}\right)\end{array}$ \\
\hline 200,0 & 2,3 & - & 0,23 & - \\
\hline 116,2 & 2,06 & -- & 0,7 & --- \\
\hline 97,4 & 1,98 & -- & 1,1 & -- \\
\hline 66,2 & 1,82 & -- & 2,25 & --- \\
\hline 45,0 & 1,65 & -- & 3,1 & --- \\
\hline 31,0 & 1,49 & -- & 3,8 & --. \\
\hline 21,5 & 1,33 & -- & 4,1 & --- \\
\hline 14,4 & 1,15 & -- & 4,3 & $-\cdots$ \\
\hline-- & -- & 1 & 0,22 & 170 \\
\hline-- & -- & 2 & 1,1 & 105 \\
\hline- & - & 3 & 1,6 & 85,4 (VP1) \\
\hline-- & -- & 4 & 2,1 & 63,5 \\
\hline-- & -- & 5 & 2,3 & $57,8 \quad(\mathrm{VP} 2)$ \\
\hline-- & - & 6 & 2,7 & 47 \\
\hline -- & -- & 7 & 3,3 & 38 \\
\hline
\end{tabular}

Onde : $\mathrm{Y}=$ Log do P.M.da proteina

$\mathrm{X}=$ migração de cada proteína no gel $(\mathrm{cm})$ 


\subsection{Títulação de IgG}

Para a titulação da imunoglobolina G (IgG) presentes no soro de pacientes, foi realizada uma curva de regressão linear do $\log ^{2}$ da D.O. da leitura obtida pelo ELISA em função do $\log ^{2}$ da diluição. Definimos como título a recíproca da diluição correspondente a uma D.O de 0,1 .

\subsection{8 "Dot-Blot"}

$\mathrm{Na}$ membrana de nitrocelulose, foram adicionado $2,0 \mu \mathrm{g}$ de antígenos recombinantes VP1 e $2,5 \mu \mathrm{g}$ do antígeno recombinante VP2. Após a incubação da membrana a temperatura ambiente por 16 horas, a membrana foi bloqueada com uma solução de TBS/BSA $5 \%$, e submetida a incubação a temperatura ambiente, com agitação, por 20 minutos. Após lavagem por 3 vezes com TBS, foi adicionado o soro humano de pessoas comprovadamente positivas para o vírus B19, e soro de pessoas não infectadas com B19 (controle negativo). Incubados por 1 hora, a temperatura ambiente. Após este período, as membranas foram lavadas por 3 vezes com TBS por 3 minutos, e incubadas por 1 hora com antissoros conjugados com fosfatase (soro de cabra conjugado com fosfatase anti-lgG de humano - Sigma (San Francisco, CA, USA). Após 3 lavagens com TBS por 3 minutos, a reação foi revelada pela adição de NBT $33 \mu \mathrm{L}$ e BCIP 16,5 $\mu \mathrm{L}$ (PIERCE -(Rockford ILLinois U.S.A.) em $5 \mathrm{~mL}$ de tampão AP revelador. Após coloração, a reação foi interrompida com água destilada.

\subsection{9 "Western Blot"}

As proteínas provenientes do sobrenadantes do cultivo dos clones recombinantes $P$. pastoris, após terem sido submetidas a migração em géis de SDS-PAGE foram transferidas eletroforeticamente para membranas de nitrocelulose ("BIO-RAD"), conforme descrito (Towbin e Gordon, 1979).

A transferência foi realizada por 16 horas, a $4^{\circ} \mathrm{C}$, sob amperagem constante de 180 
mA, em tampão Tris 0,025 ; glicina 0,192 M, metanol 20\%, (pH 8.3). Após a tranferência, as membranas de nitrocelulose foram incubadas, por 4 horas, em uma solução bloqueadora de TBS/BSA 5\%, a temperatura ambiente, com agitação. Após lavagem, com TBS por 3 vezes, estas foram incubadas com os soros humanos de pessoas: comprovadamente positivos para o vírus B19 e soro de pessoas não infectadas pelo virus B19 (controle negativo). Incubou-se por 1 hora a temperatura ambiente. Após este periodo, as membranas foram lavadas por 3 vezes com TBS, por 3 minutos, e incubadas por 1 hora com antissoros conjugados com fosfatase (soro de cabra conjugado com fosfatase anti-lgG de humano - Sigma (San Francisco, CA, USA). Após 3 lavagens com TBS por 3 minutos, a reação foi revelada pela adição de NBT 33 $\mu \mathrm{L}$ e BCIP 16,5 $\mu \mathrm{L}$ (PIERCE -(Rockford ILLinois U.S.A.) em $5 \mathrm{~mL}$ de tampão AP revelador. Após coloração, a reação foi interrompida com água destilada. 


\section{RESULTADOS}

\subsection{Clonagem dos genes codificadores das proteínas VP1 e VP2 do vírus B19 vetor intermediário pGEM-TEasy.}

Os fragmentos de DNA, correspondentes aos genes estruturais que codificam as proteínas VP1 (2,343 pb) e VP2 (1,664 pb) do parvovirus humano B19 (Durigon et al., 1993), foram obtidos por amplificação por PCR utilizando, como DNA molde, soros de amostras clínicas de pacientes com diagnóstico clínico e laboratorial de infecção pelo vírus B19, provenientes do Laboratório de Virologia Clínica Molecular do Instituto de Ciências Biomédicas da Universidade de São Paulo (Erdman et al., 1996).

Essas amostras foram obtidas de acordo com as exigências de bioéticas pertinentes ao estudo. O diagnóstico laboratorial havia sido baseado na detecção de anticorpos IgM e IgG para o parvovírus B19 (método de ELISA) e método de captura e detecção direta do DNA viral (técnica da PCR -Reação em Cadeia pela Polimerase) (Vicari et al., 2002).

4.1.1 Obtenção dos fragmentos de DNA codificadores das proteínas VP1 e VP2 do vírus B19

Neste trabalho, foram utilizados os oligonucleotídeos iniciadores Pv1, Pv2 e Pv (Tabela 4, Materiais e Métodos), especialmente desenhados para garantir o sucesso das etapas seguintes de clonagem (Figuras 9 e 10).

Os amplicons resultantes de cada PCR foram submetidos a uma corrida eletroforética em gel de agarose $0,7 \%$ (Figura 11), e os fragmentos de DNA correspondentes a cada um dos geñes foram eluídos deste gel (Figura 12). 

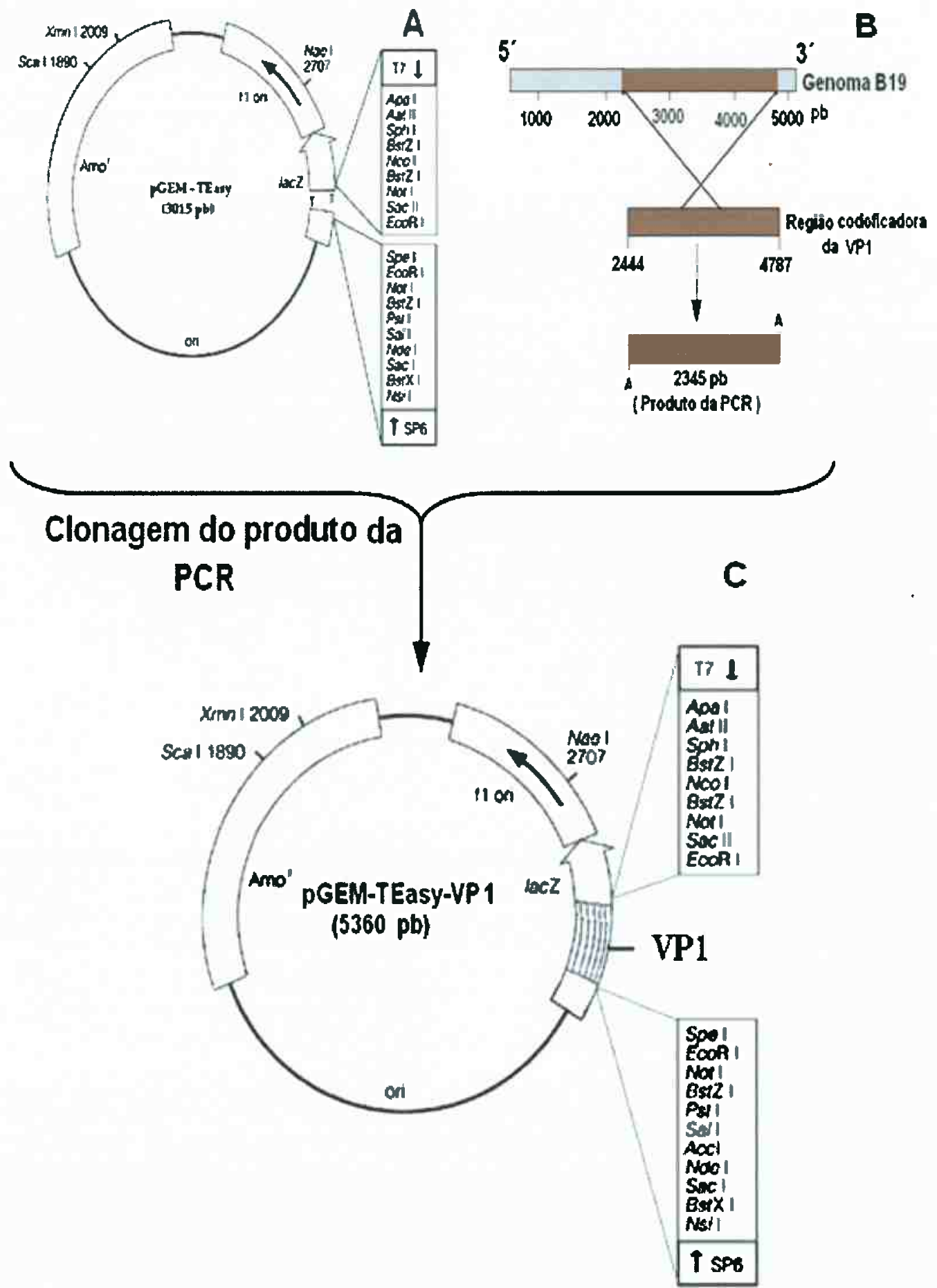

Figura 9 - Esquema de construção do plasmídio pGEM-TEasy-VP1, a partir do DNA total do vírus B19 (Durigon et al., 1993; Erdman, 1996). 

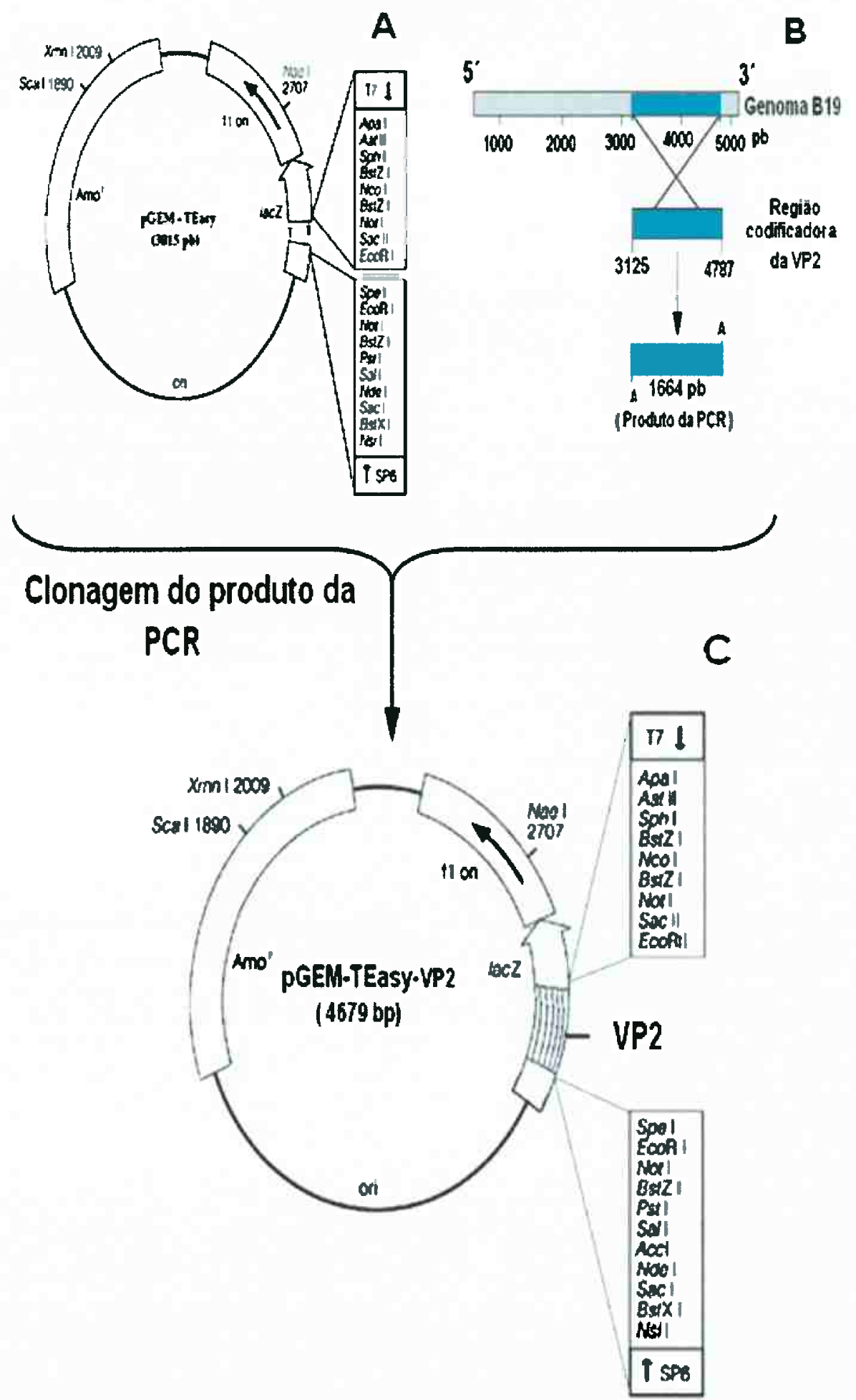

Figura 10 - Esquema de construção do plasmídio pGEM-TEasy-VP2, a partir do DNA total do vírus B19 (Durigon et al., 1993; Erdman, 1996). 


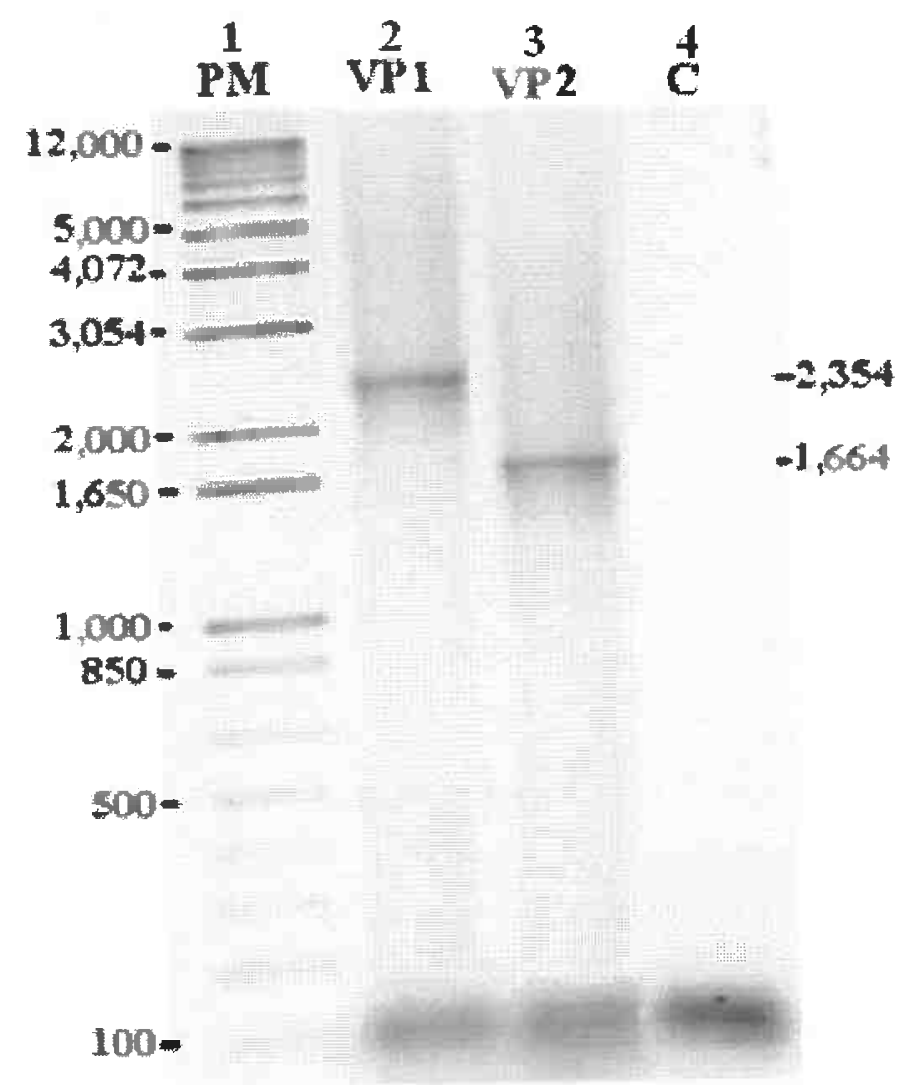

Figura 11 - Fragmentos de DNA VP1 e VP2 amplificado por PCR submetidos a corrida eletroforética em gel de agarose 0,7\%: 1 - PM - marcador DNA Ladder $1 \mathrm{~kb}$ Plus, Invitrogen ${ }^{\circledR}(0,25$ $\mu \mathrm{g}) ; 2$ e 3 - amplicons VP1 e VP2 obtidos na reação da PCR empregando-se como molde DNA viral de vírus B19; 4- C, controle negativo. 


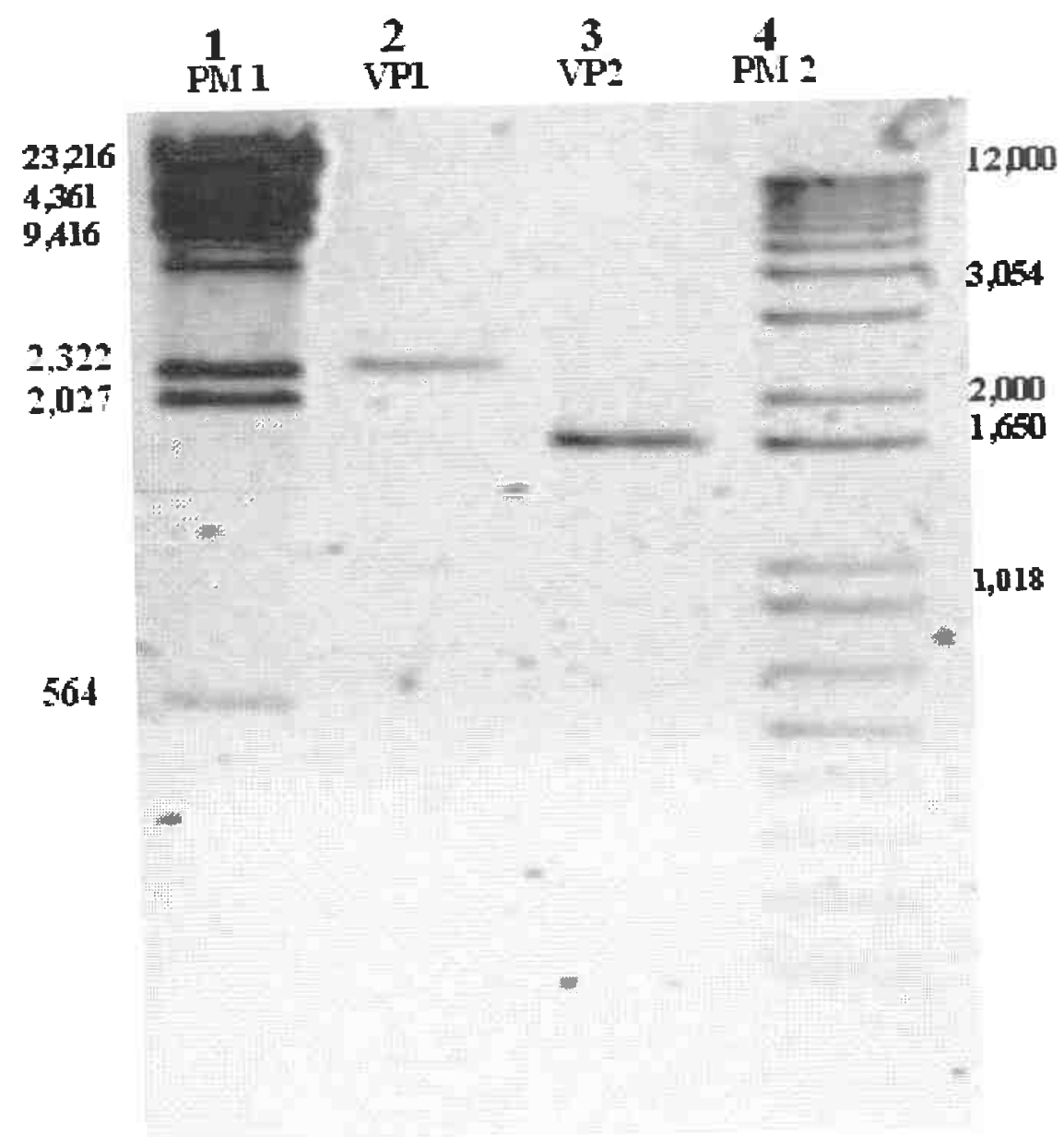

Figura 12 - Fragmentos de DNA VP1 e VP2 eluídos do gel de agarose 0,7\%: 1 - PM1- marcador de tamanho molecular $\lambda$ DNA/HindIII, Invitrogen $(0,5 \mu \mathrm{g}) ; 2$ - fragmento de DNA VP1; 3 fragmento de DNA VP2; 4 - PM2 - marcador DNA Ladder $1 \mathrm{~kb}$ Plus, Invitrogen $(0.25$ $\mu \mathrm{g})$.

\subsubsection{Clonagem dos fragmentos de DNAs VP1 e VP2 em pGEM-TEasy}

Fragmentos de DNA codificadores das proteínas VP1 e VP2 foram clonados no vetor pGEM-TEasy. Para tanto, os fragmentos de DNA foram empregado em misturas de ligação com pGEM-TEasy (Figura 9 e 10) que foram empregadas na transformação genética de $E$. coli $\mathrm{DH} 5 \alpha$. Foram obtidas mais de 100 colônias de bactérias E. coli $\mathrm{Amp}^{\mathrm{R}}$, de cada uma das misturas de ligação. Plasmídios isolados de 50 clones selecionados ao acaso foram analisados, empregado-se digestão com as enzimas de restrição NotI e EcoRI e análise em gel de agarose submetido à eletroforese: 28 clones apresentaram resultado positivo para o inserto VP1 (fragmentos de DNA: de 3,015 pb (vetor pGEM-TEasy) e 2,345 pb (inserto VP1)); e 25 
clones apresentaram resultados positivos para o inserto VP2 (fragmento de DNA: 3,015 pb (vetor pGEM-TEasy) e 1,665 pb (inserto VP2)), (Figura $13 \mathrm{~A}$ e B) (Tabela 5). Os novos plasmídios recombinantes, foram denominados pGEM-TEasy-VP1 e pGEM-TEasy-VP2.

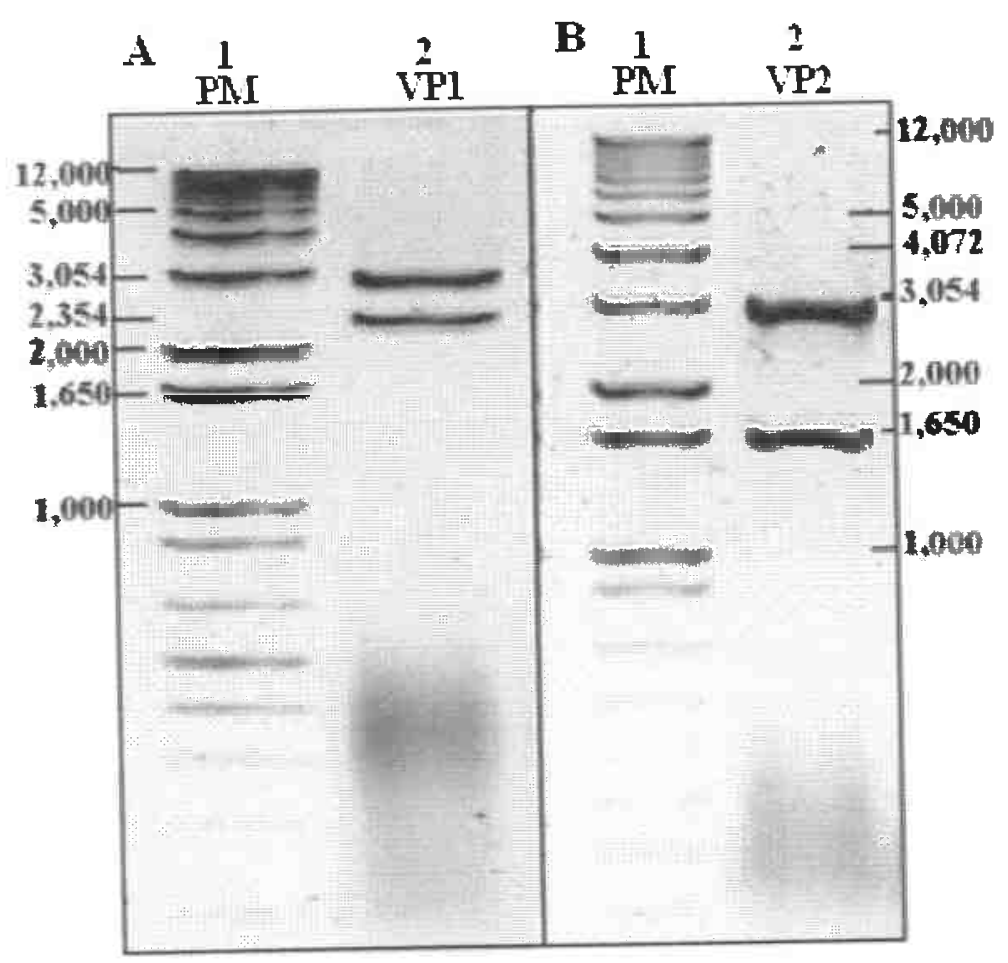

Figura 13 - Gel de agarose 0,7\% submetido a eletroforese : A, pGEM-TEasy-VP1: 1 - PM, marcador DNA Ladder, Invitrogen $1 \mathrm{~kb}$ Plus $(0,25 \mu \mathrm{g}) ; 2$ - vetor digerido com EcoRI $e$ NotI. B; 2 - pGEM-TEasy-VP2: 1 - PM, marcador DNA Ladder, Invitrogen $1 \mathrm{~kb}$ Plus $(0,25 \mu \mathrm{g}): 2$ - vetor digerido com EcoRI e NotI;

\subsection{Clonagem dos fragmentos de DNA codificadores de VP1 e VP2 no vetor de expressão e excreção de Pichia pastoris pPIC9K}

Visando obter-se a expressão e excreção das proteínas VP1 e VP2 em P. pastoris, escolheu-se, como vetor de clonagem o plasmídio pPIC9K $\left(H I S 4, \mathrm{G} 418^{\mathrm{R}}\right)$. Este vetor permite a seleção dos transformantes de levedura por complementação gênica e por resistência a geneticina $\mathrm{G} 418$. 
As estratégicas adotadas nas construções dos vetores estão demonstradas nas Figuras 14 e 15.

4.2.1 Extração Eluição dos fragmentos VP1 e VP2 dos plasmídios pGEMTEasy-VP1 e pGEM-TEasy-VP2

Para a obtenção dos insertos que seriam empregados na construção do vetor de transformação $P$. pastoris, os fragmentos de DNA contendo os genes VP1 e VP2 foram extraídos dos plasmídios recombinantes pGEM-TEasy-VP1 e pGEM-TEasy-VP2. Para tanto, estes plasmidios foram digeridos com as enzimas de restrição NotI e EcoRI, os fragmentos de DNA VP1 e VP2 foram eluídos do gel de agarose.

4.2.2 Clonagem dos fragmentos de DNA codificadores de VP1 e VP2 em pPIC9K

Para construção dos vetores de transformação genética em $P$. pastoris, foram elaboradas as misturas de ligação do vetor PPIC9K, previamente digerido com as enzimas de restrição EcoRI e NotI, com os insertos VP1 e VP2 obtidos conforme descrito acima (proporção $1 / 5$ das moléculas).

Foram obtidas mais de 100 colônias de transformantes $E$. coli DH5a Amp ${ }^{\mathrm{R}}$, com cada uma das misturas de ligação. Dentre os plasmidios isolados destas colônias que foram analisados, 10 apresentaram resultado positivo para o inserto VP1, e 14 para inserto VP2 (Tabela 6). Os perfis de migração em gel de agarose dos plasmídios recombinantes clivados com as enzimas de restrição EcoRI e NotI estão apresentados na Figura 16.

Os novos plasmídios recombinantes construídos, foram denominados de pPIC9K-VP1 e pPIC9K-VP2 (Figuras 14 e 15). 


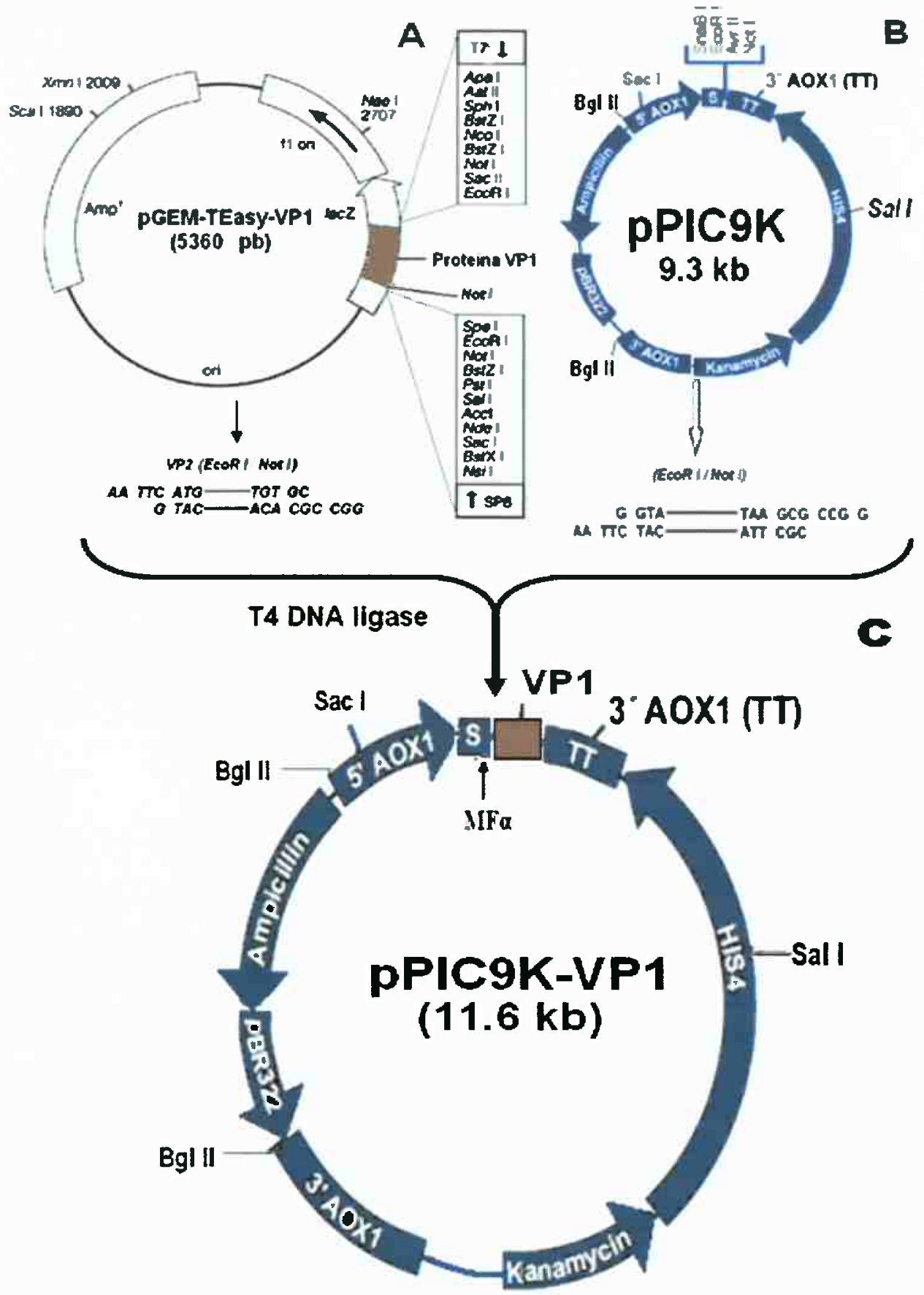

Figura 14 - Esquema de construção do plasmídio pPIC9K-VP1. 

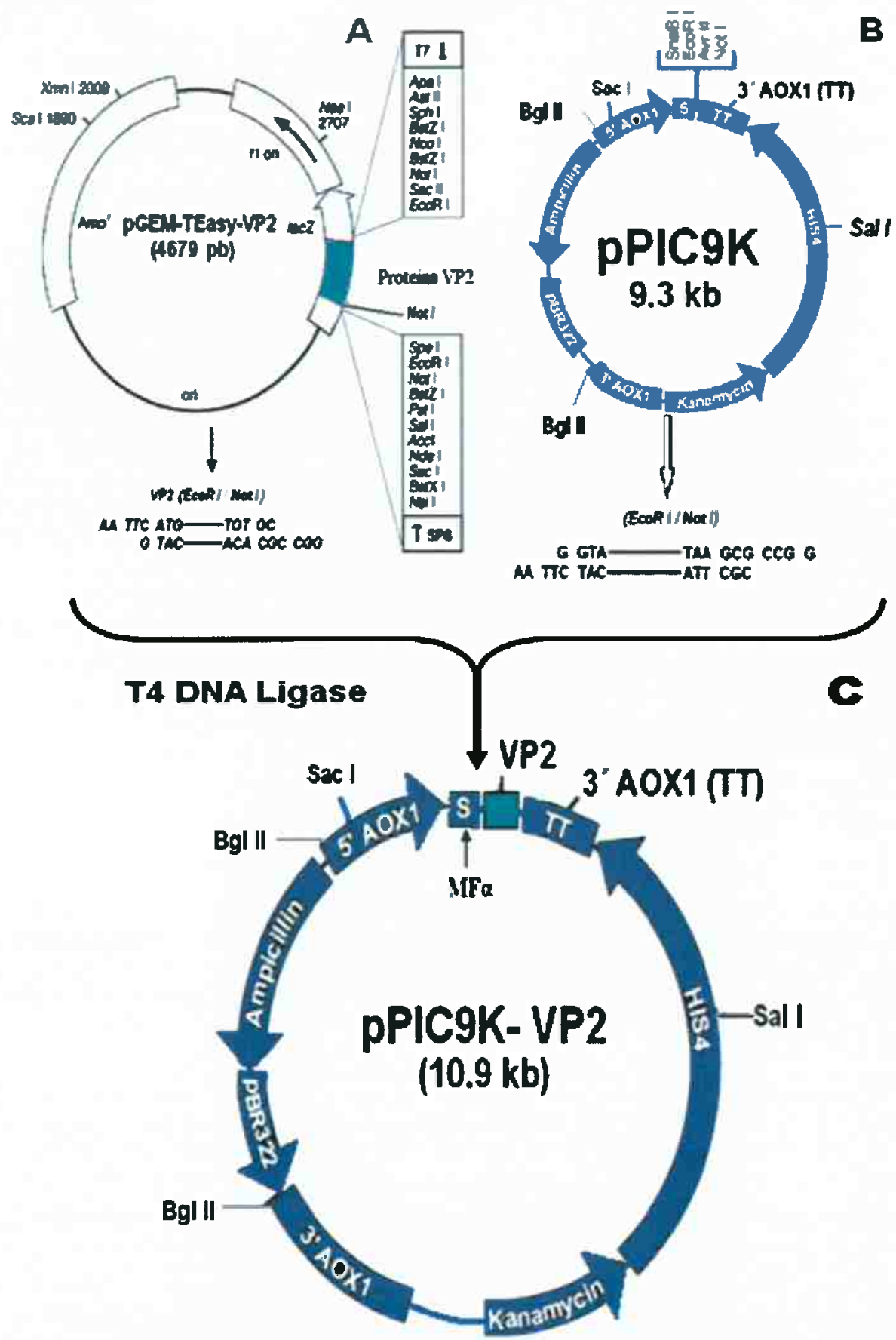

Figura 15 - Esquema de construção do plasmídio pPIC9K-VP2. 


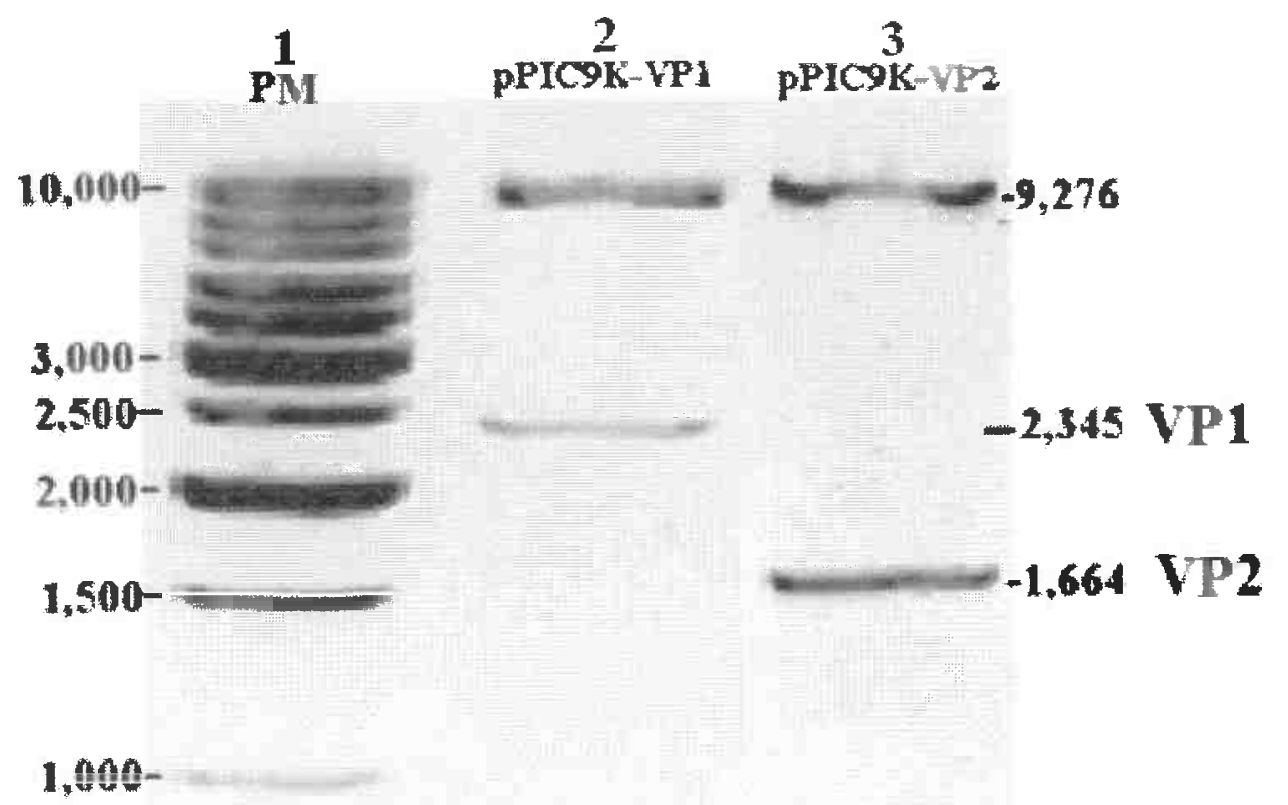

$750-$

500-

Figura 16 - Gel de agarose 0,7\% submetido a eletroforese : 1 - PM, marcador molecular DNA Ladder $1 \mathrm{~kb}$, Fermentas $(0,25 \mu \mathrm{g})$; 2- pPIC9K-VP1; 3- pPIC9K-VP2 digeridos com as enzimas de restrição EcoRI e NotI.

Tabela 6 - Número de colônias de transformantes E. coli $\mathrm{DH} 5 \alpha \mathrm{Amp}^{\mathrm{R}}$ obtidas com os plasmídios construídos neste trabalho.

\begin{tabular}{lccc}
\hline \multicolumn{1}{c}{ Plasmídio } & \multicolumn{2}{c}{$\mathrm{N}^{\circ}$ de Colonias Amp } & com inserto \\
recombinante & Obtidas & Analisadas & $(\%)$ \\
\hline pGEM-TEasy-VP1 & $>100$ & 50 & 28 \\
pGEM-TEasy-VP2 & $>100$ & 50 & 25 \\
pPIC9K-VP1 & $>100$ & 90 & 10 \\
pPIC9K-VP2 & $>100$ & 100 & 14 \\
\hline
\end{tabular}




\subsection{Sequenciamento genes VP1 e VP2 clonados nos plasmídios pPIC9K-VP1 e pPIC9K-VP2}

Foram realizados os sequenciamentos dos fragmentos de DNA codificadores das proteínas VP1 e VP2 do vírus B19, que haviam sido inseridos no final da transformação de $P$. pastoris $\mathrm{pPIC} 9 \mathrm{k}-\mathrm{VP} 1$ e pPIC9k-VP2.

Foram utilizados nestes sequenciamentos os "primers" reversos (Pr (pPIC9k-VP1) e P19r (pPIC9k-VP2) (Tabela 4, Materiais e Métodos), que se anelavam internamente no início de cada uma das ORFs de leitura dos fragmentos VP1 e VP2; e o "primer Forward" Ps (o mesmo para ambos, que anela dentro do MFa) (Figura 5 e Tabela 4), desenhados, exclusivamente, para amplificar estas regiões.

A análise do sequenciamento mostrou que as seqüências dos genes que codificam as proteínas VP1 e VP2 do B19 apresentavam quadro correto de leitura, incluindo a reconstituição de sítio do restrição Eco $\mathrm{RI}$, que havia sido inserido como cauda nos "primers" forward Pv1 e Pv2 (Anexo 1 e 2).

Os cromatogramas dos sequenciamentos parciais e o quadro demonstrativo da seqüência de aminoácidos demonstrando a inserção destes genes em fase correta de leitura nestes plasmídios estão demonstrados nas Figuras 17 e 18. Nestas figuras estão destacadas as regiões de início dos genes codificadores das proteínas VP1 e VP2, bem como a posição dos "primers" Pv1 e Pv2. 


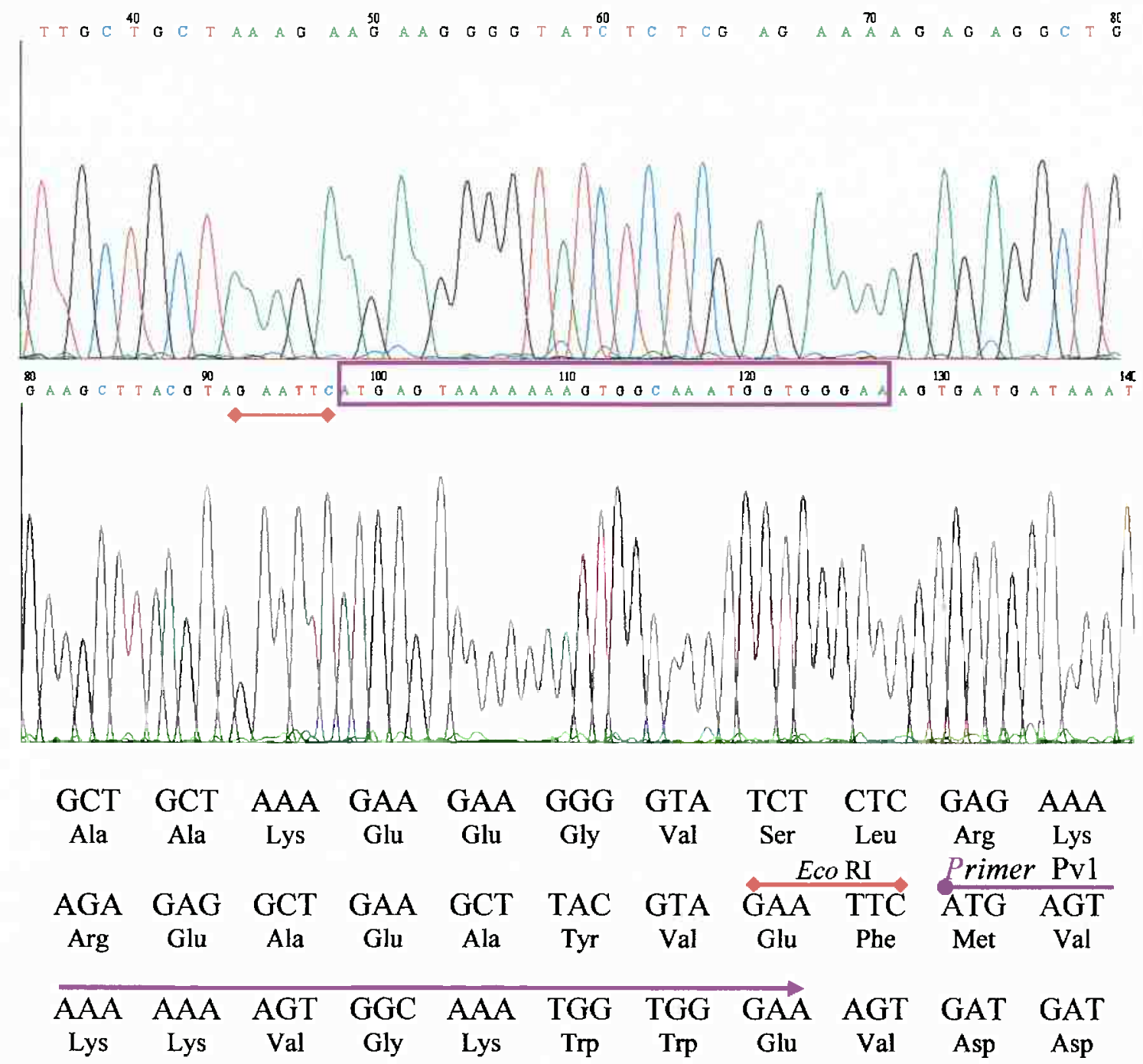

Figura 17 - Esferograma do sequenciamento do gene VP1 clonado no plasmídio pPIC9K-VP1, com a região de inserção do "primer" Pvl e o sítio de restrição Eco RI, juntamente com o quadro da fase correta de leitura. 


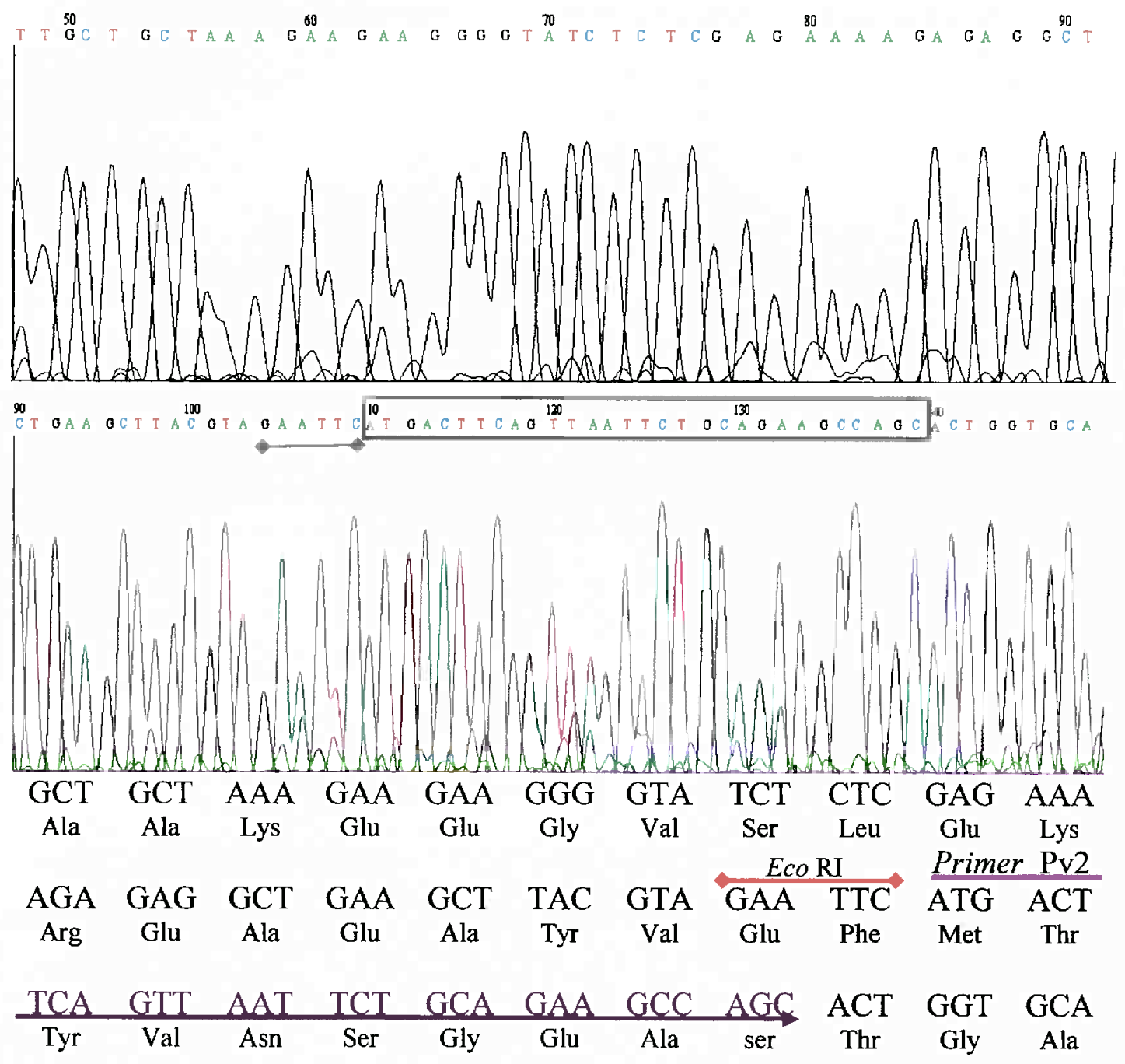

Figura 18 - Esferograma do sequenciamento do gene VP2 clonado no plasmídio pPIC9K-VP2, com a região de inserção do "primer" Pv2 e o sito de inserção Eco RI, juntamente com o quadro correto da fase de leitura. 


\subsection{Análise das proteínas recombinantes VP1 e VP2 que seriam produzidas pelos clones $P$. pastoris recombinantes}

As seqüências codificadores dos genes VP1 e VP2 clonados em pPIC9K-VP1 e pPIC9K-VP2, foram analisadas pelo programa "SeqMan ${ }^{\mathrm{TM}} 4,05$ DNA Star," sendo gerado "contigs" destes genes. Este procedimento resultou em diversas seqüências consensos para cada um dos fragmentos de DNA, de acordo com os "primers" que foram utilizados. Quando estas seqüências foram montadas, resultaram em dois consensos (VP1 e VP2), que foram alinhados, utilizando o programa "MegAlign ${ }^{\mathrm{TM}}$ expert sequence analysis software", com as seqüências padrão de VP1 e VP2 do vírus B19, que havia sido utilizada como parâmetro para desenho dos "primers" (Shade et al. 1986, GenBanK com o número de acesso M13178). As sequiências completas de VP1 e VP2 clonados em pPIC9K-VP1 e pPIC9K-VP2 encontram-se apresentados nos Anexos A e B.

A partir das seqüências de DNA codificadoras de VP1 e VP2 clonados em pPIC9KVP1 e pPIC9K-VP2, neste trabalho, foi feita a tradução eletrônica. $O$ alinhamento das seqüências de aminoácidos que codificam as proteínas recombinantes VP1 e VP2 com a sequiência equivalente do GenBank, levou a identificação de mudanças que estão apresentadas na Tabela 7. Os resultados destes alinhamentos estão esquematizados nas Figuras (19 e 20), os aminoácidos em que foram identificados mudanças estão delimitados em vermelho.

Tabela 7 - Posição dos aminoácidos no sequenciamento de VPI e VP2, que apresentaram mudanças no alinhamento com a seqüência padrão do vírus B19 GenBank (Shade et al., 1986).

\begin{tabular}{ccc}
\hline Proteína & Aminoácido & Posição \\
\hline VP1 & Serina (S) / Prolina P & 247 \\
VP1 & Serina (S) / Treonina (T) & 456 \\
VP2 & Serina (S) / Prolina (P) & 20 \\
VP2 & Serina (S) / Treonina (T) & 229 \\
VP2 & Serina (S) / Glicina (G) & 428 \\
\hline
\end{tabular}




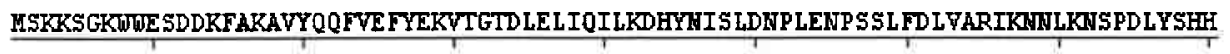

$\begin{array}{lllllll}10 & 20 & 30 & 40 & 50 & 60 & 70\end{array}$

Seq. GenBenk VP1 MSKKSGKWWESDDKFAKAVYQQFVEFYEKVTGTDLELIOILKDHYNISLDNPLENPSSLFDLVARIKNNLKWSPDLYSHH 238 Pb

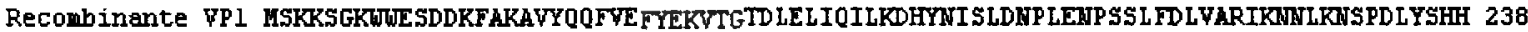

FQSHGQLSDHPHALSSSSSHAEPRGENAYLSSEDLHKPGOVSYOLPGTNYYGPGNELQAGP PQSAYDSAKRIHDFRYSQL

$\begin{array}{llllllll}90 & 100 & 110 & 120 & 130 & 140 & 150 & 160\end{array}$

Seq. GenBank VPl FQSHGQLSDHPHALSSSSSHAEPRGEHAVLSSEDLHKPGQVSVOLPGTWYGGPGNELQGPPQSAVDSAARIHDFRYSOL 478

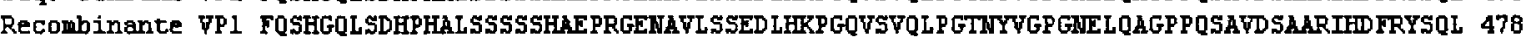

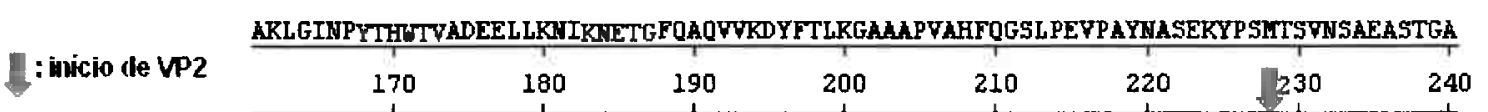

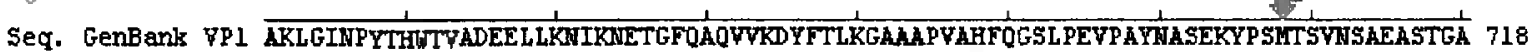
Recombinante YP 1 AKLGINPYTHUIVADEELLKNIKNETGFOAQYYDYFTLKGAAAPVAHFOGSLPEYPAYNASEKYPSHTSYNSAEASTGA 718

GGGGSW SWKSHWSEGKTFSANSYTCTFSROFLIPYDPEHHYKV FSPAASSCHHASGKEAKVCTISPIMGYSTPURYLDFN

\begin{tabular}{l|lllllll}
\hline & 1 & 1 & 1 & 1 & & 310 & 320
\end{tabular}

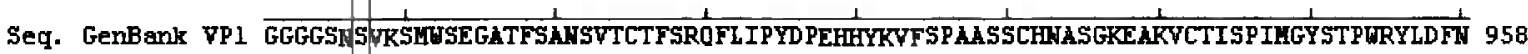
Recombinante VP1 GGGGSNPYKSWUSEGATFSANSYTCTFSROFLIPYDPEHHYKYFSPAASSCHNASGKEAKYCTISP IMGYSTPURYLDFH 958

ALNLFFSPLEFOHLIENYGSIAPDALTVTISE IAVKDVTDKTGGGVDVIDSTTGRLCHL VDHEYKYPYVLGQGODTLAPE

$\begin{array}{lllllll}330 & 340 & 350 & 360 & 370 & 380 & 390\end{array}$

Seq. GenBank VP1 ALNLFFSPLEFOHLIENYGSIAPDALTVTISEIAVKDVTDKTGGGVOVTDSTTGRLCKLVDHEYKYPYVLGQG0DTLAPE 1198 Recombinante VP1 ALNLFFSPLEFOHLIENYGSIAPDALTYTISEIAYKDVTDKTGGGVQVTDSTTGRLCHLVDHEYKYPYYLGQGODTLAPE 1198

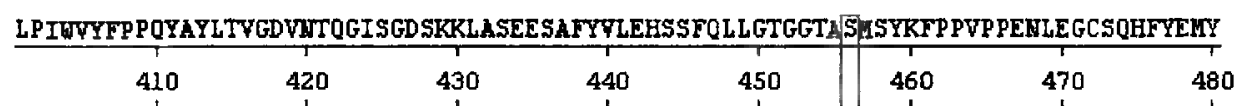

Seq. GenBenk YP1 LPIUVYFPPQYAYLTYGDVNTQGISGDSKKLASEE SAFYYLEHSSFOLLGTGGTh S 1SYKFPPVPPEHLEGCSOHFYEMY 1438

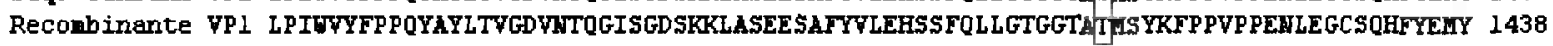

NPLYGSRLGWPDTLGGDPKFRSLTHEDHATQPQNFRPGPLVISYSTKEGDSSWTGAGKALTGLSTGTSQNTRISLRPGPY

$\begin{array}{lllllll}490 & 500 & 510 & 520 & 530 & 540 & 550\end{array}$

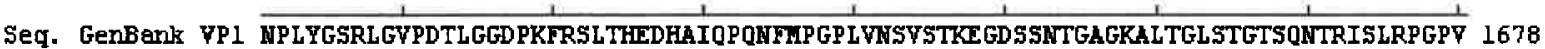
Recombinante VPI NPLYGSRLGVPTLGGDPKFRSLTHEDHAIQPOHFHPGPLVHSWSTKEGDSSHTGAGKALTGLSTGTSQNTRTSLRPGPV 16?8

SOPYHHWDTDKYYTGINAISHGQTTYGNAFDKRYQQGVGRFPMEKRQLKOLQGLMHHTY FPNKGTQQTTDQIERP LINGS

$\begin{array}{lllllll}570 & 580 & 590 & 600 & 610 & 620 & 630\end{array}$

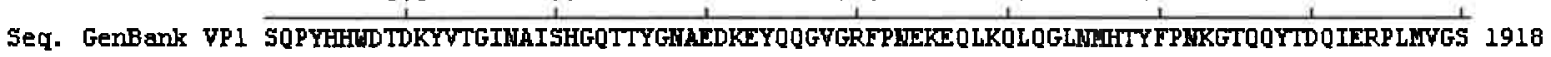

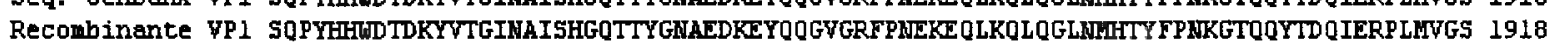

VWMRRALHYESQLUSKIPNLDDS FKTQFAALGGWGLHQPPPQIFLKIL PQSGPIGGIKSHGITTLYQYAVGIHTVTMTTK

$\begin{array}{llllllll}650 & 660 & 670 & 680 & 690 & 700 & 710 & 720\end{array}$

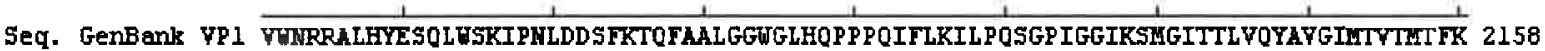
Recombinente YPI VWIRRALHYESQLUSKIPNLDDSFKTOFAALGGWGLHOPPPOIFLKILPQSGPIGGIKSHGITTLYOYAVGIMTVTMTFK 21.58

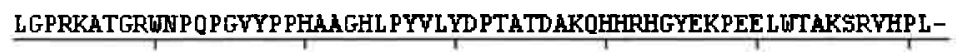

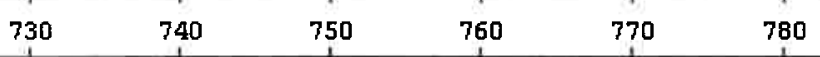

Seq. GenBank VPI LGPRKATGRINTPQPGYYP PHAAGHL PYPLYDPTATDAKOHHRHGYEKPEELWTAKSRYHPL.

Recombinante VP1 LGPRKATGRUNPQPGYYP PHAAGHL PYYLYDPTATDAKOHFRHGYEKPEELTTAKSRYHPL.

Figura 19 -Análise da seqüência da proteína recombinante VP1 que será produzida pelo clone GS115/pPIC9K-VP1 (781aa) e alinhamento com a seqüência de VP1 do vírus B19 (Ref. M13178, Shade et al., 1986) do GenBank. 


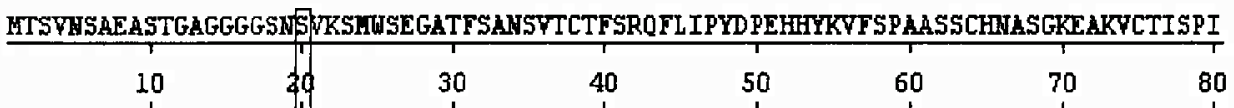

Seq. GenBenk VP2 MTSVWSAEASTGAGGGGSUS|VSMUSEGATFSANSVTCTFSRQFLIPYDPEHHYKVFS PAASSCHNASGKEAKVCTISPI $238 \mathrm{pb}$

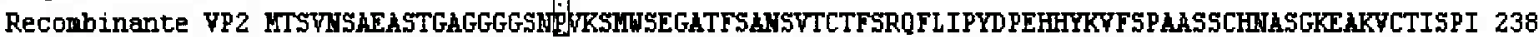

\section{MGYSTPWRYLDFALWLFFSLEFOHL IENYGSIAPDALTVTISEIAVKDVTDKTGGGYOVTDSTTGRLCMLYDHEYKYP}

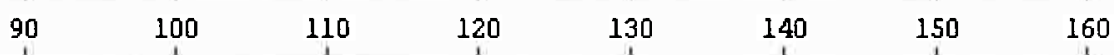

Seq. GenBank VP2 MGYSTPURYIDFWALNL FFSPLEFOHL IENYGSIKPDALTVTISEIAVKKWTDKTGGGVOVTDSTTGRLCNLVDHEYKYP Recombinante VP2 MGYSTPURYLDFHALNLFFSPLEFOHLIENYGSIAPDALTVTISEIAVKDVTDKTGGGYOVTDSTTGRLCNLVDHEYKYP 478

\section{MLGQGQDTLAPELPIWYTP PQYAYLTYGDWTOGISGDSKKLASEESAFYYLEHSSFOLLGTGGTASTISYKFPPVPPE}

$\begin{array}{lllllll}170 & 180 & 190 & 200 & 210 & 220 & 230\end{array}$

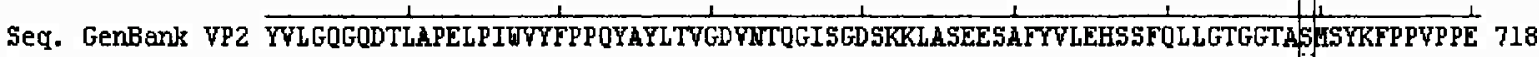
Recombinante VP2 YYLGQGQDTLAPELPIWYYTP POYYLTVGDWTOGISGDSKKLASEESAFTYLEHSSFOLLGTGGTALYISYKFPPVPPE 718

$$
\begin{aligned}
& \text { NLEGCSOHFYEMYNP LYGSRLGVPDTLGGD PKFRSLTHEDHAIQPQNFWPGPLVWSYSTKEGDSSWTGAGKALTGLSTGT } \\
& \begin{array}{llllllll}
250 & 260 & 270 & 280 & 290 & 300 & 310 & 320
\end{array}
\end{aligned}
$$

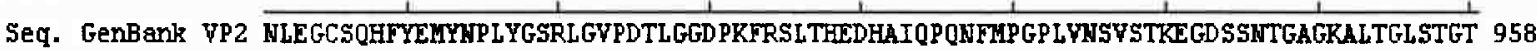
Recombinante VP2 NLEGCSOHFYEMYHPLYGSRLGVPDTLGGDPKFRSLTHEDHAIQPONFMPGPLWNSYSTKEGDSSNTGAGRLLTGLSTGT 958

SQNTRISLRPGPVSQPYHHWDTDKYTGINAISHGQTTYGNAEDKEYQQGVGRFPNEKEQLKQLQGLNMHTYYFPNKGTQQ

$\begin{array}{llllllll}330 & 340 & 350 & 360 & 370 & 380 & 390 & 400\end{array}$

Seq. GenBenk VP2 SONTRISLRPGPVSOPYHWDTDKYTTGINAISHGOTTYGNAEDKRYOOGVGRFPWEKEOLKOLOGLWMHTYFPMKGTOQ 1198 Recombinante VP2 SONTRISLRPGPSOPYHHDTDKYVTGIMAISHGQTTYGNAEDKEYQQGVGRFPNEKEOLKOLQGLNIHTYFPNKGTQO 1198

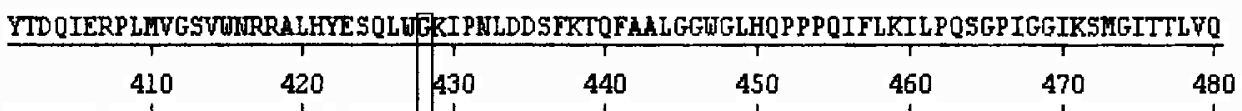

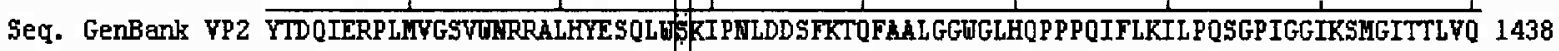

\begin{tabular}{|c|c|c|c|c|c|c|}
\hline 490 & 500 & 510 & 520 & 530 & 540 & 550 \\
\hline
\end{tabular}
Recombinante VP2 YTDQIERPLMVGSVUNRRALHYESQLUGKIPNLDDSFKTOFALLGGWGHOPPPOIFLKILPOSGPIGGIKSMGITTLVQ 1438

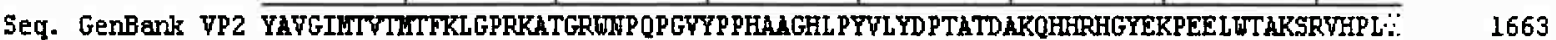
Recombinante VP2 YAVGIMTVTMTFKLGPRKATGRUDPQPGVYP PHAAGHL PYVL YDPTATDAKOHHRHGYEKPEELTTAKSRYHPL $\% 1$.

Figura 20 - Análise da seqüência da proteína recombinante VP2 que será produzida pelo clone GS115/pPIC9K-VP2 (654aa) e alinhamento com a seqüência de VP2 do vírus B19 (Ref. M13178, Shade et al., 1986) do GenBank. 


\subsection{Obtenção dos clones recombinantes de $P$. pastoris produtores de VP1 e VP2}

\subsubsection{Transformação da levedura $P$. pastoris com os vetores pPIC9K-VP1 e pPIC9K-VP2}

Os plasmídios recombinantes pPICK-VP1 e pPIC9K-VP2 foram linearizados com a enzima de restrição Sal I. Os fragmentos de DNA lineares foram empregados na transformação genética da linhagem $P$. pastoris GS115. As transformações foram realizadas por eletroporação. Os transformantes foram selecionados, por complementação gênica, em meio mínimo sem histidina, pelo fenótipo $\mathrm{His}^{+}$(Figura 21). Na Tabela 8, são apresentados os valores das eficiências de transformação obtidos para os vetores pPIC9K-VP1, pPIC9K-VP2 e pPIC9K.

4.5.2 Seleção dos clones recombinantes resistentes a altas concentrações de geneticina

Para a seleção dos clones portadores de um grande número de inserções dos vetores recombinantes, que, possivelmente, seriam ótimos produtores de VP1 e VP2 recombinantes; os transformantes foram analisados quanto à resistência a diferentes concentrações do antibiótico geneticina $\left(\mathrm{G} 418^{\mathrm{R}}\right.$ ) (Figuras 21 e 22).

Dentre as colônias de levedura $P$. pastoris GS115 transformadas com PPIC9K-VP1 e pPIC9K-VP2 obtidas, foram identificadas as que eram capazes de crescer em meio YPD sólido contendo geneticina $\mathrm{G} 418^{\mathrm{R}}$ em concentrações que variavam de 0,5 a $4 \mathrm{mg} / \mathrm{mL}$. Foi, também, empregado neste procedimento um clone transformante com o vetor vazio, denominado GS115/pPIC9K (controle negativo) (Figura 22). Este procedimento permitiu a seleção dos clones recombinantes que apresentavam melhor crescimento em meio sólido YPD $+4 \mathrm{mg} / \mathrm{mL}$ da droga Geneticina. 


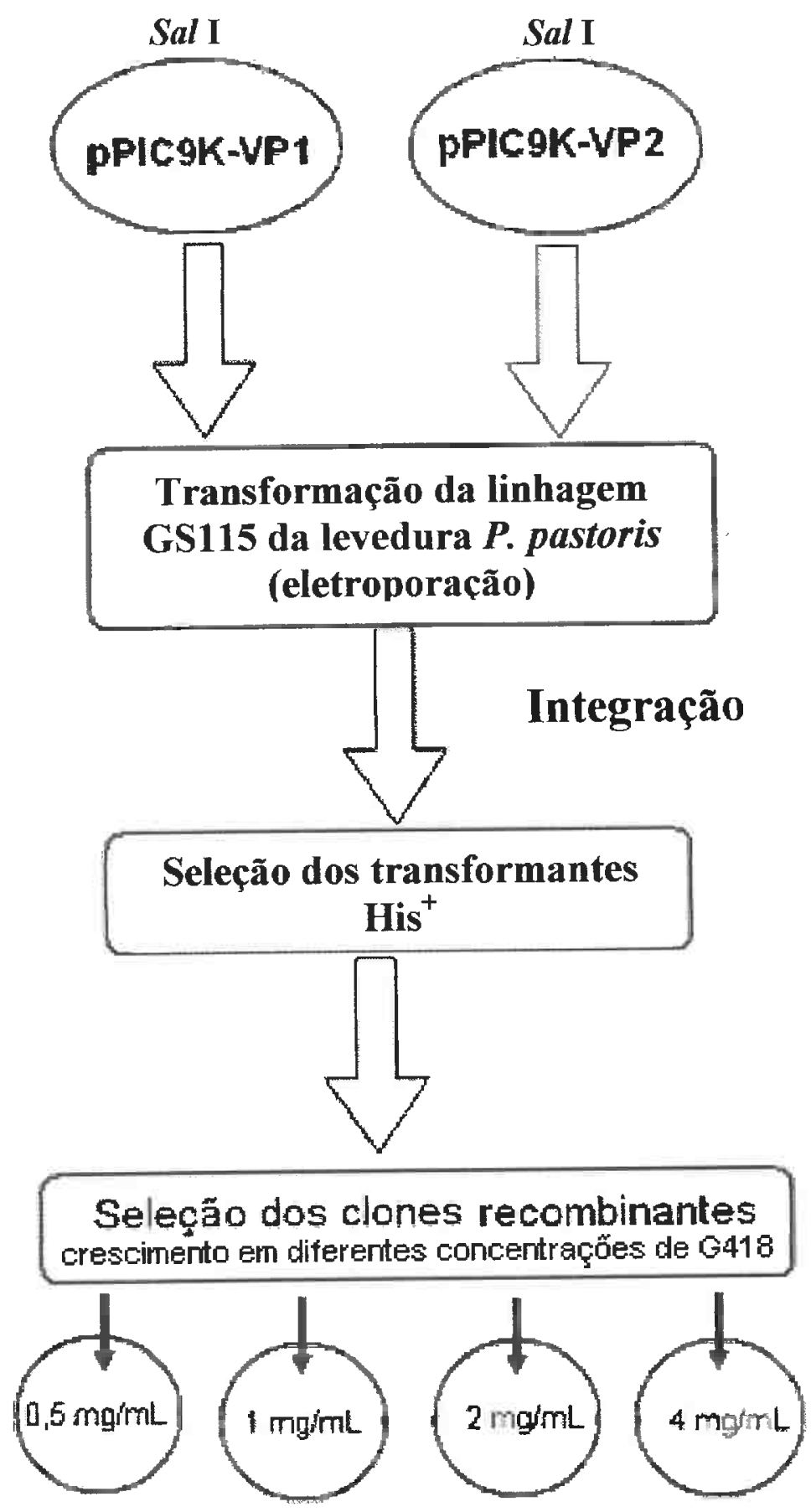

Figura 21 - Representação esquemática dos passos experimentais realizados para a obtenção dos clones recombinantes de $P$. pastoris expressando e secretando as proteínas VP1 e VP2 recombinantes. 
Tabela 8 - Eficiência de transformação, por eletroporação, de $P$. pastoris GS115 com os vetores pPIC9K-VP1, pPIC9K-VP2 e pPIC9K.

\begin{tabular}{cccc}
\hline Vetor & $\begin{array}{c}\text { Concentração de } \\
\text { plasmídio }(\mu \mathrm{g})\end{array}$ & $\begin{array}{c}\mathrm{N}^{\circ} \text { total de } \\
\text { transformantes obtidos }\end{array}$ & $\begin{array}{c}\text { Eficiência de transformação } \\
\text { (transformantes } / \mu \mathrm{g} \text { de } \\
\text { DNA plasmidial) }\end{array}$ \\
\hline pPIC9K-VP1 & 10 & 24 & 2,4 \\
pPIC9K-VP2 & 8 & 13 & 1,5 \\
pPIC9K & 10 & 109 & 10,9 \\
\hline
\end{tabular}

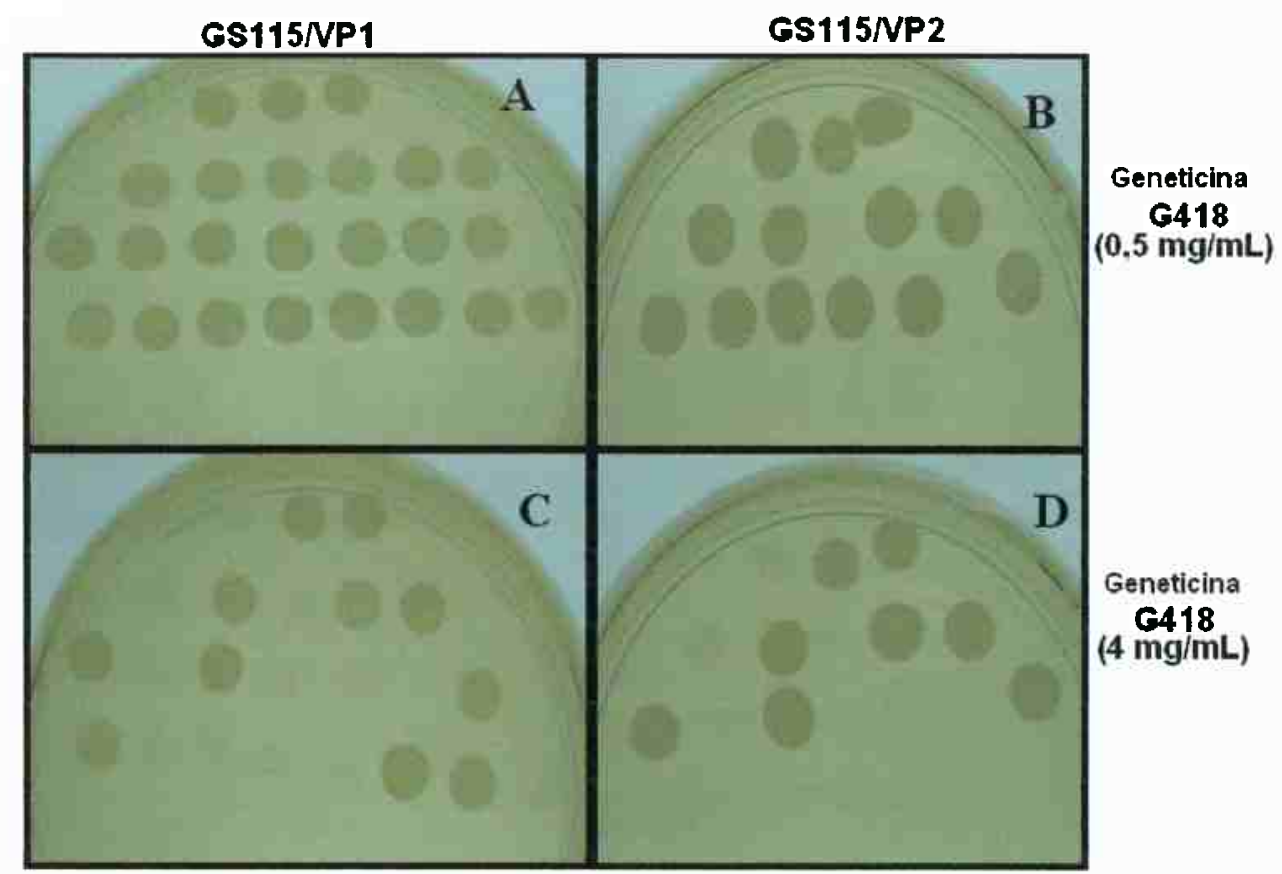

Figura 22 - Clones da levedura $P$. pastoris recombinantes GS115/pPIC9K-VP1 (A e C); e GS115/pPIC9K-VP2 (B e D). Os cultivos foram realizados em meio sólido YPD + geneticina G418, nas concentrações de $0,5 \mathrm{mg} / \mathrm{mL}$ (A e B) e $4 \mathrm{mg} / \mathrm{mL}$ (C e D). 
O crescimento de todos os clones recombinantes pré-selecionados foi analisado em meio líquido YPD + geneticina $(4 \mathrm{mg} / \mathrm{mL})$.

Estas estratégicas permitiram a seleção dos melhores clones recombinantes, que apresentavam ótimo crescimento em elevadas concentrações de geneticina. Esta característica foi tomada como indicativo de que estes clones eram portadores das múltiplas inserções cromossomais desejadas (Tabela 9).

Tabela 9 - Clones recombinantes resultantes da linhagem $P$. pastoris GS115/pPIC9K-VP1, GS115/pPIC9K-VP2 e GS115/pPIC9K (controle negativo), resistente a $4 \mathrm{mg} / \mathrm{mL}$ de geneticina, selecionados para os ensaios de produção de VP1 e VP2 recombinantes.

\begin{tabular}{lcc}
\hline \multicolumn{2}{c}{ Clones recombinantes } \\
\hline GS115/pPIC9K-VP1 13 & GS115/pPIC9K & GS115/pPIC9K-VP2 2 \\
GS115/pPIC9K-VP1 $1_{16}$ & & GS115/pPIC9K-VP2 \\
GS115/pPIC9K-VP1 $1_{19}$ & & GS115/pPIC9K-VP2 ${ }_{10}$ \\
GS115/pPIC9K-VP1 $1_{20}$ & \\
\hline
\end{tabular}

\subsubsection{Seleção dos clones recombinantes ótimos produtores de VP1 e VP2}

Para a obtenção das proteínas recombinantes VP1 e VP2 produzidas pelos clones recombinantes $P$. pastoris, primeiramente foram realizados cultivos em frascos erlenmeyers agitados "Shaker" (Mat. Métodos item 3.17).

Na Figura 23 é apresentada a alta densidade celular obtida por este procedimento, juntamente com a D.O. alcançada pelos clones recombinantes GS115/pPIC9K-VP1 $1_{13}$; GS115/pPIC9K-VP1 $19 ;$ GS115/pPIC9K-VP2 $25 ;$ GS115/pPIC9K-VP2 $2_{10}$ e GS115/pPIC9K (controle). 


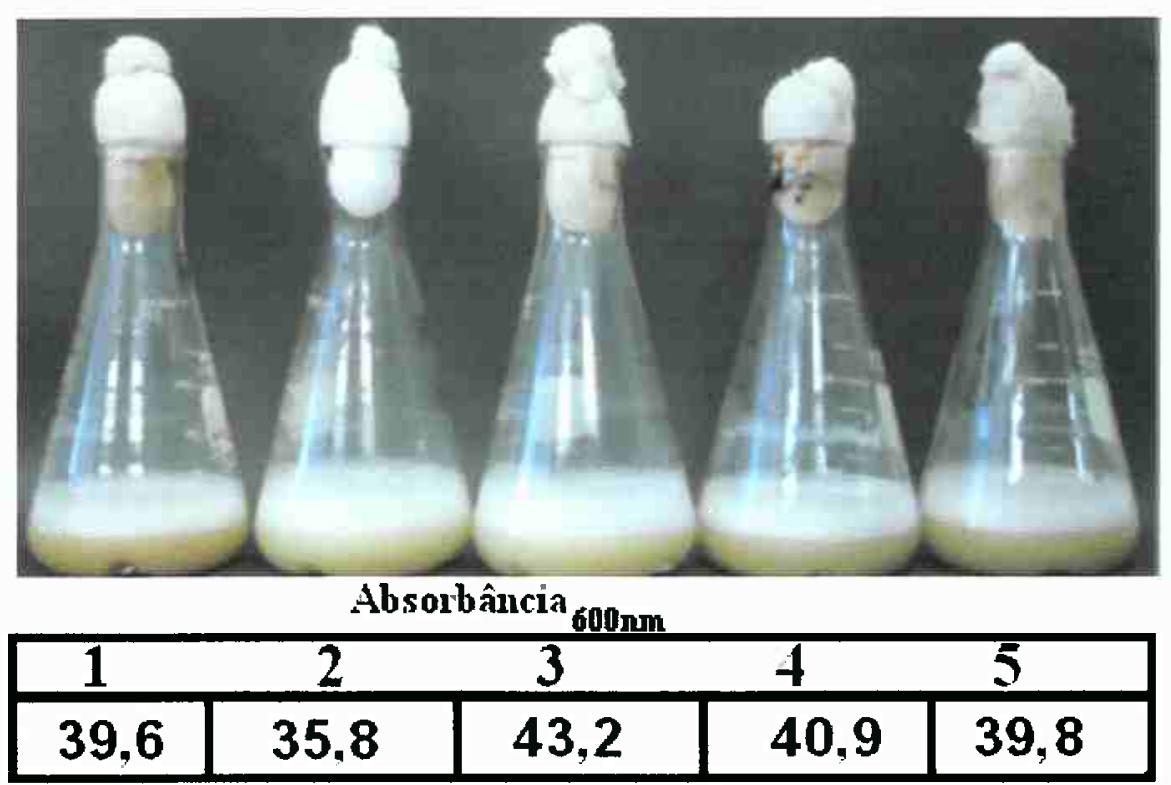

Figura 23 - Frascos erlenmeyers contendo culturas de $P$. pastoris GS115 recombinantes crescidas em meio MD glicerol (34 horas) e subseqüente indução de proteína recombinante com metanol (96 horas), submetidos a agitação em "shaker", a $30^{\circ} \mathrm{C}$ : 1 e 2) GS115/pPIC9KVP1 clones 13 e 19 respectivamente; 3 e 4) GS115/pPIC9K-VP2 clones 5 e 10 respectivamente; 5) GS115/pPIC9K.

A análise das proteínas VP1 e VP2 recombinantes expressas pelos clones selecionados, foi realizada em gel de SDS-PAGE (Mat. Métodos, item 3.25). Para tanto, o extrato bruto dos sobrenadantes das culturas foram concentrados e submetidos à análise em gel de poliacrilamida desnaturante (Figura 24). Os clones pPIC9K-VP1 13 (coluna 1), pPIC9K$\mathrm{VP1}_{19}$ (coluna 3), pPIC9K-VP2 5 (coluna 6) e pPIC9K-VP2 10 (coluna 7) expressam quantidades significativas das proteínas recombinantes correspondentes às bandas esperadas para VP1 (84 kDa) e VP2 (58 kDA), respectivamente. O controle negativo, clone GS115/pPIC9K (coluna 8) não expressa proteínas com estas propriedades. 


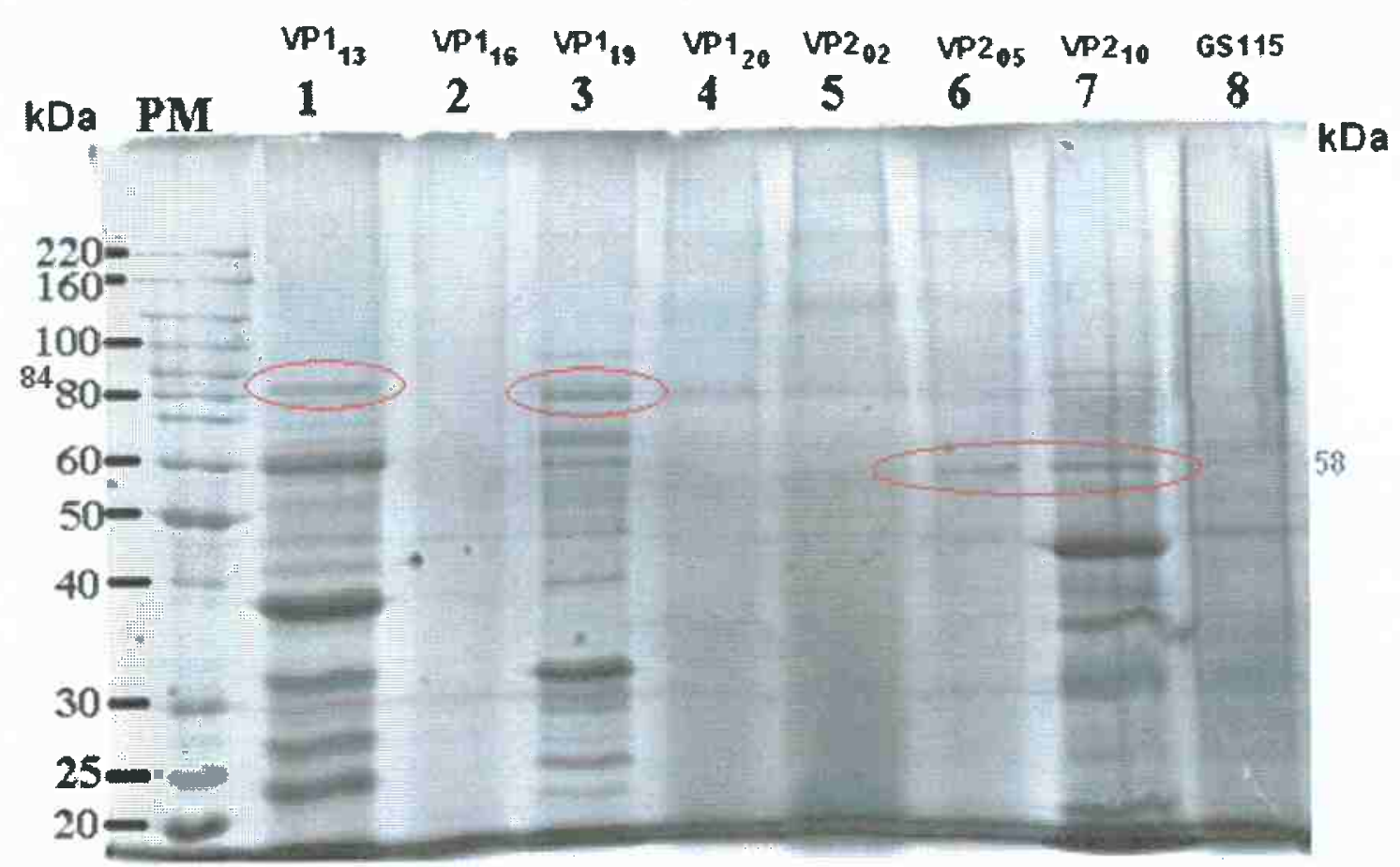

Figura 24 - Gel de SDS-poliacrilamida 12,5\%, após corrida eletroforética e coloração com "Coomassie Blue R250". Os clones recombinantes foram cultivados em frascos agitados em "shaker" contendo meio YPG (34 horas) e indução por metanol, por 96 horas. O extrato bruto do sobrenadante foi concentrado, utilizando-se o "kit" concentrador "MILLIPORE" "Ultrafree ${ }^{R}-15$ Centrifugal Filter Devise Biomax 30K": PM: marcador do peso molecular de proteína ( $\mathrm{kDa})$, Invitrogen $(0,5 \mu \mathrm{g})$ : 1) GS $115 / \mathrm{pPIC} 9 \mathrm{~K}-\mathrm{VP} 1_{13}$; 2) GS115/pPIC9K-VP $1_{16}$; 3) GS $115 / \mathrm{pPIC} 9 \mathrm{~K}-\mathrm{VP} 1_{19}$; 4) GS $115 / \mathrm{pPIC} 9 \mathrm{~K}-\mathrm{VP}_{20}$; 5) GS115/pPIC9K-VP $2_{02}$; 6) GS115/pPIC9K-VP2 $2_{05}$; 7)GS115/pPIC9K-VP2 $10 ; 8$ ) GS115/pPIC9K (controle negativo).

Estas análises permitiram a seleção dos clones recombinantes GS115/pPIC9K-VP $1_{13}$ e GS115/pPIC9K-VP1 $1_{19}$; e, GS115/pPIC9K-VP2 $2_{05}$ e GS115/pPIC9K-VP2 ${ }_{10}$, para as etapas subseqüentes de produção das proteínas recombinantes VP1 e VP2, respectivamente. 


\subsubsection{Curva de crescimento dos clones selecionados}

Os clones recombinantes selecionados foram avaliados quanto ao crescimento em meio YPG. mediante a obtenção da curva de crescimento por 12 horas. (Figura 25).

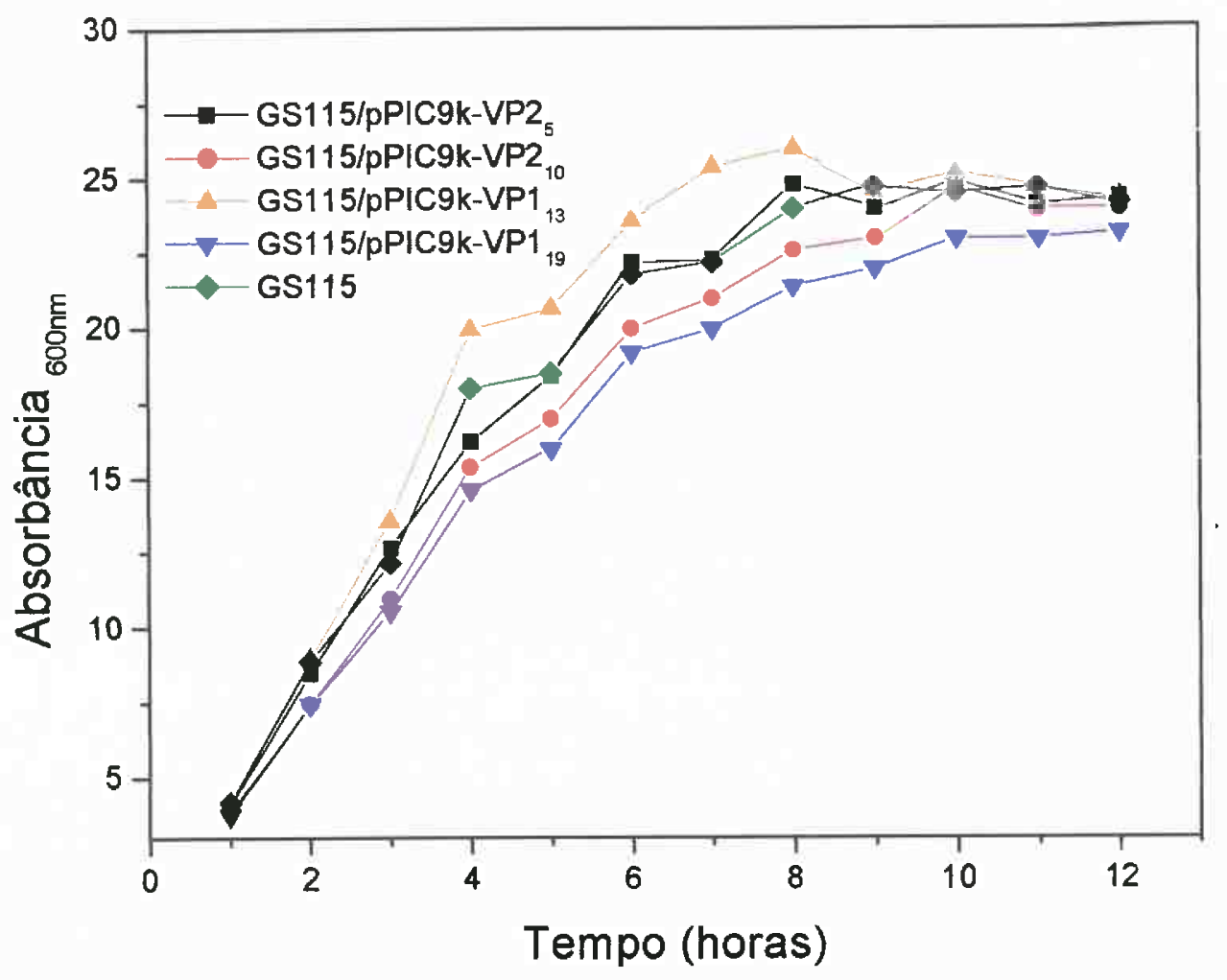

Figura 25 - Curva de crescimento dos clones recombinantes da linhagem P. pastoris GS115 obtidas com os plasmídios pPIC9K-VP1, pPIC9K-VP2 e linhagem original GS115. Os cultivos foram realizados em meio líquido YPG, em frascos erlenmeyers com haletas, com aeração, a $30^{\circ} \mathrm{C}$.

Este procedimento permitiu a constatação de que os clones recombinantes produtores de VP1 recombinante (GS115/pPIC9K-VP1 13 e GS115/pPIC9K-VP1 $1_{19}$ ) e os clones selecionados que expressam VP2 recombinante (GS115/pPIC9K-VP2 $2_{05}$ e GS115/pPIC9KVP2 $2_{10}$ ) cresceram tão bem quanto a linhagem original GS115, quando cultivados nas mesmas condições. 


\subsection{Produção das proteínas recombinantes VP1 e VP2 em biorreator de 4 litros}

\subsubsection{Cultivo em biorreator de 4 litros}

Os resultados apresentados na análise do SDS-PAGE permitiram selecionar os clones recombinantes de $P$. pastoris GS115/pPIC9K-VP1 13, GS115/pPIC9K-VP1 19 , e GS115/pPIC9K-VP2 $2_{10}$ capazes de expressar e excretar as proteínas recombinantes VP1 e VP2, para a expressão em biorreator.

O crescimento dos clones recombinantes realizados em biorreator de 4 litros, foram monitorados por 28 horas. A cada 2 horas foi medida a $\mathrm{Ab}_{600}$ (Figura 26). Esse intervalo de tempo corresponde a fase inicial de crescimento com $4 \%$ de glicerol (24 horas), seguida da etapa de alimentação por 4 horas com $40 \%$ de glicerol. Após essa etapa iniciou-se a fase de alimentação com metanol a 100\%.(Material e Métodos, item 3.21).

Os valores de concentração celular, biomassa e massa seca das culturas dos clones recombinantes de $P$. pastoris estão apresentados na Tabela 10.

Na Figura 27 é demonstrada a alta densidade celular obtida no final do cultivo fermentação do clone recombinante GS1 15/pPIC9K-VP1 13 . 


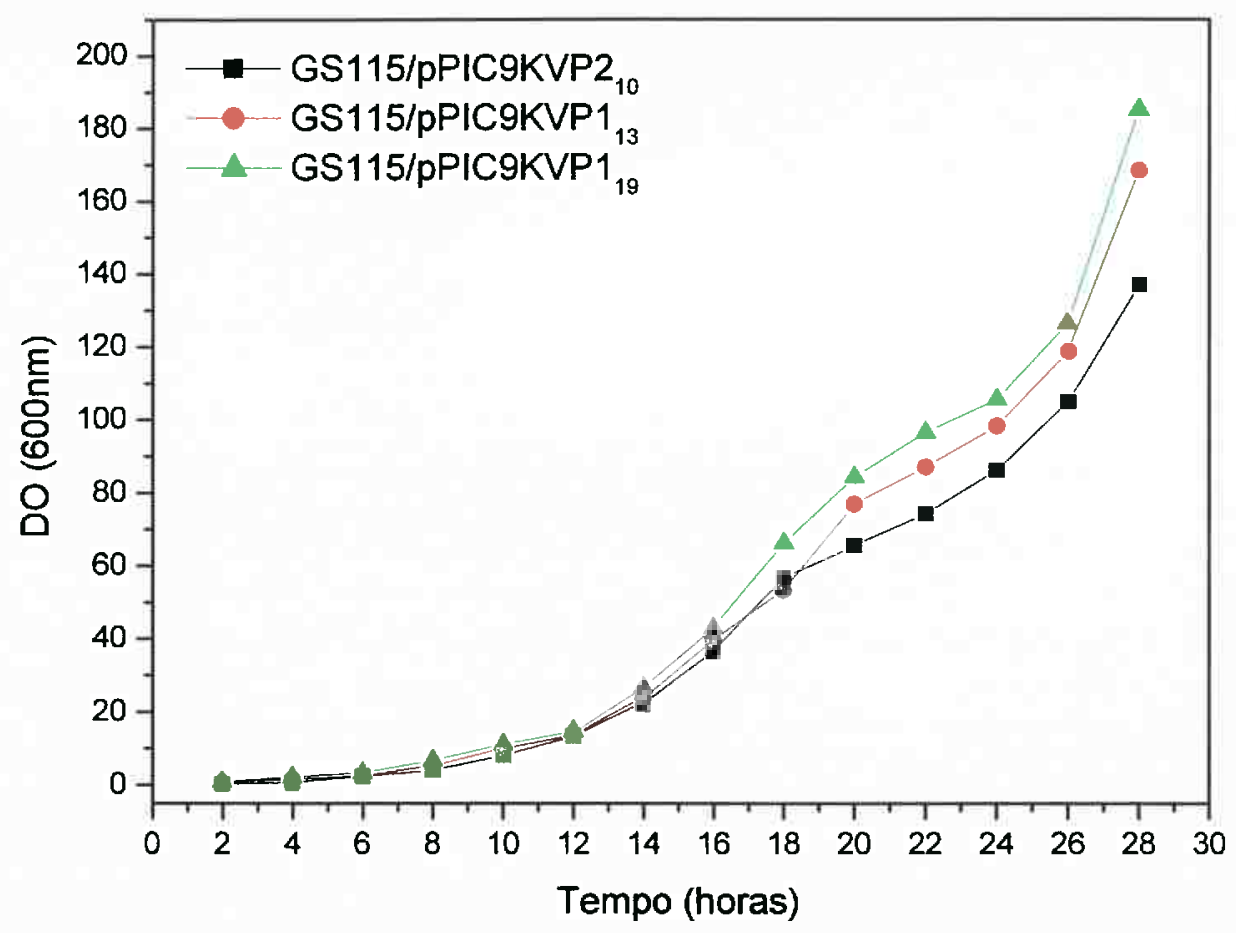

Figura 26 - Curva de crescimento dos clones recombinantes, GS115/pPIC9K-VP $1_{13}$, GS115/pPIC9KVP $1_{19}$, e GS115/pPIC9K-VP2 ${ }_{10}$ em meio de cultura FM22, no biorreator de 4 litros, com $35 \%$ de aeração e temperatura a $30^{\circ} \mathrm{C}, \mathrm{pH} 5,5$ monitorado por 28 horas.

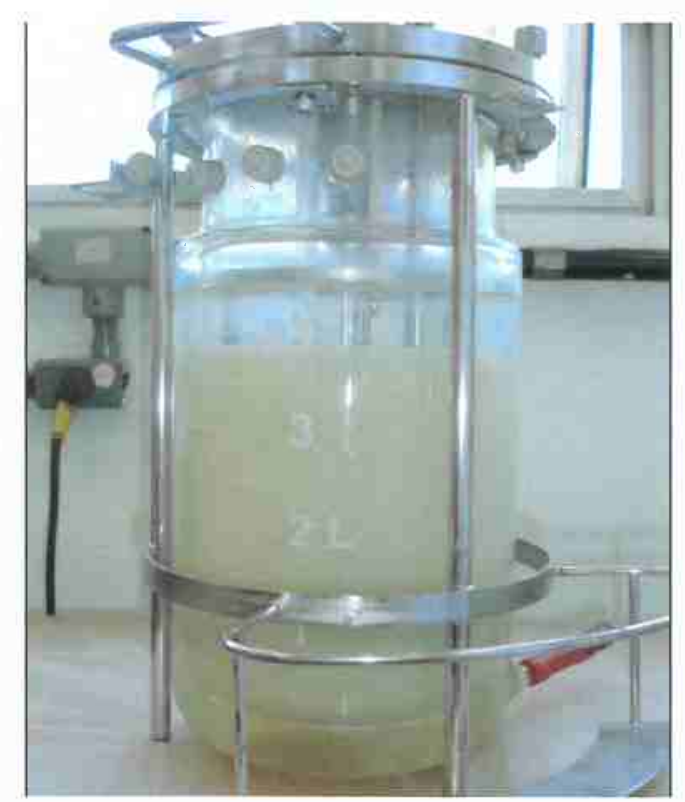

Figura 27 - Cultura crescida em biorreator de $4 \mathrm{~L}$, do clone recombinante de $P$. pastoris GS115/pPIC9K-VP1 $1_{13}$, em meio FM22, com $35 \%$ de aeração e temperatura a $30^{\circ} \mathrm{C}$, pH 5,5 após 126 horas. 
Tabela 10 - Dados da massa úmida e biomassa das culturas dos clones recombinantes de $P$. pastoris obtidos em biorreator de 4 litros.

\begin{tabular}{lcc}
\hline Clone recombinante & $\begin{array}{c}\text { Biomassa } \\
\text { (g de peso úmido/L) }\end{array}$ & $\begin{array}{c}\text { Volume de biomassa na cultura } \\
(\%)\end{array}$ \\
\hline GS115/pPIC9K-VP1 13 & 240 & 36 \\
GS115/pPIC9K-VP1 19 & 228 & 32 \\
GS115/pPIC9K-VP2 & 236 & 35 \\
\hline
\end{tabular}

4.6.2 Análise da morfologia das células do clone recombinante GS115/pPIC9KVP $1_{13}$, antes e depois da indução por metanol

A Figura 28 apresenta duas fotomicrografias do crescimento celular do clone recombinante pPIC9K-VP1 $1_{13}$ isolado do biorreator durante a fase de cultivo após 24 horas de crescimento em meio YPG (contendo glicerol como fonte de carbono) (A), e após 96 horas de indução de expressão da proteína heteróloga em meio de YPM (contendo metanol com principal fonte de carbono) (B).

Pode-se observar que durante o cultivo em YPG (A), a maioria das células apresentam brotamento, por se encontrarem em fase exponencial de crescimento; enquanto que em YPM (B), o brotamento está presente, relativamente, em menor porcentagem das células. Todavia, durante todo o processo não se observa evidências de que as células estejam submetidas a uma condição de estresse. 


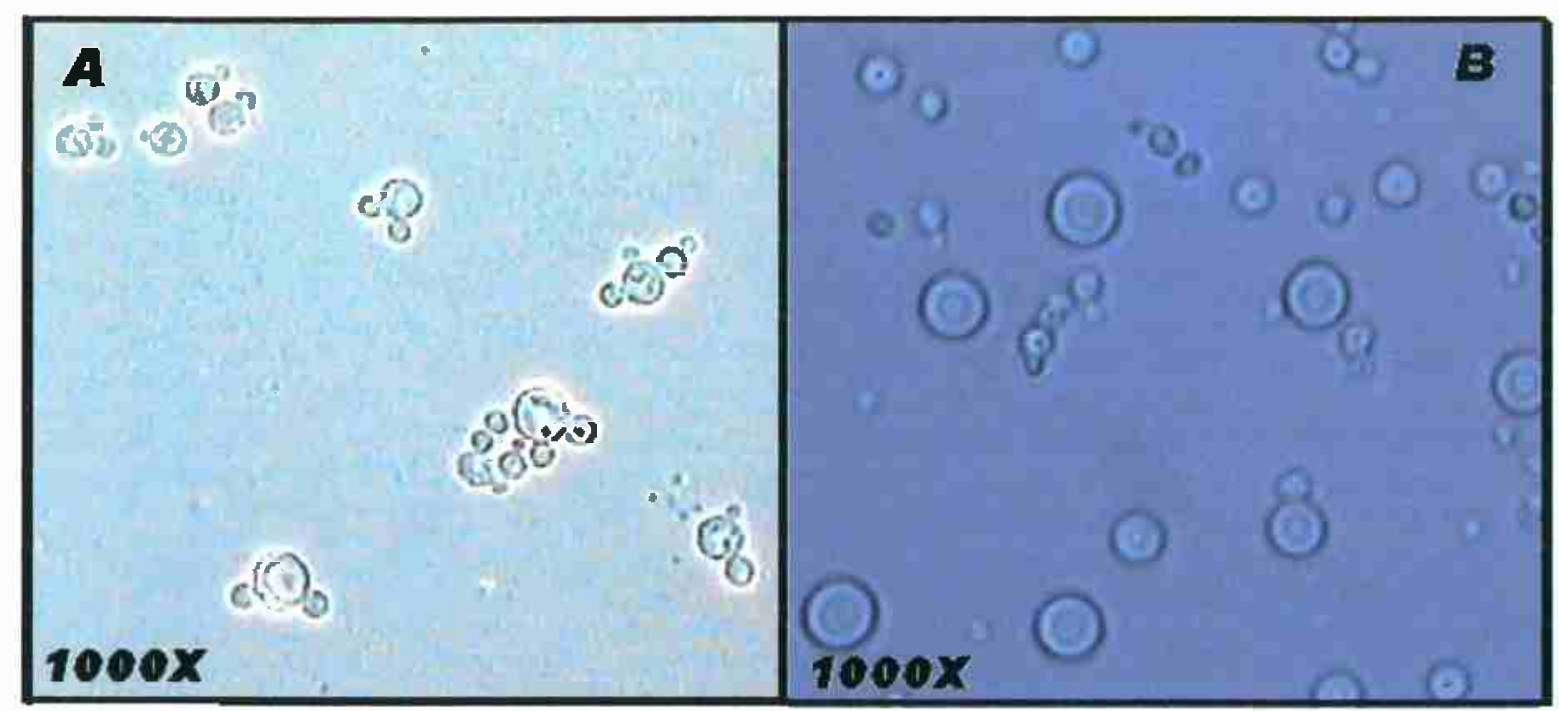

Figura 28 - Células do clone recombinante GS115/pPIC9K-VP1 $1_{13}$ isoladas de cultura em biorreator de 4 litros (microscopia óptica com aumento de 1000X): A) crescimento em meio YPG, após 36 horas de cultivo, a $30^{\circ} \mathrm{C}$; B) após 96 horas de indução com metanol.

\subsection{Análise dos Antígenos VP1 e VP2}

As atividades biológicas dos antígenos recombinantes VP1 e VP2 foram analisadas empregando-se as técnicas imunológicas; ELISA, Dot-Blot e Western Blot.

\subsubsection{Frente anticorpo anti-B19, por "Dot-Blot"}

Após a obtenção dos antígenos recombinantes VP1 e VP2, proveniente dos clones $P$. pastoris recombinantes GS115/pPIC9K-VP1 13 e GS115/pPIC9K-VP2 $2_{10}$, estes foram testados frente ao soro comprovadamente positivo para o vírus B19 e soro normal (controle negativo), ambos provenientes do Laboratório de Virologia Clínica Molecular do Instituto de Ciências Biomédicas da Universidade de São Paulo, empregada a técnica "Dot-Blot", na membrana de nitrocelulose foram incorporados $20,0 \mu \mathrm{g} / \mathrm{mL}$ do antígeno VP1 e $15,0 \mu \mathrm{g} / \mathrm{mL}$ de VP2, ambos parcialmente purificados (Mat. Métodos item 3.22.).

$\mathrm{Na}$ Figura 29 podem ser observados o sucesso dos dois antígenos recombinantes construídos neste trabalho, VP1 e também VP2, em detectar o soro de pessoas infectadas com o vírus B19. 

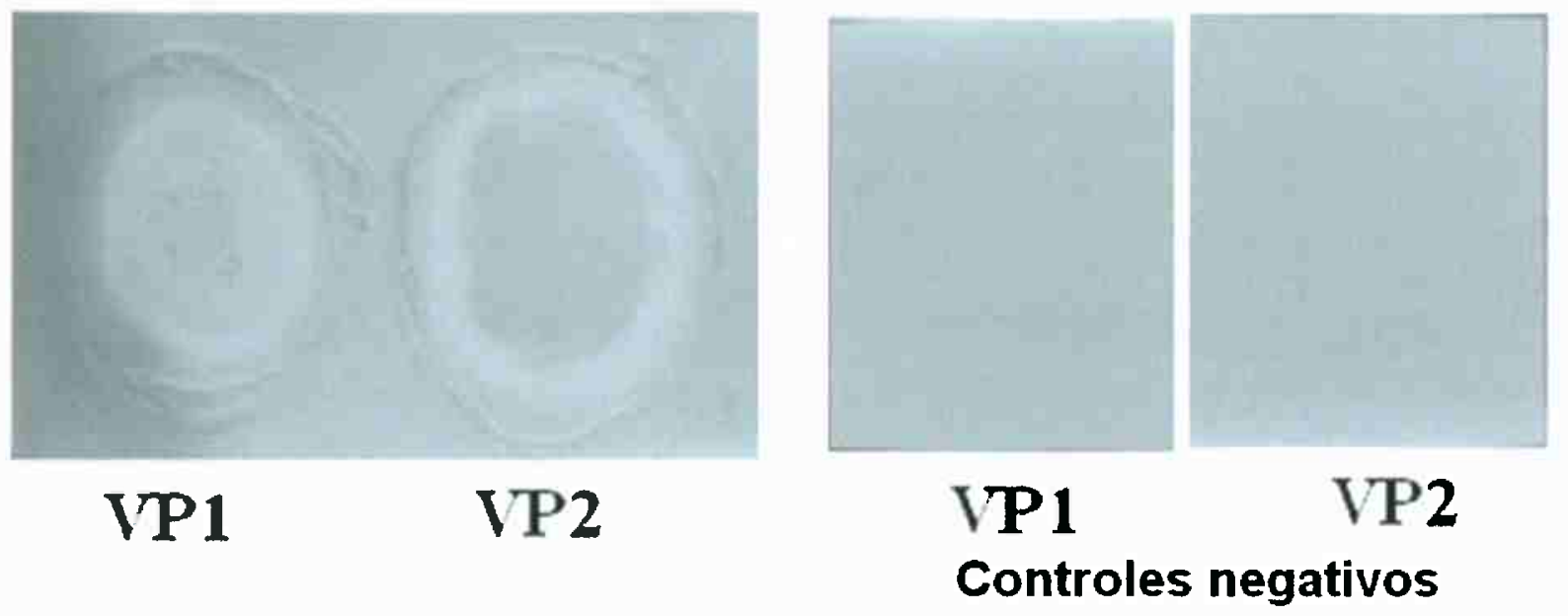

Figura 29 - Análise dos antígenos VP1 e VP2 pela reação de "Dot-Blot" frente ao soro positivo para vírus $\mathrm{B} 19$, como controle negativo foi usado soro normal.

\subsubsection{Frente ao anticorpo anti-B19, por ensaio imunoenzimático ELISA}

Os antígenos recombinantes VP1 e VP2, produzidos pelos clones $P$. pastoris recombinantes foram avaliados, por ELISA contra soro humano comprovadamente positivo para o vírus $\mathrm{B} 19$, para detecção de anticorpos contra vírus B19. Como controle negativo foi usado soro de pessoa normal não infectada. As reações de ELISA foram feitas em placas com 96 poços, sensibilizadas com o sobrenadante VP1 $(20,0 \mu \mathrm{g} / \mathrm{mL})$ e VP2 $(15,0 \mu \mathrm{g} / \mathrm{mL})$. Os resultados apresentados nas Figuras 30 a 33 demonstram que as reações foram positivas quando comparadas com o soro controle. 


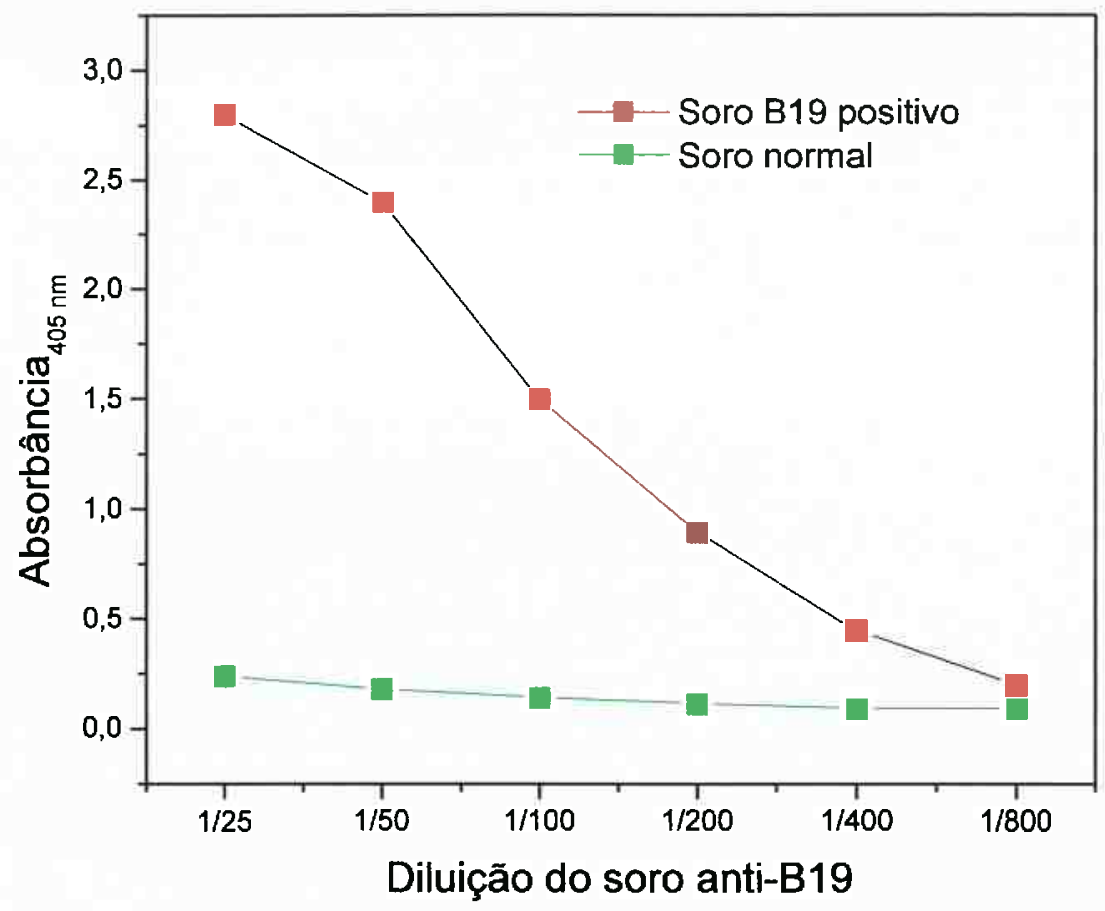

Figura 30 - Análise do antígeno VP1 $(20 \mu \mathrm{g} / \mathrm{mL})$ sobrenadante da cultura GS1 $15 / \mathrm{pPIC} 9 \mathrm{~K}-\mathrm{VP} 1_{13}$, frente ao soro positivo para vírus B19 e frente ao soro normal.

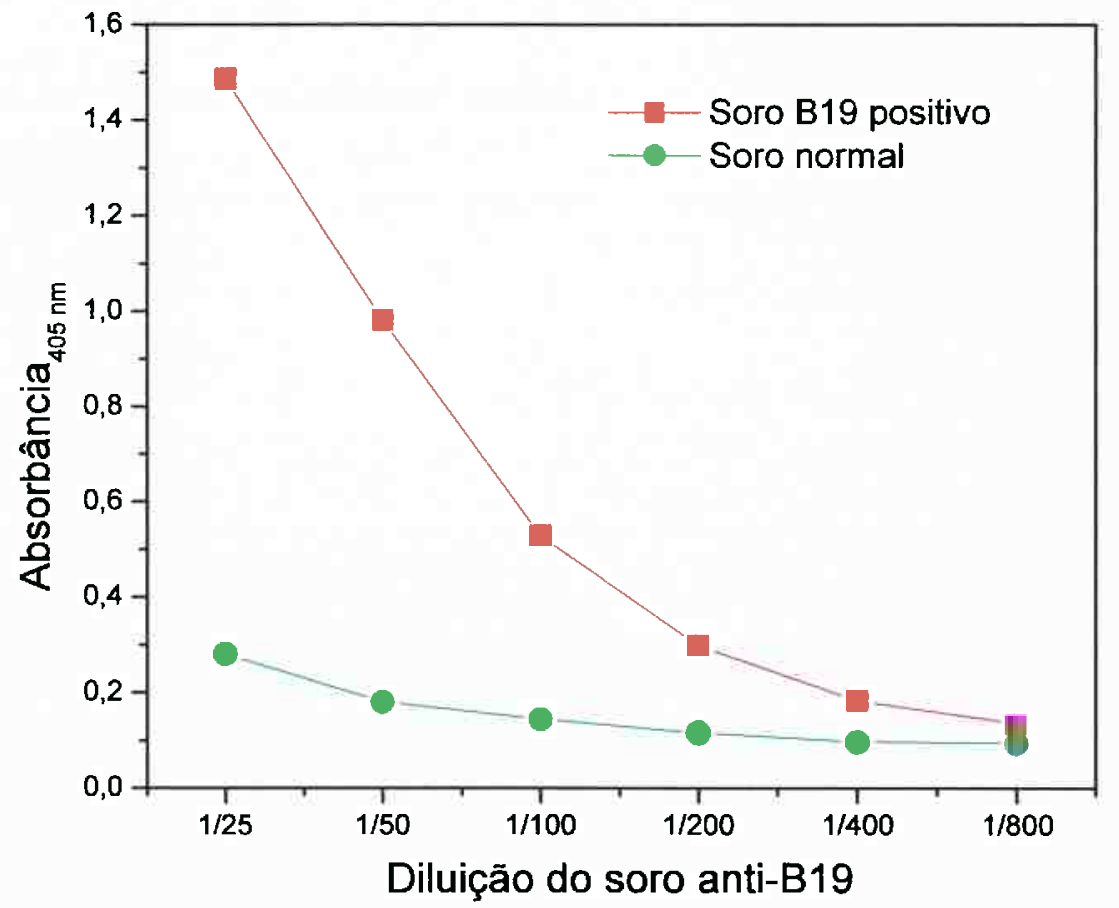

Figura 31 - Análise do antígeno VP1 $(25 \mu \mathrm{g} / \mathrm{mL})$ semi-purificado, frente ao soro positivo para o vírus B19 e soro normal. 


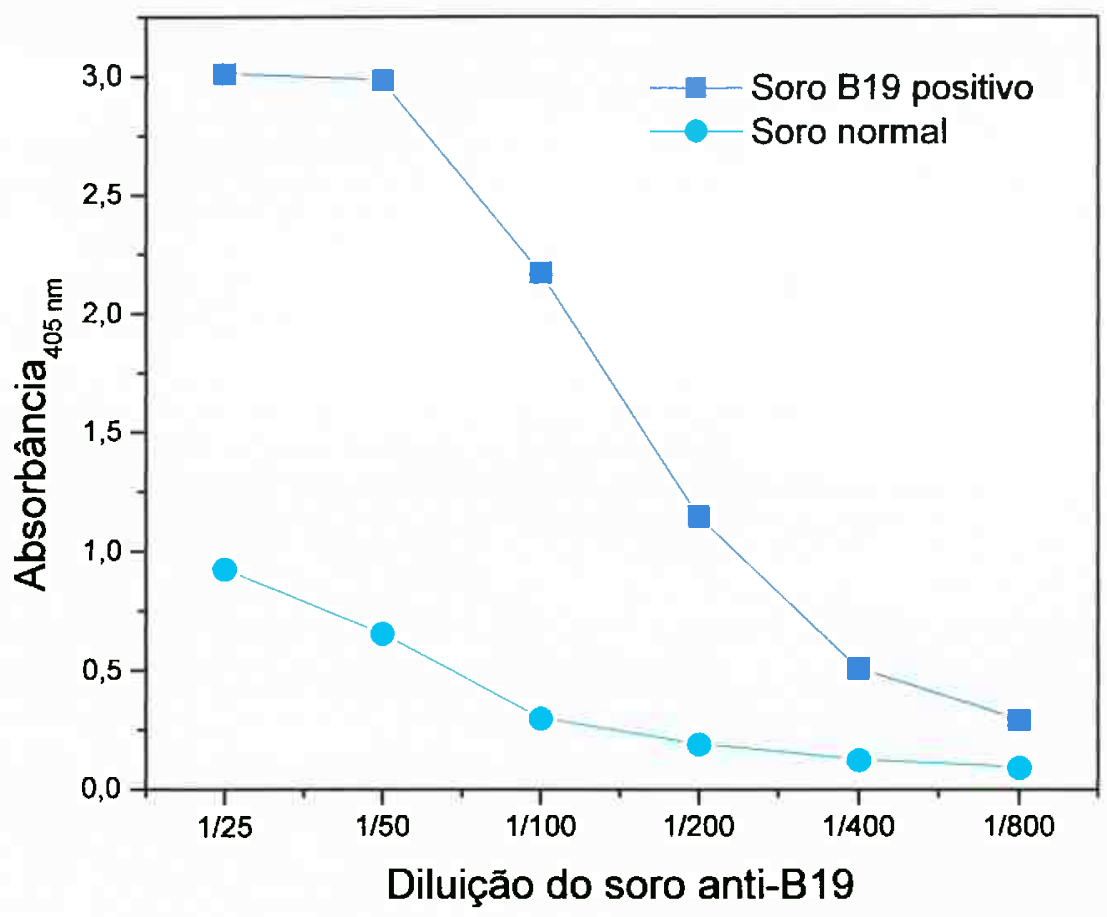

Figura 32 - Análise do antígeno VP2 ( $15 \mu \mathrm{g} / \mathrm{mL}$ ) sobrenadante da cultura GS115/pPIC9K-VP2 ${ }_{10}$, frente ao soro positivo para vírus B19 e frente ao soro normal.

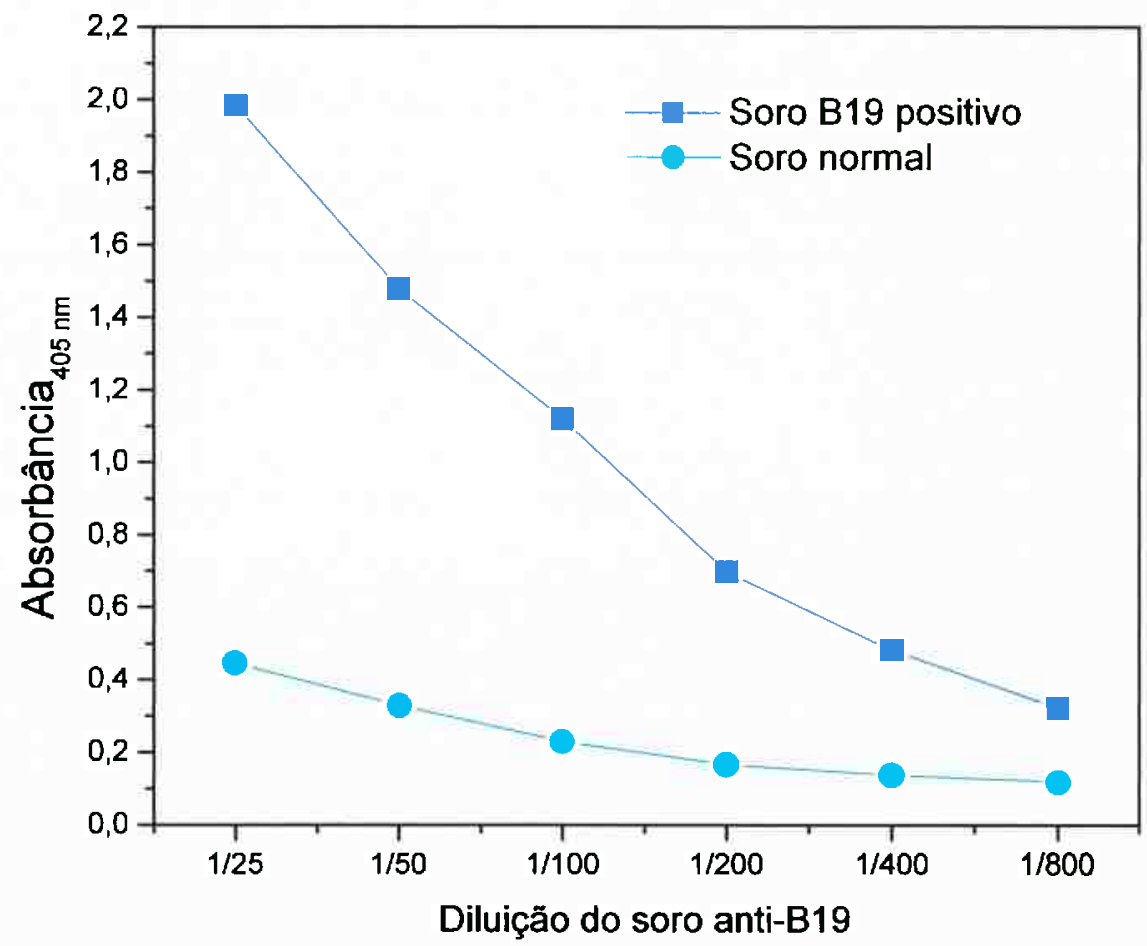

Figura 33 - Análise do antígeno VP2 $(10 \mu \mathrm{g} / \mathrm{mL})$ semi-purificado, frente ao soro positivo para o vírus $\mathrm{B} 19 \mathrm{e}$ frente ao soro normal. 
Os ensaios de ELISA para titulação de anticorpos frente aos antígenos recombinantes VP1 e VP2 evidenciaram que o antígeno recombinante VP2 apresenta maior valor de título, quando comparado com o antígeno recombinante VP1 (Figura 34). Quando os valores dos títulos de anticorpos obtidos frente aos dois antígenos foram submetidos, a razão entre o valor positivo do título e o obtido no controle (soro normal), foi observado uma inversão nesses resultados (Figura 35). Esses dados sugerem que o título obtido frente o antígeno recombinante VP1 é mais expressivo que o determinado frente o antígeno recombinante VP2.

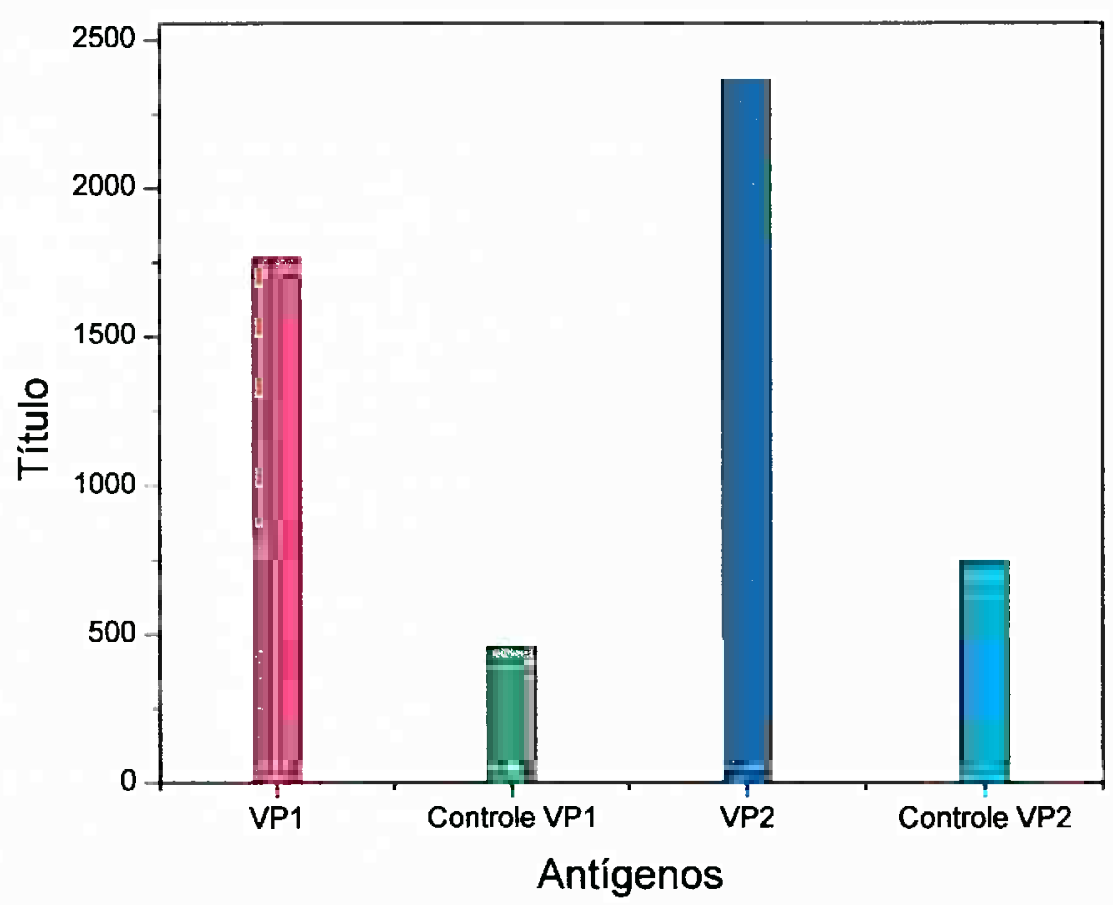

Figura 34 - Títulos de anticorpos frente aos antígenos recombinantes VP1 e VP2, como controle soro humano normal. 


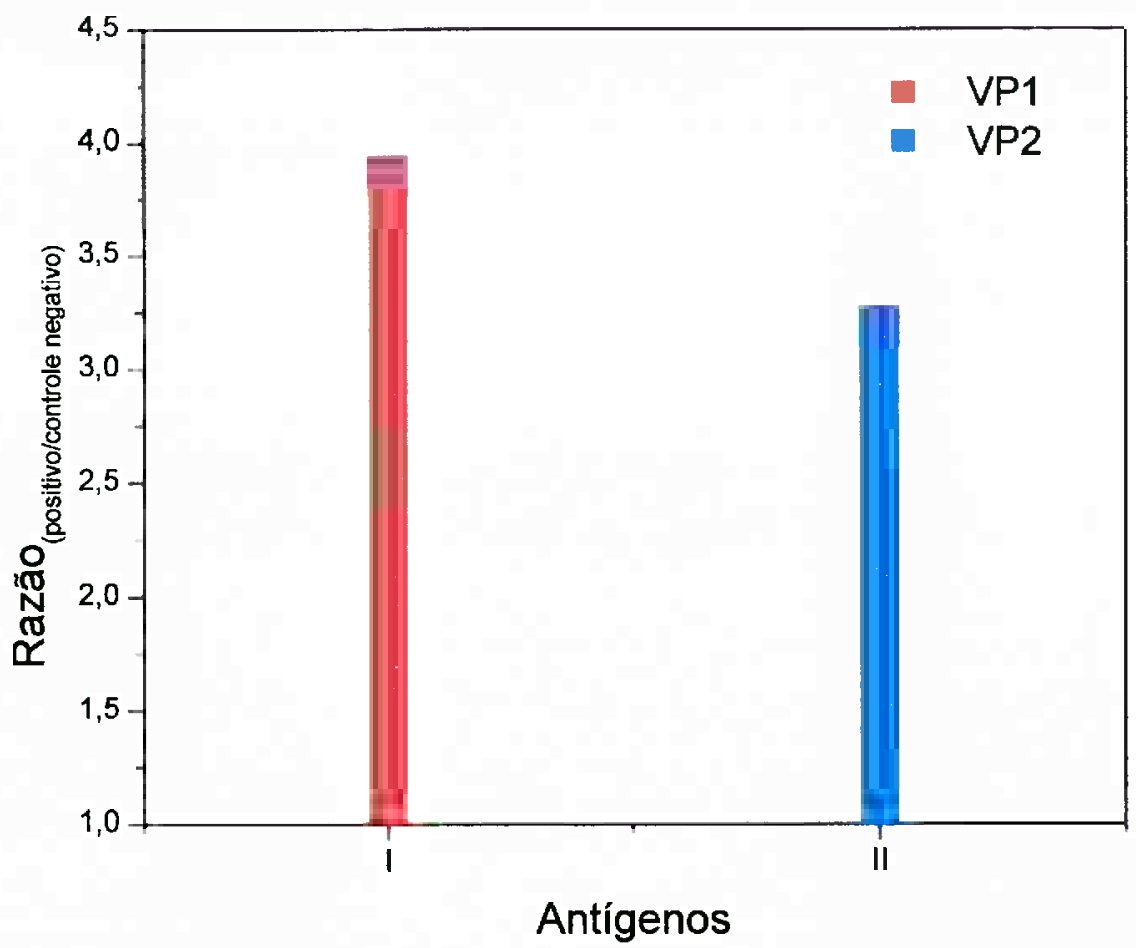

Figura 35 - Razão entre os títulos de VP1 recombinante/controle VP1, e VP2 recombinante/controle VP2: I-VP1 e II - VP2.

\subsubsection{Frente anticorpo anti-B19, por ensaio do Immunoblotting}

Os antígenos dos sobrenadantes foram utilizados em ensaios de SDS-PAGE. Foram empregados aproximadamente por caneleta, 3,5 $\mu \mathrm{g}$ e 3,0 $\mu \mathrm{g}$ dos recombinantes VP1 e VP2, respectivamente. Os resultados apresentaram a expressão de um fragmento protéico de aproximadamente $84,0 \mathrm{kDa}$ para o antígeno VP1 e outro de $58 \mathrm{kDa}$ correspondente ao VP2 (Figura 36). 


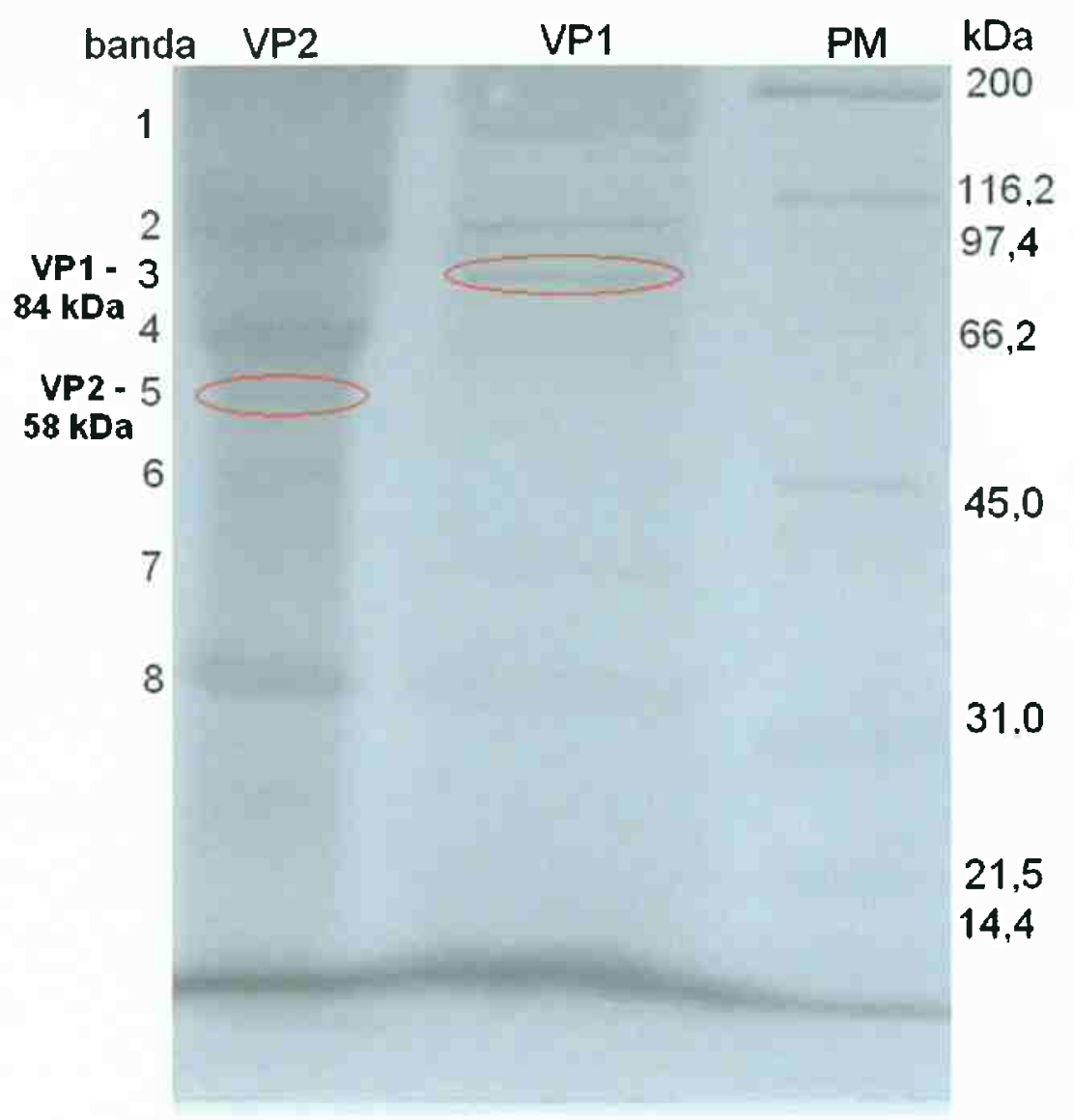

Figura 36 - SDS-Poliacrilamida $10 \%$, submetido a corrida eletroforética e coloração com "Coomassie Blue". Perfis das proteínas dos sobrenadantes dos cultivos dos clones recombinantes produtores de VP1 e VP2. Foram empregados 3,5 $\mu \mathrm{g}$ de VP1 e 3,0 $\mu \mathrm{g}$ de VP2: PM, marcador do peso molecular de proteína (kDa) "BIO-RAD" $(2 \mu \mathrm{g}) ; 1$, antígeno VP1; 2 , antígeno VP2.

Para confirmar a sensibilidade dos antígenos recombinantes VP1 e VP2 frente ao soro humano comprovadamente positivo para o vírus B19, foi realizada uma corrida eletroforética em SDS-PAGE. Após a separação das bandas protéicas, foi realizado a transferência para membrana de nitrocelulose ("Western Blotting") e realizada a revelação pela adição do conjugado anti-IgG fosfatase de humano. Os resultados observados na membrana apresentaram bandas correspondentes aos esperados para os dois antígenos (Figura 37). 


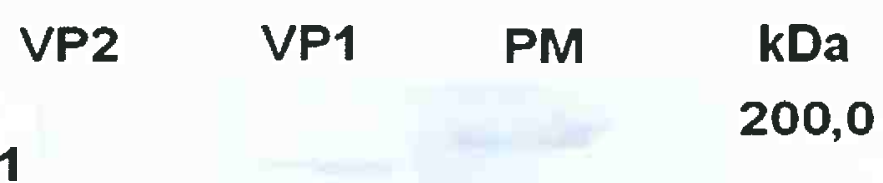

116,2

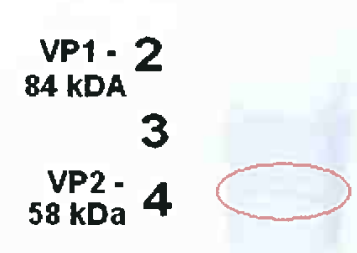

5

6

7
97,4

66,4

45,0

31,0

Figura 37 - "Immunoblotting" dos antígenos recombinantes VP1 e VP2 frente a anticorpos antiB19. 1- PM: miosina (200 kDa), $\beta$-galactosidade $(116,25 \mathrm{kDa})$, fosforilase $\mathrm{B}(97,0$ $\mathrm{kDa})$, soro albumina bovina $(66,2 \mathrm{kDa})$, ovoalbumina $(45 \mathrm{kDa})$, anidrase carbônica (31,0 kDa); inibidor de tripsina (21,5 kDa) e lisosima (14,4 kDa); 2 - antígeno VP1 recombinante $(84,0 \mathrm{kDa}) ; 3$ - antígeno $\mathrm{VP} 2$ recombinante $(58 \mathrm{kDa})$.

Para melhor interpretação dos resultados obtidos no SDS-PAGE foi realizada a determinação do peso molecular relativo das proteínas visualizadas em eletroforese (Material e Métodos, item 3.29) por interpolação (Figura 37). Estes dados confirmam a reação específica dos antigos recombinantes VP1 e VP2 frente a amostra de soro positiva para o vírus $\mathrm{B} 19$. 


\section{DISCUSSÃO}

As leveduras têm sido utilizadas ao longo dos anos como alternativa na expressão de diversas proteínas. Linhagens recombinantes de $S$. cerevisiae têm sido usadas por muito tempo para a produção de valiosas proteínas heterólogas (Macbeth e Bass, 2007). Por serem organismos unicelulares, as leveduras apresentam as mesmas facilidades de manipulação e crescimento que as bactérias, porém com uma série de vantagens adicionais especialmente para a produção de proteínas heterólogas de origem eucarionte e ainda têm a capacidade de excreção eficiente, facilitando a separação dos produtos recombinantes a partir meio de cultura (Valenzuela et al., 1992)

Nas duas últimas décadas a levedura $P$. pastoris, emerge como um sistema altamente popular para a expressão ou expressão e secreção de diversas proteínas recombinantes, (Gurkan e Ellar, 2005; Rahbarizadeh et al., 2006, Solà et al., 2007). A utilização do sistema P. pastoris, composto do promotor $A O X 1$, induzido por metanol, resulta na superexpressão das proteínas recombinantes desejadas. É possível obter-se cerca de 10-100 vezes mais proteínas recombinantes que a expressão no tradicional sistema Saccharomyce cerevisiae (Burrowes et al., 2005). Quando comparado com o sistema bacolovírus, obtem-se cerca de 10 vezes mais proteína recombinante desejada (Craveiro et al., 2006).

Dentro desse contexto, o sistema $P$. pastoris destaca-se, surgindo como uma alternativa promissora para a expressão de proteínas heterólogas, num cenário econômico em que são exigidas maiores quantidades de produtos, em virtude da otimização dos processos indústrias e da competividade desses produtos.

O presente trabalho teve como objetivo principal clonar e expressar na levedura $P$. pastoris os genes codificadores das proteínas estruturais virais do vírus B19, VP1 e VP2, obtendo-se, como produto desse processo, antígenos que fossem capazes de detectar a presença de anticorpos em amostras clínicas de pacientes positivos para vírus B19, empregando-se reações imunoenzimáticas.

$\mathrm{Na}$ construção dos "primers" Pv1, Pv2 e Pr foram delineados parâmetros que permitiram a amplificação por PCR, total dos genes codificadores das proteínas VP1 e VP2 do vírus B19, a partir de soro de paciente com diagnóstico clínico para o vírus B19. Nesta etapa, foi dada atenção para a inserção de caudas com sítios de enzimas de restrição, em ambas as extremidades, adequadas para que o produto amplificado ("amplicon") fosse 
perfeitamente adaptado para inserção no vetor de $P$. pastoris pPIC9K. Ao se desenhar estes "primers", procurou-se alcançar uma relação ótima entre especificidade e eficiência de amplificação, já que estes também são parâmetros que afetariam diretamente a fidelidade da proposta experimental. As estratégicas adotadas nos desenhos dos "primers" mostraram-se satisfatórias para a amplificação dos genes que codificam as proteínas VP1 e VP2 do vírus B19.

Para a realização da clonagem imediata dos "amplicons" obtidos por PCR, optou-se pelo emprego do plasmídio de clonagem pGEM-TEasy (Promega ${ }^{3}$ ), como vetor intermediário (Figuras 9 e 10). Isto justifica-se pela baixa eficiência de clonagem dos produtos de reação da PCR diretamente em vetor final de expressão. De fato, como Mezei et al. (1994), já havia relato, de que o vetor pGEM-TEasy facilitou a clonagem dos produtos da PCR.

Para transformação de $P$. pastoris o plasmídio pPIC9K foi escolhido como vetor de expressão e excreção das proteínas VP1 e VP2, uma vez oferece uma series de vantagens: $O$ promotor $A O X I$ é muito forte, sendo responsável pela transcrição de $90 \%$ das enzimas da célula e é facilmente regulada, característica fundamental para a expressão de proteínas recombinantes (Cereghino et al., 2002; Cós et al., 2006; Solà et al, 2007); permite a expressão e excreção das proteínas recombinantes clonadas; e ainda permite a seleção dos clones recombinantes por complementação gênica (seleção dos transformantes que crescem em meio mínimo sem histidina, $\mathrm{His}^{\dagger}$ ) e posterior seleção dos clones que possuem múltiplas cópias da informação genética desejada, empregando-se a seleção daqueles que são capazes de crescer em altas concentrações de geneticina $(4 \mathrm{mg} / \mathrm{mL})$.(Scorer et al., 1994; Cós et al., 2005)

Somente foram obtidos transformantes de levedura, quando foram empregados entre 8 a $10 \mu \mathrm{g}$ de DNA dos vetores recombinantes linearizados. A necessidade do emprego de grande quantidade de DNA vetor de transformação foi atribuída ao tamanho dos vetores pPICK9-VP1 (11,6 kb) e pPIC9K-VP2 $(10,9 \mathrm{~kb})$; e, ao fato dos transformantes serem resultantes de dois eventos de baixa freqüência: eficiência de transformação, e recombinação homóloga entre o vetor e o alvo presente no cromossomo da levedura. Em experimentos realizados por Hurtado (1997), para obter transformantes de $P$. pastoris, foi necessário o emprego de $2 \mu \mathrm{g}$ de DNA do vetor pPAS1 que tem apenas 7,2 kb.

$O$ processo de transformação empregado resultou na obtenção de clones recombinantes de $P$. pastoris com fenótipo $\mathrm{His}^{+}, \mathrm{Mut}^{+}$, ou seja, com crescimento rápido em meio mínimo contendo metanol como única fonte de carbono. Possivelmente, com múltiplas cópias do cassete de expressão do gene desejado integradas no genoma da levedura. A 
expressão de altos níveis de proteínas recombinantes com transformantes $\mathrm{His}^{+}$, $\mathrm{Mut}^{+}$, como os utilizados neste trabalho, requerem múltiplas cópias do cassete de expressão integradas no genoma de $P$. pastoris (Romanos, 1998; Vassileva et al., 2001; Daly et al., 2005; Pla et al., 2006)

Entretanto, neste trabalho não se buscou a obtenção de clones recombinantes com fenótipo $\mathrm{His}^{+}, \mathrm{Mut}^{\mathrm{s}}$ (crescimento lento em metanol), uma vez que os fragmentos de DNA que codificam VP1 e VP2 (insertos) apresentam sítios para a enzima de restrição $B g l \Pi$, e assim não seria possível a utilização desta enzima para a liberação do fragmento de DNA ladeado pelas extremidades 5' e 3' de $A O X 1$, dos vetores recombinantes (Figura 4A).

Múltiplas integrações do gene $\mathrm{G} 418^{\mathrm{R}}$ no genoma da levedura resultam no aumento da do número de cópias do inserto e, subseqüentemente, resultam no aumento nos níveis de expressão da proteína recombinante desejada (Bisht et al., 2001; Burrowes et al., 2005). Segundo Cos et al. (2005), múltiplas cópias do cassete de expressão integradas no genoma podem proporcionar um crescimento mais rápido, e correspondem a $10 \%$ dos transformantes.

Assim, dentre as colônias de levedura $P$. pastoris GS115 transformadas com pPIC9KVP1 e com pPIC9K-VP2, foram identificadas as que eram capazes de crescer em meio YPD sólido contendo geneticina $\mathrm{G} 418^{\mathrm{R}}$, em concentrações que variavam de 0,5 a $4 \mathrm{mg} / \mathrm{mL}$. Este procedimento visava a seleção dos clones recombinantes que possuíssem entre 7 e 12 cópias do vetor integradas no genoma (Figuras 21 e 22).

Os clones selecionados foram avaliados quanto ao seu crescimento em meio líquido contendo glicerol como principal fonte de carbono. Para tanto, foram construídas curvas de crescimento dos clones recombinantes selecionados. Foram selecionados 3 clones recombinantes obtidos com cada um dos plasmídios. Estes clones por apresentavam colônias maiores do que os demais, nas placas contendo meio YPD com $4 \mathrm{mg} / \mathrm{mL}$ de G418.

Relatos da literatura descrevem que a obtenção de altos níveis de proteínas heterólogas em sistema $P$. pastoris somente é possível com o uso de biorreator. Porém, também, é utilizada a expressão em frascos agitados, com intuito de selecionar os melhores clones recombinantes que expressem as proteínas desejadas para, em etapa subseqüente, serem utilizados na expressão em biorreator (Loewen et al., 1997; Paus, et al., 2002; Masuda et al., 2005; Jin et al., 2006).

A alta densidade celular é um dos pré-requisitos básicos para indução da proteína recombinante desejada (Jungo, 2007b).

A análise dos resultados demonstrados pelo SDS-PAGE (Figura 24) permitiu evidenciar que os clones recombinantes GS115/pPIC9K-VP1 13, GS115/pPIC9K-VP1 19 e 
GS115/pPIC9K-VP2 $2_{10}$, foram capazes de expressar e excretar as proteínas recombinantes VP1 e VP2, e, desta forma, foram selecionados para o prosseguimento dos trabalhos.

Segundo Stratton et al. (1998), em biorreator a expressão de níveis ótimos de proteínas recombinantes são alcançados, quando os valores de concentração celular de $P$. pastoris variam entre $250-400 \mathrm{~g}$ de peso úmido/L (correspondendo a $60-80 \mathrm{~g}$ de peso seco/L e entre 30 e $35 \%$ do volume da cultura) atingidos ao final do processo fermentativo. Os resultados obtidos neste estudo na fermentação em biorreator dos clones produtores das proteínas recombinantes VP1 e VP2 estão de acordo com estes parâmetros.

Com o objetivo de averiguar se os genes que codificam as proteínas estruturais VP1 e VP2 do vírus B19 haviam sido clonados em fase correta de leitura no vetor pPIC9K, foram realizados os sequenciamentos dos genes VP1 e VP2 clonados nos vetores pPIC9K-VP1 e pPIC9K-VP2. Nestes sequenciamentos foram utilizados um conjunto de "primers" (Tabela 4 e Figura 5), que amplificam as regiões internas codificadoras de VP1 e de VP2 de B19, e parte da seqüência sinal do vetor pPIC9K. Esses dados estão apresentados nos Anexos A e B.

Foi feita a tradução eletrônica da seqüência dos nucleotídeos codificadores das proteínas recombinantes VP1 e VP2. Na Tabela 7, estão demonstrados os aminoácidos que apresentam diferenças em relação às seqüências equivalentes de VP1 e VP2 do GenBank. Algumas diferenças, também, já haviam sido observadas em um estudo de sequenciamento do vírus B19 realizado no Brasil por Barbosa, no ano 2004 (depositado no GenBank com número de acesso AY647977). Outros autores como Reis (2003), também, já observaram ligeiras diferenças nas seqüências dos genes que codificam as proteínas VP1 e VP2 do B19, de amostras clínicas, provenientes de estudos do Laboratório de Virologia Clínica Molecular do Instituto de Ciências Biomédicas da Universidade de São Paulo. De fato, o fenômeno desta pequena variação é relatado na revisão de (Heegaard e Brown, 2002). Neste trabalho, além das mudanças sinalizadas na Tabela 7 , foram também observadas mudanças em nucleotídeos que não interferiram em mudanças nos aminoácidos.

A análise da junção das seqüências codificadoras de VP1 e VP2 no vetor pPIC9K (Figuras 17 e 18) permitiu confirmar que as inserções ocorreram em fase correta de leitura, oferecendo as condições necessárias para a expressão e excreção das proteínas recombinantes desejadas pelos clones recombinantes da levedura $P$. pastoris GS115.

A análise da morfologia das células recombinantes antes e após o processo de cultivo no biorreator, não revelou evidências de que haviam sido submetidas a uma condição de estresse. Esta evidência é favorável para a expressão e excreção das proteínas desejadas, pois 
o estresse celular levaria a expressão de produtos indesejáveis no meio de cultura (Paus, et al., 2002).

Segundo Kerr et al. (1996), proteínas recombinantes VP1 e VP2 poderiam ser usadas para detecção de resposta imune contra epitopos lineares de VP1 e VP2 do vírus B19, presente no soro de pacientes.

Os ensaios imunoenzimáticos "Dot-Blot", ELISA e "Western Blot" permitiram evidenciar que os antígenos recombinantes VP1 e VP2 produzidos em sistema $P$. pastoris, foram reconhecidos por anticorpos de soros humanos com histórico positivo para B19 (Figuras 29 a 37). Esses ensaios, também, sugerem que a proteína VP1 recombinante está associada a maiores títulos de anticorpos quando comparada a VP2 recombinante.

Este índice de positividade poderá ser melhorado dinamizando-se e monitorando melhor o processo de expressão no biorreator para a produção dos antígenos. Quanto ao soro testado, uma possível baixa nos valores dos títulos alcançados neste estudo é atribuído ao longo período em que esse soro esteve armazenado a $-20 \mathrm{C}{ }^{\circ}$, que pode ter acarretado em diminuição de reatividade entre $o$ antígeno e anticorpo.

Os índices das reatividades observados nos ensaios imunoenzimáticos com o soro normal frente antígenos recombinantes VP1 e VP2, são bastante bons, uma vez que estão de acordo com o observado por Azzi et al., (2004) ("Antibody response to B19 parvovirus VP1 and VP2 linear epitopes in patients with haemophilic arthritis", utilizando técnicas imunoenzimáticas ELISA e "Western Blot").

A análise dos resultados apresentados na tabelas 10, figuras 36 e 37 evidenciaram a obtenção de proteínas cujos pesos moleculares são correspondentes aos esperados para os antígenos VP1 (84 kDa) e VP2 (58 kDa) (Ozawa et al., 1987; Durigon et al., 1993).

Os antígenos recombinantes VP1 e VP2 de B19 já foram expressos nos sistema $E$. coli; $S$. cerevisiae e bacolovírus. Entretanto, esta é a primeira vez que se relata a expressão destas proteínas em sistema $P$. pastoris.

Segundo Bansal et al. (1992), para que ocorra a indução de anticorpos neutralizantes contra B19 é fundamental o emprego de ambas as proteínas VP1 e VP2. Assim, para a produção de vacina contra B19, será fundamental o emprego de ambas estas proteínas. Neste trabalho foram construidas duas linhagens $P$. pastoris que expressam e secretam VP1 (GS115/pPIC9K-VP1 ${ }_{13,19}$ ) e outras duas linhagem $P$. pastoris que expressam e secretam VP2

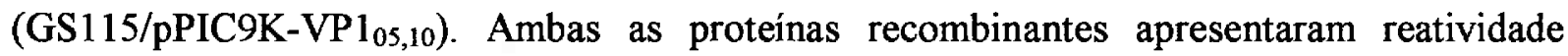
frente anticorpos IgG de pacientes com infecção por B19. 
Cabem neste momento algumas considerações finais que, resumem os principais conceitos e, também, melhor situam este trabalho no contexto de seus objetivos iniciais. Em termos de diagnóstico, os capsídios do parvovirus B19 consiste de duas proteínas estruturais: VP1 (84 kDa, representa 4\%) e VP2 (58 kDa, representa 96\%). O limite de detecção de captura dos antígenos de B19 pela técnica de ELISA é de, aproximadamente, $10^{8}$ partículas/ml. Todavia, dentro de uma perspectiva biotecnológica, as proteinas capsulares (VP1 e/ou VP2) poderiam ser empregadas em testes de ELISA para a detecção de IgM ou IgG específicos contra B19 presentes no soro de pacientes infectados.

De fato, anteriormente a este trabalho, a proteína VP2 já foi expressa em sistema baculovirus e empregada, com sucesso em testes imunoenzimáticos (Brown et al. 1990, 1991). Entretanto, a cultura de células-infectadas com baculovirus de-inseto oferecem as desvantagens de serem facilmente contaminadas, custos elevados e necessidade de pessoal altamente treinado para sua manipulação. Visando um aprimoramento desta proposta, Lowin et al. (2005), construíram uma linhagem recombinante da levedura $S$. cerevisiae que expressa a proteína VP2, intracelularmente. Relatam que os níveis de expressão obtidos em levedura são similares aos alcançados em sistema baculovirus. Entretanto, para a purificação desta VP2 recombinante, são necessários mais que um gradiente de $\mathrm{CsCl}$, visando evitar reações cruzadas com as proteínas de levedura intracelulares (falsos positivos nos testes). Desta forma, os rendimentos finais, obtidos por estes autores, são de apenas $20 \%$ da quantidade total inicial.

Ainda, segundo Bansal et al. (1993), e Lowin et al. (2005), para se obter para uma vacina contra B19 parece ser um pré-requisito ambas as proteínas VP1 e VP2, uma vez que as VLPs formadas com ambas provocariam a indução de anticorpos neutralizantes.

Conforme o exposto acima, entendemos que este trabalho consiste num grande avanço, oferecendo uma proposta consistente muito promissora para o diagnóstico do vírus B19, e abrindo caminhos para uma futura exploração para que a vacina também seja produzida. 


\section{CONCLUSÕES}

Com este estudo, foi possível:

Amplificar, por PCR, os genes que codificam as proteinas VP1 (84 kDa) e VP2 $(58 \mathrm{kDa})$ do vírus $\mathrm{B} 19$, empregando-se os "primers" construídos neste trabalho a partir do DNA viral extraído de soro paciente;

Clonar os fragmentos de DNA correspondentes aos genes que codificam as proteínas VP1 e VP2 do parvovirus humano B19 no vetor intermediário pGEMTEasy, construindo-se os plasmídios pGEM-TEasy-VP1 e pGEM-TEasy-VP2;

Clonar os fragmentos de DNA dos genes que codificam as proteínas VP1 e VP2 do vírus B19, no vetor pPIC9K, obtendo-se os plasmídios pPIC9K-VP1 e pPIC9K-VP2;

$\checkmark$ Construir os clones $P$. pastoris recombinantes que expressam e secretam as proteínas recombinantes VP1 e VP2;

$\checkmark$ Selecionar os melhores clones de $P$. pastoris produtores das proteínas recombinantes desejadas: GS115/pPIC9K-VP1 $1_{13}, \quad$ GS1 15/pPIC9K-VP1 19 , GS115/pPIC9K-VP2 05 , e GS115/pPIC9K-VP2 10 ;

Constatar que as proteínas recombinantes expressas, apresentaram os pesos moleculares esperados: VP1, $84 \mathrm{kDa}$; e VP2, $58 \mathrm{kDa}$;

Utilizar as proteínas recombinantes Vpl e VP2 produzidas neste trabalho em ensaios imunoenzimáticos "Dot-Blot" para identificação de soros de pacientes com infecção por B19;

Utilizar as proteínas recombinantes Vp1 e VP2 produzidas neste trabalho em ensaios imunoenzimáticos ELISA para identificação de soros de pacientes com infecção por B19;

Utilizar as proteínas recombinantes Vp1 e VP2 produzidas neste trabalho em ensaios imunoenzimáticos "Western Blot" para identificação de soros de pacientes com infecção por B19; 


\section{REFERÊNCIAS BIBLIOGRÁFICAS}

Adler SP, Manganello AMA, Koch WC, Hempfling SH, Best M, Risk of human parvovirus B19 infections among school an hospital employees during endemics periods. J Infect Dis., 1993; 168: 361-368.

Anderson MJ, Davis LR, Hodgson J. Occurrence of infection with a parvovirus-like agent in children with sickle-cell anaemia during a two-year period. J Clin Path., 1982; 35: 744-779.

Anderson MJ, Jones SE, Fisher-Hoch SP, Lewis E, Hall SM, Barlett CRL, Cohen BJ, Mortimer PP, Pereira MS, The human parvovirus, cause of erythema infectiosum (fifth disease). Lancet, 1983; 1: 1378.

Anderson MJ, Higgins PG, Davis IR, Willman JS, Jones JSE, Kidd IM, Pattison, RJ, Tyrrell DAJ. Experimental parvovirus infection in humans. J Infect Dis., 1985; 152(2): 257-264.

Anderson LJ, Tsou C, Parker RA, Chorba TIH, Tattersal P, Mortimer PP. Detection of antibodies and antigens of human parvovirus B19 by enzyme-linked immunosorbent assay. J. Clin Microbiol, 1986; 24: 522-526.

Anderson LJ. Role of parvovirus B19 in human disease. Pediatr Infect Dis., 1987; 6: 711-718.

Anderson MJ, Khousan MN, Maxwell DJ, Gould SJ, Happerfiled LC, Smith WJ. Human parvovirus B19 and hydrops fetalis. Lancet, 1988: 1, 535-543.

Anderson MJ, Lewis E, Kidd IM, Hall SM, Cohen BJ. An outbreak of crytcma infectiosun associated with human parvovirus infection. J Hyg., 1993; .9: 85-93.

Anderson IJ, Young NS. Introduction In: Human parvovirus B19 (Monographs in Virol.). Parkes WP, Editor. New York: Karger; 1997. 20: 1-13.

Astell CR. Structure of terminal hairpins and their role in replication of parvovirus genomes. In: Tijssens P, editor. Handbook of parvovirus. Boca Raton: Crc press; 1990. 1: 59-79.

Ausubel RM, Brent R, Kingston RE, Moore DD, Seidman JG, Smith JA, Struhl K. Short Protocols in Molecular Biology. Havard: Med School; 1992. cap. 13.

Azzi A, Manaresi E, Zakrzewska K, Desantis R, Musiani M, Zcrbini M. Antibody response to B19 Parvovirus VP1 and VP2 Linear Epitopes in Patientes with Hacmophilic $\Lambda$ thritis, J Med Virol. 2004; 72: 679-682.

Bansal GP, Hatfield JA, Dunn FE, Warrener P, Yong JF, Top FH, Collett MS, Anderson S, Rosenfeld SJ, Kajigaya S, Young NS. Imunogenicity studies of recombinant human an parvovirus B19. In: Brown li, Chanock RM, Ginsberg HS, Lemer RA, editors. Vaccines. New York: Cold Spring Harbor Laboratory,1992. p.315-319.

Beersma MFC, Claas ECJ, Sopaheluakan T, Krocs $\Lambda$ M. Parvovirus 1319 viral loads in relation to VP1 and VP2 antibody responses in diagnostic blood samples. J Clin Virol. $2005 ; 34: 71-$ 75 . 
Berns KI. Parvoviridae: The viruses and their replications. In Fields BN, Knipe PM, Howley PM; Fundamental Virol. 3 ed. Philadelphia. Raven Press; 1996; p.1017-1041.

Bernuau J, Durand F, Valla D. Parvovirus B19 infection and fulminate hepatitis. Lancet. 1999; v. 353: 754-755.

Bisht H, Chugh DA, SWaminathan S, Khanna N. Expression and purufication of dengue virus type 2 envelope protein as a fusion with hepatitis B surface antigen in P. pastoris. Protein Expression and Purufication. 2001; 23: 84-96.

Boettner M, Prinz B, Holz C, Ulf S, Lang C. High-throughput screening for expression of heterologous proteins in the yeast Pichia pastoris. J of Biotechnol. 2002; 99: 51-62.

Botstein D, Davis RW. Principles and pratice of recombinant DNA research with yeast. In: Strathern JN, Jones EW, Browach JR. The molecular biology of the yeast Saccharomyces cerevisiae - metabolism and gene expression. New York: Cold Spring Harbor Laboratory; 1982; 607-636.

Bradford M M. A Rapid and Sensitive Method for the Quantitation of Microgram Quantities of Protein Utilizing the Principle of Protein-Dye Binding. Anal Biochem. 1976; 72: 248-254.

Brown T, Annd A, Ritchie LD, Clewley JP, Reid TMS. Intrauterine parvovirus infection associate with hydrops fetalis. Lancet, 1984; 2: 1033-1034.

Brown KE, Mori J, Cohen BJ, Field AM. In vitro propagation of parvovirus B19 in primary fetal liver culture. J Gen Virol. 1991; 72: 741-745.

Brown KE, Anderson SM, Young NS. Erythrocyte $\mathrm{P}$ antigen: cellular receptor for B19 parvovirus. Science, 1993; 262: 114-117.

Brown KE, Green SW, Mayolo J $\Lambda$, Bellanti JA, Smith SD, Smith TJ, Young NS. Congenital anemia after transplacental B19 parvovirus infection. Lancet, 1994; 343: 895-896.

Brown Kli, Iluman paryovirus B19 epidemiology and Clin manifestations. In: Parks WP, editor. Human parvovirus B19. New York: Karger, 1997. (Monographs on Virol., 20), 42-55.

Burrowes OJ, Diamond G, Lee TC. Recombinant expression of pleurocidin cDNA using the P. pastoris expression system. J Biomed Biotechnol. 2005; 4: 374-384.

Caul EO, Usher MJ, Burton PA. Intrauterine infection with human parvovirus B19 a light and electron microscopy study. J Med Virol. 1988; 24: 5-66.

Cassinotti P, Siergil G, Michel BA, Bruhlmann P. Presence and significance of human parvovirus B19 DNA in synovial membranes and bone marrow from patients with arthritis of unknown origin. J Med Virol. 1998; 56: 199-204.

Cereghino GPL, Cereghino Л. Heterologous protein expression in the methylotrophic yeast Pichia pastoris. FEMS Microbiol Rev. 2000; 24: 45-66. 
Cereghino GPL, Cereghino JL. Ilgen, C. Cregg, JM. Production of recombinant proteins in fermenter cultures of the yeast Pichia pastoris. Curr Opin Biotechnol. 2002; 13: 329-332.

Chorba T, Coccia P, Holman RC, Tattersali P, Anderson LJ, Sudaman J, Young NS, Kurczynski E, Saarinen UM, Moir R. The role of parvovirus B19 in aplastic crisis and erythema infectiosum (fifth disease). J Infect Dis. 1986; 154: 383-393.

Chyrystie IL, Almeida JD, Welch J. Case report: Electron microscopic detection of human parvovirus B19 in a patient with HIV infection. J Met Virol. 1990; 30: 249-252.

Clewley JP. Detection of human parvovirus using a molecularly cloned probe. J Med Virol. 1985; 15:173-181.

Clewley JP. Polymerase chain reaction assay of parvovirus B19 in clin species. J Clin Microbiol. 1989; 27(12):2647-51.

Cohen BJ, Bucley MM. The prevalence of antibody to human parvovirus B19 in England and Wales. J Med Microbiol. 1988; 25: 151-153.

Cohen BJ, Brown KE. Laboratory infection with human parvovirus B19. J Infect, 1992; 24, 113-114.

Corral DA, Darras FS, Jensen CWB, Ilakala TR, Naides SJ, Krause JR. Parvovirus B 19 infection causing pure red cell aplasia in a recipient of pediatric donor kidneys. Transplantation. 1993; 55: 427-430.

Corcoran A, Mahon BP, Doyle S. B cell memory is directed toward conformational epitopes of parvovirus B19 capsid proteins and the unique region of VP. J Infect Disea. 2004; 189: 1873-1880.

Cossart YE, Field AM, Cant B, Widdows D. Parvovirus-like particles in human sera. Lancet. $1975 ; 72-73$,

Cos O, Serrano A, Montesino JL, Ferrer P, Cregg JM, Valero F. Combined effect of the methanol utilization (Mut) phenotype and gene dosage on recombinant protein production in Pichia pastoris fed-batck cultures. J Biotechnol. 2005; 116: 321-335.

Craveiro RB, Ramalho JD, Chagas JR, Wang PHM, Casarini DE, Pesquero JL, Araújo RC, Pesquero JB. High expression of human carboxypeptidase $\mathrm{m}$ in Pichia pastoris. Purification and partial characterization. Braz J Med Biological Res. 2006; 39: 211-217.

Cregg JM, Vedvick TS, Raschke WC, Recent advances einthe expression of foreign genes in Pichia pastoris. Bio Technol. 1993; 11: 905-910.

Cubel RCN, Scrqucira MM, Santos EO, Pires MF, Cruz CMF, Nascimento JP. Human parvovirus 1319 infections among exanthematic diseases notified as measles. Rev Soc Med Trop Bras. 1997; v. 30: 15-20.

Daly R, Hearn MTW. Review Expression of heterologous proteins in Pichia pastoris: a useful experimental tool in protein engineering and production, $\mathrm{J}$ Mol Recognit. 2005; 18: 119-138. 
Deiss V, Tratschin JD, Weitz M, Siegl G. Cloning of the human parvovirus B19 genome and structuralanalysis of its palindromic termini. Virology. 1990; v. 175: 247-254.

Duncan JR, Carpellini MD, Anderson MJ, Kurtz JB, Anderson MJ, Weatherall DJ. Aplastic crisis due to parvovirus infection in pyruvate kinase deficiency. Lancet. 1983; 14-16.

Durigon EL, Erdman DD, Gary GW, Pallansch MA, Torosk TT, Anderson LJ. Multiple primer pairs for polymerase chain reaction (PCR) amplification of human parvovirus B19 DNA. J Virol Met. 1993; 44: 155-165.

Erdman DD, Durigon EL, Holloway BP. Detection of human parvovirus B19 DNA PCR products by RNA probe hybridization enzyme immunoassay. J Clin Microbiol. 1994; 32(9): 2295-2298.

Erdman DD, Durigon EL, Wang QY, Anderson LJ. Genetic diversity of human parvovirus B19: sequence analysis of the VP1/VP2 Gene from multiple isolates. J Gen Virol. 1996; 77 : 2767-2774.

Erdman DD, Anderson BC, Török TJ, Finkel TH, Anderson LJ. Possible transmission of parvovirus B19 from intravenous immune globulin. J Med Virol. 1997; 53(3): 233-236.

Enders M, Schalasta G, Baisch C, Weidner A, Pukkila J, Kaikkonen J, Hedman J, SöderlundVenermo M, Hedman K. Human parvovirus B19 infection during pregnancy - Value of moderm molecular and serological diagnostics. J Clin Virol. 2006; 35: 400-406.

Finkel TH, Torok TJ, Ferguson PJ, Durigon EL, Zaki SR, Leung DYM, Harbeck RJ, Gelfand EW. Chronic parvovirus B19 infection and systemic necrotizing vasculitis: Opportunistic infection or etiologic agent. Lancet. 1994; 343: 1255-1258.

Freitas RR, Wong D, Boswell F, Miranda MFR, Linhares AC, Shirley J. Desselberger. Prevalence of human parvovirus (B19) and Rubellavirus infections in urban and remote rural areas in northern Brazil. J Med Virol. 1990; 32: 203-208.

Fridell E, Cohen BJ, Wahren B. Evaluation of a synthetic-peptide enzymlinked immunosorbent assay for immunoglobulin $\mathrm{M}$ to human parvovirus B19. J Clin Microbiol. 1991; 29: 1376-1381.

Graeve JLA, Alarcon PA, Naides SJ. Parvovirus BI9 infection in patients receiving cancer chemotherapy: the expanding spectrum of disease. Am J Pediatric Hematol Oncol. 1989; 11: 441-444.

Gillespie SM, Cartter ML, Asch S, Rokos J, Gary W, Tsou C J, Hall DB, Anderson LJ, Hurwits ES. Occupation risk of human parvovirus B19 infection for School and day-care personnel during an outbreak of eruthema infectiosum. J Am Med Assoc. 1990; 263: 20612097.

Gigler A, Dorsch S, Hemauer A, Williams C, Kim S, Young NS, Zolla-Pazner S, Wolf H, Gorny MK, Modrow S. Generation of neutralizing human monoclonal antibodies against parvovirus B19 proteins. J Virol. 1999; 73:1974-1979. 
Guerra OG, Rubio IG, da Silva Filho CG, Bertoni RA, Dos Santos Govea RC, Vicente EJ. A novel system of genetic transformation allows multiple integrations of a desired gene in Saccharomyces cerevisiae chromosomes. J Microbiol Methods. 2006; 67 (3): 437-445.

Gurkan C, Ellar DJ.Recombinant production of bacterial toxins and their derivatives in the methylotrophic yeast Pichia pastoris. Microb Cell Fact. 2005; 4: 33.

Hartner FS, Glieder A, Regulation of methanol utilisation pathway genes in yeasts. Microbial Cell Factories. 2006; 5: 39; 1-21.

Heegaard ED, Brown KE. Human Parvovirus B19. Clin Microbiol Rev. 2002; 15: 3; 485505 .

Hemauer A, von Poblotzki A, Gigler A, Cassinotti P, Siegl G, Wolf H, Modrow SJ. Sequence variability among different parvovirus B19 isolates. Gen Virol. 1996; 77: 1781-1785.

Herrick TP. Erythema infectiosum: Clin report of 74 cases. Am J. Dis. Chid, 1962; 3; 486495.

Hitzemann RJ, Hitzemann BA, Blatt S, Meyerhoff JL, Tortella FC, Kenner JR, Belenky GL, Holaday JW. Repeated electroconvulsive shock: effect on sodium dependency and regional distribution of opioid-binding sites. Mol Pharmacol. 1987; 31(5): 562-566.

Higgins DR, Cregg JM. Introduction to Pichia pastoris. Methods Mol Biol. 1998; 103: 1-15.

Hokynar K, Brunstein J, Soderlung MV, Olli K, Partio EK, Yrjö K, Klaus H. Integrity and full coding sequence of B 19 virus DNA persisting in human synovial tissue. J Gen Virol. 2000; $81 ; 1017-1025$.

Holloway B, Erdman DD, Durigon EL, Murtagh JJ. An exonuclease-amplification coupled capture technique improves detection of PCR product. Nucleic Acids Res. 1993; 21: 39053906.

Houard S, Heinderyckx M, Bollen A. Engineerring of non-conventional yeasts for efficient synthesis of macromolecules: the methylotrophic genera. Biochimie. 2002; 84, 1089-1093

Hurtado CAR. Clonagem e expressão do gene suc2 de Saccharomyces cerevisiae em Pichia pastoris: O seu uso como marcador dominante na transformação gênica desta levedura e avaliação da produção de biomassa a partir de sacarose [Dissertação (Mestrado Interunidade em Biotecnologoia)] São Paulo: Instituto de Ciências Biomédicas - Universidade de São Paulo; 1997.

International Comittee on Taxonomy of Viruses - The Universal Virus Database (ICTVdB): <http://www.ncbi.nlm.nih.gov/ICTVdb/ICTVdB/index.htm>. acessado em : 20/08/2007.

Jin $\mathrm{F}, \mathrm{Xu} \mathrm{X}$, Wang $\mathrm{L}$, Zhang $\mathrm{W}$, Gu D. Expression of recombinant hybrid peptide cecropinA(1-8)-magainin2(1-12) in Pichia pastoris: Purification and characterization; Protein Express Purificat. 2006; 50: 147-156. 
Jungo C, Marinson I, von Stockar U. Mixed feeds of glycerol and methanol can improve the performance of Pichia pastoris cultures: A quantitative study based on concentration gradients in transient continuous cultures. J Biotechnol. 2007a;128: 824-837.

Jungo C, Urfer J, Zocchi A, Marison I, von Stockar U. Optimisation of culture conditions with respect to biotin requirement for the production of recombinant avidin in Pichia pastoris. J Biotechnol. 2007b; 127(4):703-715.

Kerr JR, Coyle PV, Deleys RJ, Patterson CCÍ. Follow-up study of Clin and immunological findings in patients presenting with acute parvovirus B 19; Infection. J. Med. Virol., 1996; v. 48: $68-75$.

Kinney JS, Anderson LJ, Farrar L, Strikas RA, Kumar ML, Kliegman RM, Sever JL, Hurwitz ES, Sikes RK. Risk of adverse outcomes of pregnancy after human parvovirus B19 infection. J lnfect Dis. 1988; 157: 663-667.

Kingsman AJ, Stanway C, Kingsman SM. The expression of homologous and heterologous genes in yeast. Antonie Van Leeuwenhoek. 1987; 53(5): 325-333.

Knisely AS, O'shea PA, Mcmillan P, Singer DB, Magid MS. Electron microscopic identification of parvovirus virions in erythroid-line cells in fatal hidrops fetalis, Pediatr Pathol. 1988; 8(2):163-170.

Knott PD, Welply YGA, Anderson MJ. Serological proved intrauterine infection with parvovirus. Br Med J. 1984; v.289: 1660.

Kobayashi K. Summary of recombinant human serum albumin development, Biologicals. $2006 ; 34: 55-59$.

Kukuruzinka MA, Bergh MLE, Jackson BJ, Protein glycosylation in yeast. Ann Rev Biochem. 1987; 56: 915-944.

Langnas AM, Markin RS, Cattral MS, Naides SJ. Parvovirus B 19 as a possible causative agent of fulminant liver failure and associated aplastic anemia. Hepatology. 1995; 22: 16611665 .

Laemmli UK. Cleavage of structural proteins during the assembly of the head of bacteriophage T4, Nature. 1970; 227(259): 680-5.

Lisboa, CP. Detecção do parvovirus humano B19 em doadores de sangue, utilizando a reação de polimerização em cadeia (PCR). [Dissertação (Mestrado Microbilogia)]. São Paulo : Instituto de Ciências Biomédicas - Universidade de São Paulo; 1997.

Listernick R, Parvovirus infections in childhood. Pediatr Dermatol. 1986; 3: 435438.

Loewen MC, Lui X, Davies PL, Daugulis AJ. Biosynthetic production of type II fish antifreeze protein fermentation by Pichia pastoris, Appl Microbiol Biotechnol. 1997; 48: 480486. 
Lowden E, Weinstein L. Unexpected second trimester pregnanancy loss due to maternal parvovirus B19 infection. South Med J. 1997; 90: 702-704.

Lowin T, Raab U, Schroeder J, Franssila R, Modrow S. Parvovirus B19 VP2-Proteins Produced in Saccharomyces cerevisiae: Comparison with VP2-Particles Produced by Baculovirus-Derived Vectors. J Veter Medic. 2005; 52: 348-352.

Luo W, Astell CR.A novel protein encoded by small RNAs of parvovirus B19. Virol.. 1993;195(2): 448-455.

Macauley-Patrick S, Fazenda ML, McNeil B, Harvey M. Heterologous protein production using the Pichia pastoris expression system. Yeast. 2005; 22: 249-270.

Macbeth MR, Bass BL. Large-scale overexpression and purification of ADARs from Saccharomyces cerevisiae for biophysical and biochemical studies. Methods Enzymol. 2007; 424: 319-331.

Masuda T, Ueno Y, Kitabatake N. High yield secretion of the sweet-tasting protein lysozyme from the yeast Pichia pastoris. Protein Express Purificat. 2005; 39: 35-42.

Makrides C. Strategies for achieving high-level expression of genes in Escherichia coli. Microbiol. Mol Biol. 1996; 60: 511-538.

Mezei LM, Storts DR. Purification of PCR products. In: Griffin HG, Griffin AM. PCR Technology: Current Innovations. CRC Press editors. 1994, Boca Raton, FL, 21.

Miyamoto NG, Moncollin V, Egly JM, Chambon P.Specific interaction between a transcription factor and the upstream element of the adenovirus- 2 major late promoter. EMBO J. 1985; 4: 3563-3570.

Morey AL, Niolini U, Welch CR, Economides D, Chanberlain PF, Cohen BJ. Parvovirus B19 infection and transient fetal hydrops. Lancet. 1991; 337: 496.

Mortimer PP, Luban NLC, Kelleher JF, Cohen BJ. Transmission of serum parvovirus-like virus by clotting-factor concentrates. Lancet. 1983;2: 482-484.

Munshi NC, Zhou S, Woody MJ, Morgan DA, Srivastava A. Successful replication of parvovirus B19 in the human megakaryocytic leukemia cell line MB-02. J Virol. 1993; 67: $562-566$.

Nascimento JP, Buckley M, Brown K, Cohen BJ. The prevalence of antibodie to human parvovirus B19 in Rio de Janeiro, Brazil. Rev Inst Med Trop S P. 1990; 32: 41-45.

Nicle EAMW, Krocs ACM. Human parvovirus B19: relevance in internal medicine. Neth J Med. 1999; 54: 111-130.

Nonoue T, Okochi K, Mortimer PP, Cohen BJ. Human parvovirus BI9 and erythema infectiosum. J Pediatr. 1985; 107: 38-40.

Odibo AO, Campbell WA, Felbman D, Leo MV, Borgida AF, Rodis SJF. Resolution of 
human parvovirus B19 induced nonimune hydrops after intrauterine transfusion. 1998; 17:547-550.

Oliveira MI. Infecção pelo Parvovirus B19 em crianças, adolescentes e adultos com diagnóstico clínico de sarampo ou rubéola [dissertação (Mestrado em Microbiologia)]. São Paulo: Instituto de Ciências Biomédicas da Universidade de São Paulo; 1998.

Ozawa K, Kurtzman G, Young N, Replication of the B19 parvovirus in human bone marrow cell cultures. Science. 1986; 233: 883-886.

Ozawa AK, Ayub J, Yu-shu H, Kurtzman G, Shimada T, Young N. Novel transcription map for the B 19 (human) pathogenic parvovirus. J Virol. 1987; 2395-2406.

Palmer P, Pallier C, Leruez-Ville M, Deplanche M, Morinet F. Antibody response to human parvovirus B19 in patients with primary infection by immunoblot assay with recombinant proteins. Clin Diagnostic Laboratory Immunol. 1996; 3(2): 236-248.

Pattison JR, Jones SE, Hodgson J, Davis LR, White JM, Stroud CE, Murtaza L. Parvovirus infections and hypoplastic crisis sickle-cell anemia. Lancet. 1981; 1: 664-665.

Paus EJ, Willey J, Ridge RJ, Legg CR, Finkelman MA, Novitsky TJ, Ketchum PA. Production of recombinant endotoxin neutralizing protein in Pichia pastoris and methods for its purification; Protein Express Purificat. 2002; 26: 202-210.

Pla IA, Damasceno LM, Vannelli T, Ritter G, Batt CA, Shuler ML. Evaluation of $\mathrm{Mut}^{+}$and Mut ${ }^{s}$ Pichia pastoris phenotypes for high level extracellular scFV expression under feedback control of the methanol concentration. Biotechnol Prog. 2006; 22, 881-888.

Pillay D, Patou G, Hurt S, Kibbler CC, Griffiths PD. Parvovirus B19 outbreak in a children's ward. Lancet. 1992; 339: 107-9.

Pinho JRR, Alves FAF, Vieira FA, Moralez SMS, Fonseca PEL, Guz B, Wakamatsul A, Cançado ELR, Carrilho FJ, Da Silva LC, Bernardini AP, Durigon EL. Detection of human parvovirus B 19 in a patient with hepatitis. Bras J Med Biol Res. 2001; 34: 1131-1138.

Plummer FA, Hammond GW, Forward K. An erythema infectiosumlike illneess caused by human parvovirus infection. N Engl J Med. 1985; 313, 74-79.

Public Health Laboratory Service Working Party on Fifth Disease. Prospective study of human parvovirus (B19) infection in pregnancy, 1990; 300, 1166-1170.

Rahbarizadeh F, Rasaee MJ, Forouzandeh M, Allameh AA. Over expression of anti-MUC1 single-domain antibody fragments in the yeast Pichia pastoris. Mol Immunolog. 2006; 43(5): $426-435$.

Rayment FB, Crosdale E, Morris DJ, Pattison JR, Talbot P, Clare JJ. The Production of human capisid proteins in Escherichia coli and their potential as diagnostic antigens. $\mathbf{J}$ Gen Virol. 1990; 71: 2665-2672.

Reid DM, REID TMS, Browns T, Rennie JAN, Eastmond CJ. Human parvovirus associated 
arthritis: a Clinical and laboratory description. Lancet. 1985; 71: 422-425.

Reis H. Expressão das proteínas VP1 e VP2 do parvovírus humano B19 para produção de Kit diagnóstico. [Dissertação (Mestrado Interunidade em Biotecnologia)]. São Paulo - Instituo de Ciências Biomédicas - Universidade de São Paulo; 2003.

Romanos M, Scorer C, Sreekrishna K, Clare J. The generation of multicopy recombinant strains. Methods Mol Biol. 1998; 103: 55-72.

Romanos MA, Makoff AJ, Fairweather NF, Clare JJ, Slater DE, Beesley KM, Rayment, FB, Payne MM. Expression of tetanus toxin fragment $\mathrm{C}$ in yeast: gene synthesis is requerid to eliminate fortuitous polyadenylation sites in AT-rich DNA. Nucleic Acids Res. 1991; 19: 1461-1467.

Romanos MA, Scorer CA, Clare JJ. Foreign gene expression in yeast: a review. Yeast. 1992; $8 ; 423-488$.

Rosenfeld SJ, Yosiumoto K, Kajigaya S, Anderson S, Young NS, Held A, Warrener, P, Bansal G, Collet MS. Unique region of the minor capsid protein of human parvovirus B19 is exposed on the virion surface. J Clin Invest. 1992; 89: 2023-2029.

Saikawa T, Anderson S, Momoeda M, Kajigaya S, Young NS. Neutralizing linear epitopes of B19 parvovirus cluster in the VP1 unique and VP1-VP2 junction regions. J Virol. 1993; 67(6): 3004-3009.

Sambrook J, Russel DW. Molecular cloning: a laboratory manual. New York: Cold spring Harbor Laboratory Press; 2001.

Serjeant GR, Manson K, Topley JM. Outbreak of aplastic crises in sickle cell anaemia associated with parvovirus-like agent. Lancet. 1981; 2: 595-597.

Serke S, Schwarz TZ, Baurmann H, Kirsch A, Hottentrager B, Von Brunn A, Roggendorf M, Huhn D, Deinhardu F. Productive infection of in vitro generated haemopoietic progenitor cells from normal human adult jperipheral blood with parvovirus B19: studies by morphology, immunocytochemistry, flow cytometry and DNA-hybridization $\mathrm{Br} J$ Haematol. 1991, 79: 6-13.

Shade RO, Blundell MC, Cotmore SF, Tattersall P, Astell CR. Nucleotide sequence and genome organization of human parvovirus B19 isolated from the serum of a child during aplastic crisis. J of Virol. 1986; 58(3): 921-936.

Shuster JR, Moyer D, Irvine B. Sequence of the Kluyveromyces lactis URA3 gene. Nucleic Acids Res. 1987; 15(20): 8573.

Siegl G, Bates RC, Berns KI, Carter BJ, Kelly DC, Kurstak E, Tattersall P. Characteristics and taxonomy of Parvoviridae. Intervirology. 1985; 23: 61-73.

Smoleniec JS, Pillai M. Management of fetal hydrops associated with parvovirus B19 infection. British J Obstetrics Gynaecol.1994; 101(12):1079-81. 
Soderlund M, von Essen R, Haapasaari J, Kiistala U, Kiviluoto O, Hedman K. Persistence of parvovirus B19 DNA in synovial membranes of young patients with and without chronic arthropathy. Lancet. $1997 ; 349 ; 1063-1065$.

Solà A, Jouhten P, Maaheimo H, Sànchez-Ferrando F, Szyperski T, Ferrer P. Metabolic flux profiling of Pichia pastoris grown on glycerol/methanol mixtures in chemostat cultures at low and high dilution rates, Microbilogy. 2007; 153: 281-290.

Srivastava $\mathrm{CH}$, Zhou S, Munshi NC, Srivastava A Parvovirus B19 replication in human umbilical cord blood cells. Virol. 1992;189(2): 456-461.

Stoll T, Bruhlmann P, Brunner U, Treier A, Cassinotti P, Michel BA. Parvovirus B19 induced arthritis/arthropathy--an important differential diagnosis of chronic polyarthritis, Schweiz Med Wochenschr. 1995; 125: 347-354.

Straton J, Chiruvolu V, Maeagher M. High Cell-Density Fermentation in Methods in Molecular Biology (Higgins DR, Cregg JM, eds.) Humana Press, Totowa, NJ. (1998), p. 107-120.

Sventina M, Krasevec N, Gaberc-porekar V, Komel R. Expression of catalytic subunit of bovine enterokinnase in the filamentous fungus Aspergillus niger. J Biotechnol. 2000; 76: 245-251.

Torok TJ, Human parvovirus B19; In: Remington Js, Klein J. O. (eds): Infectious Diseases of the fetus and Newborn Infant, 4.ed. Philadelphia: Saunders, 1995, 668-702.

Towbin $\mathrm{H}$, Gordon J. Eletrophoretic transfer of proteins from polyacrilamide gels to nitrocellulose sheets: procedure and some applications. Proc Natl Acad Sci. 1979; 76: 43504354.

Towler DA, Adams SP, Eubanks SR, Towery DS, Jackson-Machelski E, Glaser L, Gordon JI. Myristoyl CoA:protein N-myristoyltransferase activities from rat liver and yeast possess overlapping yet distinct peptide substrate specificities. J Biol Chem. 1988; 263:1784-1790.

Tzang BS, Tsay GJ, Lee Y, Li C, Sun Y, Hsu T. The association of VP1 unique region protein in acute parvovirus B19 infection and anti-phospholipid antibody production. Clin Chim Acta. 2007a; 378: 59-65.

Tzang BS, Lee YJ, Yang TP, Tsay GJ, Shi JY, Tsai CC, Hsu TC. Induction of antiphospholipid antibodies and antiphospholipid syndrome-like autoimmunity in naive mice with antibody against human parvovirus B19 VP1 unique region protein. Clin Chim Acta. 2007b; 382: 31-36.

Uike N, Miyamura T, Obama L, Takahira H, Sato H, Kozuru M. Parvovirus B19 - associated haemophagocytosis in Evans syndrome: aplastic crisis accompanied by severe thrombocytopenia. Br J Haematol. 1993; 84, 530-532.

U.S.D.A. Agricultural Statistics. New York; G.P.O., 1976. 
Valenzuela P, Medina A, Rutter WJ, Ammerer G, Hall BD. Synthesis and assembly of hepatitis B virus surface antigen particles in yeast. Nature. 1982; 298:347-350.

Vassileva A, Chugh DA, Swaminathan S, Khanna N. Expression of hepatitis B surface antigen in the methylotrophic yeast Pichia pastoris using the GAP promoter. J Biotechnol. 2001; 88: 21-35.

Vicari, D. Padronização da técnica semi-nested-PCR em tubo único para deteç̧ão do vírus B19. 72 f. [Dissertação (Mestrado Interunidade em Biotecnologia)]. São Paulo: Instituto de Ciências Biomédicas - Universidade de São Paulo; 2002.

Weiland HT, Salimans MMM, Fibbe WE, Kluin PM, Cohen BJ. Prolonged parvovirus B19 infection with severe anaemia in bone marrow transplant recipient. $\mathrm{Br} \mathrm{J}$ Haematol. 1989; 71 : 300 .

Yaegashi N, Shiraishi H, Takeshita T, Nakamura M, Yajima A, Sugamura K. Propagation of human parvovirus B19 in primary culture of erythroid lineage cells derived from fetal liver. J Virol. 1989; 63: 2422-2426.

Yaegashi N, Okamura K, Yajima A, Murai C, Sugamura K. The frequency of human parvovirus B19 infection in nonimmune hydrops fetalis. J Perinat Med. 1994; 22: 159-163.

Yoshida M, Tezuka TO. Conjunctivitis caused by human parvovirus B19 infection. Ophthalmologica. 1994; 208: 161-172.

Yoto Y, Kudoh T, Haseyama K, Suzuki N, Chiba S. Human parvovirus B19 infection associated with acute hepatitis. Lancet. 1996; 347: 1563-1574.

Young NS. Hemalologic and hematopoietic consequences of B19 parvovirus infection. Semin Hemat. 1988; 25: 159-172.

Young NS. B19 parvovirus. Baillieres Clin Haematol. 1995; 8(1): 25-56. 
ANEXOS 


\section{$\operatorname{Anexo} \mathbf{A}$}

Análise do sequenciamento do gene que codifica a proteína VP1 (2345 nt), clonada no plasmídio pPIC9K-VP1: alinhamento com a sequeência do vírus B19 (Ref. M13178, Shade et al., 1986) GenBank.

RTGAGTAAMARAGTGGCAMTGGTGGGAAGTGATGATAAATTTECTAAAGCTGTGTATCAGCARTITGTGGARTITIA

$\begin{array}{llllllll}10 & 20 & 30 & 40 & 50 & 60 & 70 & 80\end{array}$

seq. GenBank vP1 ATGAGTAAAAAA GTGGCAAATGGTGGAAAGTGATGATAAATTTGCTAAAGCTGTGTATCAGCAATTTGTGAATTTTA 60 Consenso VP1 ATGAGTAAAAAAAGTGGCAATGGTGGGAAGTGATGATMAATTTGCTAABGCTGTGTATCAGCAATTTGTGGATTTTA 80

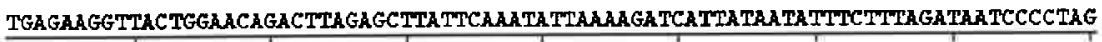

$\begin{array}{llllllll}90 & 100 & 110 & 120 & 130 & 140 & 150 & 160\end{array}$

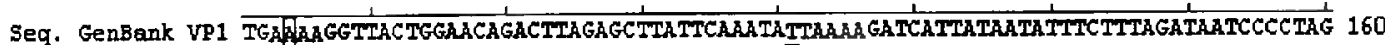

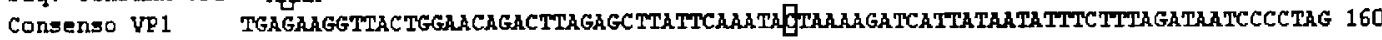

AAAACCCATCCTCTCTETTPGACTTAGTTGCTCGTATTAAAAATACCTTAAAAATTCTCCAGACTTATATAGTCATCAT

$\begin{array}{llllllll}170 & 180 & 190 & 200 & 210 & 220 & 230 & 240\end{array}$

Seq. GenBank VP1 AAAACCCATCCTCTCTGTTTGACTTAGTTECTCETKTTAAAAA TAACCTTAAAAACTCTCCAGACTTATATAGTCATCAT 240 Consenso VP1 AhaCCCATCCTCTCTGTTTGACTTAGTTGCTCGTATThAARATACCTTAAAARTICTCCAGACTPATATAGTCATCAT 240

ITTCAAGTCATGGACAGTTATCTGACCACCCCCATGCCTIATCATCCAGTAGCAGTCATGCAGAACCTAGAGGAGAARA

$\begin{array}{lllllll}250 & 260 & 270 & 280 & 290 & 300 & 310\end{array}$

seq. GenBank vp1 TITCAAAGTCATGGACAGTTATCTGACCACCCCCATGCCTTATCATCCAGTAGCAGTCATGCAGAACCTAGAGGAGAAA 320 Consenso VP1 TTTCAAAGTCATGGACAGTTATCTGACCACCCCCATGCCTTATCATCCAGTAGCAGTCATGCAGAACCTAGAGGAGAAAA 320

TGCAGTATTATCTAGTGAGGCTLCACAAGCTGGGCAATTAGCGTACAACTACCCGGTACTAACTATGTTGGGCCTG

$\begin{array}{lllllll}330 & 340 & 350 & 360 & 370 & 380 & 390\end{array}$

Seq. GenBank vet TGCAGTATIATCTAGTGAGACTTACACMACCTGGGCAGTTAGCGTACAACTACCCGGTACTARTATGTTGGGCCTE 400 Consenso VP1 TGCAGTATIATC TAGTGAaGACTTACACAAGCCTGGGCAGTLGCGTACAACTACCCGGACTAACTATGTTGGGCTG 400

GCAATGAGCTACAAGCTGGGCCCCCGCAAAGTGCTGTTGACAGTGCTGCAAGGATTCATGACTITAGGTATAGCCAACTG

$\begin{array}{lllllll}410 & 420 & 430 & 440 & 450 & 460 & 470\end{array}$

Seq. GenBank Vq1 GCAATGAGCTACAAGCTGGGCCCCGCARATGCTGTTGACAGTGCTGCARGGATTCATGACTTTAGGTATAGCCRACTG 480 Consenso VP1 GCAATGAGCTACARGCTGGGCCCCCGCAAATGCTGTTGACAGTGCTGCAAGGATCATGACTTTAGGTATAGCCAACTG 48D

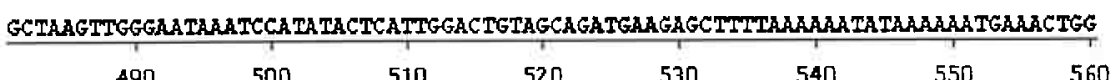

$\begin{array}{lllllll}490 & 500 & 510 & 520 & 530 & 540 & 550\end{array}$

Seq. GenBank VP1 GCTAAGTTGGGATAAATCATATACTCATTGGACTGTAGCAGATGAAGAGCTHTTAMAAMA TATAAAAAATGAAACTGG 560 Consenso VP1 GCTAAGTTGGGAATAAATCCATATACTCATTGGACTGTAGCAGATGAAGAGCTTTTAAAAAA TATAAAAAATGAACTGG 560

GTTTCAAGCACAAGTAGTAAAAGA CTACTTTACTTTAAAAGGTECAGCTGCCCCTGTEGCCCATHTICA,

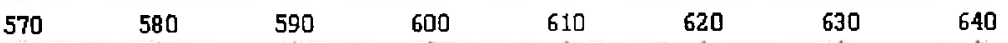

Seq. GenBank vP1 GTITCAAGCACAAGTAGTAAAGACTACITIACTTTAAAGGTGCAGCTGCCCCTGTGGCCCATTTCAAGGAGTTTGC 640

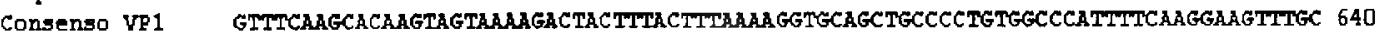

CGGAGTTCCCECTLACAACGCCTCAGAAAAATACCCAAGCATGACTICAGTTAATTCTGCAGAGGCAGCACTGGTGCA

$\begin{array}{llllllll}650 & 660 & 670 & 680 & 690 & 700 & 710 & 720\end{array}$

seq. GenBank vP1 CGGAAGTTCCCGCTTACAACGCCTCAGAAAAMTACCCAAGCATGACTTCAGTTAATTCTGCAGAAGCCAGCACTGGTGCA 720 Consenso V1 1 CGGAAGTTCCGCTTACACGCCTCAGAAAARTACCCAAGCATGACTTCAGTTAATTCTGCAGAAGCCAGCACTGGTGCA 720

GGAGGGGGGGCAGTAATTCTGTCAAAGCATGTGGAGTGAGGGGCCACTTTTAGTGCTACTCTGLACTTGLACATT

$\begin{array}{llllllll}730 & 740 & 750 & 760 & 770 & 780 & 790 & 800\end{array}$

Seq. GenBank VP1 GGAGGGGGGGCAGTAATTCTGTCARABGCATGTGGAGTGAGGGGGCCACTTTTAGTGCTAACTCTGTAACTTGTACATT 80D Consenso VP1 GGAGGGGGGGCAGTAATDCTGTCAAAAGCATGTEGAGTGAGGGGCCACTTTTAGTECGAACTCTGTAACTTGTACATT 8DD

Majority TTCCAGACAGTTHTTAATTCCATATGACCCAGAGCACCATTATAAGGTGTTTTCTCCCGCAGCGAGTAGCTGCCACAATG

$\begin{array}{llllllll}810 & 820 & 830 & 840 & 850 & 860 & 870 & 880\end{array}$

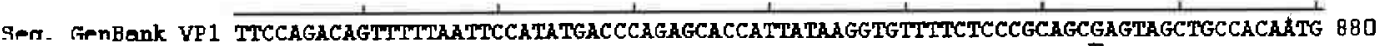

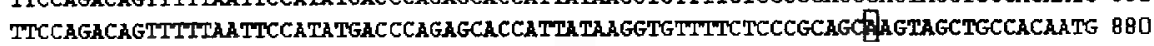


CCAGTGGAAGGAGGCAAAGGTTECACCATTAGTCCCATAATGGGATACTCAACCCCATGGAGATATTTAGATTTTAAT

$\begin{array}{lllllll}890 & 900 & 910 & 920 & 930 & 940 & 950\end{array}$

Seq. GenBank VP1 CCAGTGGAAAGGGGCAAAGGTTTGCACCATGAGTCCCATAATGGGATACTCAACCCCATGGAGATATTTAGATTTAAT 960 Consenso VP1 CCAGTGGAAAGAGGCAAGGTITECACCATTAGTCCCATAATGGGTACTCAACCCATGGAGATATITAGATTTTAR 960

GCTTIAAATTIATTHTTTTCACCTITAGAGTTTCAGCACTTAATTGAAAATTATGGAAGTATAGCTCCTGATECITTARC

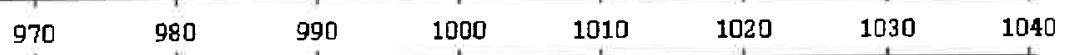

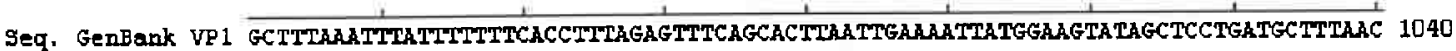
Congengo VP1 GCTTTAAATTTATTTTTTCACCTTTAGAGTTTCAGCACTTAATTGAAAATATGGAAGTATAGCTCCTGATECTTTAAC 104D

TGTAACCATATCAGAAATTCTGTTAAGATGTTACAGACAAAACTGGAGGGGGGGTACAGGTLACTGACAGCACTACAG

\begin{tabular}{|c|c|c|c|c|c|}
\hline .050 & 1060 & 1070 & 1080 & 1090 & 1100 \\
\hline
\end{tabular}

Seq. GenBenk VP1 TGTAACCATATTAGAAATGCTGTTAAGGATGTTACAGACAAAACTGGAGGGGGGGTACAGGTTACTGACAGCACTACAG 1120 Consenso VP1 TGTAACCATATCAGAATTGCTGTTAAGGATTTACAGACAAAACTGGAGGGGGGTACAGGTTACTGACAGCACTACAG 1120

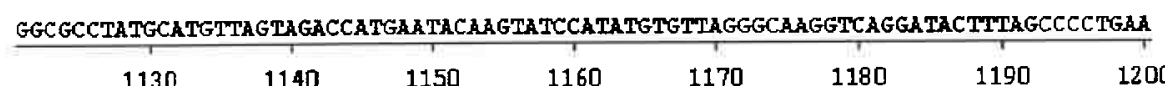

$\begin{array}{lllllll}1130 & 1140 & 1150 & 1160 & 1170 & 1180 & 1190\end{array}$

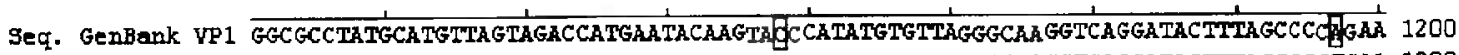
Consenso VP1 GGCGCCTATGCATGTTAGTAGACCATGAATACAAGTATCCATATGTGTTAGGGCAAGGTCAGGATACITTAGCCCCTGAA 1200

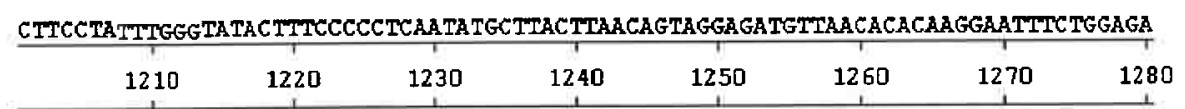

seq. GenBank vp1 CTTCCTATITGGGTATACTITCCCCCTCAATATGCTTACTIAACAGTAGGAGATGTTAACACACAAGGAATTCTGGAGA 1280 Consenso VP1 CTTCCTATTTGGGTARCTTCCCCCTCAATATGCTTACTTAACAGTAGGAGATGTAACACACAAGGATTHCTGGAGA 1280

CAGCAMMAA TTAGCAGTGAGAATCAGCATTITATGTTTTGGACACAGTTCTITICAGCTTTTAGGTACAGGAGGTR

$\begin{array}{llllllll}1290 & 1300 & 1310 & 1320 & 1330 & 1340 & 1350 & 1360\end{array}$

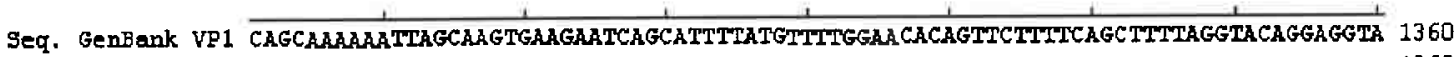
Consenso VP1 CAGCAABAAATTAGCAAGTGAAGATCAGCATTTTATGTTITGGAACACAGTTCTITTCAGCTTTAGGTACAGGAGGTA 1360

GAGCATCTATGTCTTATAAGTTCCTCCAGTGCCCCCAGAAAATTAGAGGGCTGTAGTCAACACTTTTATGAAATGTAC

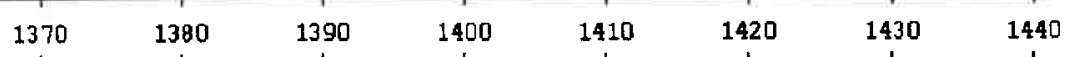

seq. GenBank vp1 CAGCATCTATGTCTTATAAGTTTCCTCCAGTGCCCCCAGAAAATTTAGAGGCTGGaGTCAACACTITTATGAAATGTAC 1440 consenso VP1 CAGCA 1 CTATGTCITAGAaGTTCCTCCAGTECCCCCAGAAAATITAGAGGGCTGTAGTCAACACTTMTATGAATGTAC 1440

AaTCCCTTATACGGATCCCGCTHAGGGGTTCCTGACACATIAGGAGGTGACCCAAAATTTAGATCTTTAACACATGAAGA

$\begin{array}{llllllll}1450 & 1460 & 1470 & 1480 & 1490 & 1500 & 1510 & 1520\end{array}$

Seq. GenBank VP1 AATCCCTIATACGGATCCGCITAGGGGTTCTGACACATTAGGAGTGACCCAAAATTAGATCTTTAACACATGAAGA 1520 Consenso VP1 AATCCTIATACGGATCCCGCTTAGGGGTTCTGACACATTAGGAGGGACCCAAAATTAGATCTTTAACACATGAGG 1520

CCATGCAATCAGCCCCARAACTICATECCAGGECCACTAGTAAACTCAGTGTYTACAAGGGAGGGAGACAGCTCTAMTA

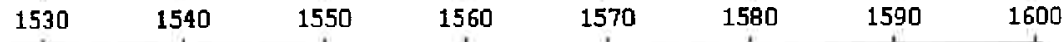

Seq. GenBank vP1 CCATGCAATTCAGCCCCAAAACTTCATGCCAGGGCCACTAGTAAACTCAGTGTCTACAAAGGAGGGAGACAGCTCTAATA 1 1600 Consenso VP1 CCATGCAATCAGCCCCAAAACTCATGCCAGGGCCACTAGTAAACTCAGTGTCTACAAGGAGGGAGACAGCTCTART 1600

CTGGAGCTGGAAMACCTTAACAGGCCTTAGCACAGGTACCTCTCAARACACTAGAATATCCTTACGCCCTGGGCCAGTG

$\begin{array}{llllllll}1610 & 1620 & 1630 & 1640 & 1650 & 1660 & 1670 & 1680\end{array}$

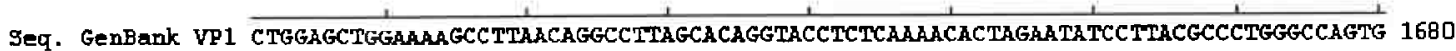
Consenso VP1 CTGGAGCTGGAAAGCCTTAACAGGCCTTAGCACAGGTACCTCTCAAAACACTAGAATATCCTTACGCCCTGGGCCAGTG 1680

TCTCAGCCATACCACCACTGGGACACAGATAATATETCACAGGATAA,TGCCATHCTCATGGTCAGACCACTLATG

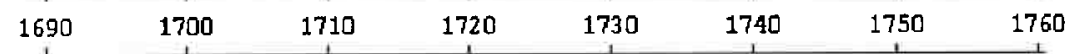

Seq. GenBenk vP1 TETCAGCCATACCACCACTGGGACACAGATAAATATGTCACAGGAATAAATGCCATTTCTCATGGTCAGACCACTTATGG 1760 Consenso VP1 TCTCAGCCATACCACCACTGGGACACAGATAA TATGTCACAGGATMAATGCCATTTCTCATGGTCAGACCACTTATGG 1760 
TAACGCTGAAGACAARGATATCAGCAAGGAGTGGGTAGATTCCAAATGAAAAGAACAGCTAAAACAGTIACAEGGTT

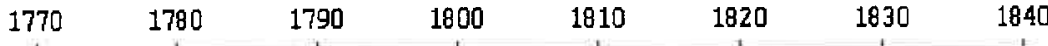

Seq. GenBank YP1 TARCGCTGARGACAAAGAGTATCAGCAAGGAGTGGGTAGATTTCAARTGABAAR GARCAGCTAAMACAGTTRCAGGGTT 1840 Consenso VP1 TARCGTGAAGACAAAGATATCAGCARGGGTGGTAGATTTCCAAATGAAAAGAACAGCTAAAACAGTTACAGGGTT 1840

TARACATGCACACCTACTTMCCCAATAAAGGAACCCAGCARTATACAGACAATTGAGCGCCCCCTAATGGTGGGTTCT

$\begin{array}{llllllll}1850 & 1860 & 1870 & 1880 & 1890 & 1900 & 1910 & 1920\end{array}$

Seq. GenBank IP1 TAAACATGCACACCTACTTTCCCATTAAGGACCCAGCAATATACAGATCAAATGAGCGCCCCCTAATGGTGGGTTET 1920 Consenso VP1 TAAACATGCACACCTACTTCCCAATAABGGACCCAGCAATATACAGATCAAATTGAGCGCCCCCTAATGGTGGTTLT 1920

GTATGGAACAGAAGAGCCCTCACTATGAAAGCCAGCTGTGGAGTAAAATTCCAAATTLAGATGACAGTTITAAACTCA

$\begin{array}{lllllll}1930 & 1940 & 1950 & 1960 & 1970 & 1980 & 1990\end{array}$

Seq. GenBank VP1 GTATGGAACAGAAGAGCCTTCACTATGAAAGCCAGCTGTGGAGTAAAATTCCAAATTTAGATGACAGTITTAAAACTCA 2000 Consenso VP1 GTATGGACAGARGACCCTTCACTATGAAAGCCAGCTGTGGAGAAAATTCAATTIAGATGACATTITAAACTCR 2000

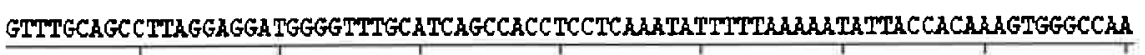

$\begin{array}{lllllll}2010 & 2020 & 2030 & 2040 & 2050 & 2060 & 2070\end{array}$

Seq. GenBank VP1 GTTGCAGCCTTAGGAGGTGGGGTTGCATCAGCCACCTCCTCAMTATITITAAAARTATACCACAAAGTEGGCCAA 2080

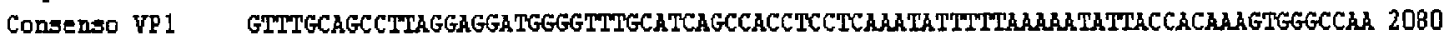

TTGGAGGTA TIAA TCAA TGGGARTACTACCTTAGTTCAGTATGCCGTGGGAATTATGACAGTAACTATGACATTTAAA

$\begin{array}{lllllll}2090 & 2100 & 2110 & 2120 & 2130 & 2140 & 2150\end{array}$

Seq. GenBank vP1 TTGGAGGTA TIAAATCAATGGGAATTACTACCTTAGTTCAGTATGCCGTGGGARTTATGACAGTAACTATGACATTAAA 2160 Consenso VP1 TTGGAGGTATTAAA TCAATGGGARTACTACCTTAGTCAGTATGCCGTGGGARTRTGACAGTAACTATGACATTTAA 2160

TTGGGGCCCCGTAABGCTACGGGACGGTGGARTCTCAACCTGGAGTATATECCCCGCACGCAGCAGGTCATITACCATA

$\begin{array}{lllllll}2170 & 2180 & 2190 & 2200 & 2210 & 2220 & 2230\end{array}$

Seq. GenBank VP1 TIGGGGCCCCGTAMGCTACGGGACGGTGGAATCTCAACCTGGAGTATATCCCCCGCACGCAGCAGGTCATTTACCATA 2240 Consenso VP1 TTGGGGCCCGTAAAGCTA C)GGACGGTGGAATCCTCAACCGGGAGTATATCCCCCGCACGCAGCAGGTCATITKCCATA 2240

TGTACTATA TGACCCCACAGCTACAGATGCAAARCAACACCACAGACATGGATATGAAAACCTGAGAATTGTGGACTG

$\begin{array}{lllllll}2250 & 2260 & 2270 & 2280 & 2290 & 2300 & 2310\end{array}$

Seq. GenBank vP1 TGTACTATATGACCCCACAGCTACAGATGCAAACACACCACAGACATGGATATGARAGCCTGAGARTGTGGACBG 2320 Consenso VP1 TGTACTATA TGACCCCACAGCTACAGATGCAAARCAACACCACAGACATGGATATGAAAACCTGARGATTGTGGACTG 2320

CCAARAGCCGTGTGCACCCATTGTA

$$
2330 \quad 2340
$$

Seq. GenBank VP1 CCAAhAGCCGTGTGCACCCATTGTA 


\section{Anexo B}

Análise do sequenciamento do gene que codifica a proteína VP2 (1664 nt), clonada no plasmídio pPIC9K-VP2: alinhamento com a seqüência do vírus B19 (Ref. M13178, Shade et al., 1986) GenBank.

ATGACTTCAGTTAATCTGCAGAAGCCAGCACTGGTGCAGGAGGGGGGGGGAGTMTICTGTCAMAGCATGTGGAGTGA

$\begin{array}{llllllll}10 & 20 & 30 & 40 & 50 & 60 & 70 & 80\end{array}$

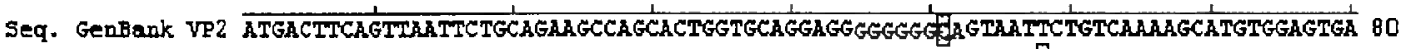
Consenso VP2 ATGACTTCAGTAATTCTCAGAGCCAGCACTGGTGCAGGAGGGGGGGGATAA ECTGTCAAAAGCATGTGGAGTGA 80

GGGGGCCACTTTTAGTGCTAACTCTGTAACTTGTACATTTTCCAGACAGTTTTTAATCCATATGACCCAGAGCACCATT

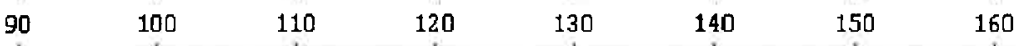

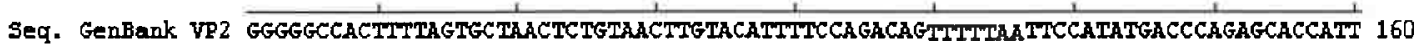
consenso VP2 GGGGGCCACTTTTAGTGCAAACTCTGTAACTTGTACATTTTCAGACAGTTTTTAATCCATATGACCCAGAGCACCATT 160

ATAAGGTGTTTTTCCCGCA GCGAGTAGCTGCCACAATGCCAGTGGAAAGGAGGCAAAGGTTTGCACCATTAGTCCCATA

$\begin{array}{lllllll}170 & 180 & 190 & 200 & 210 & 220 & 230\end{array}$

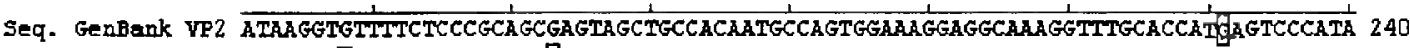

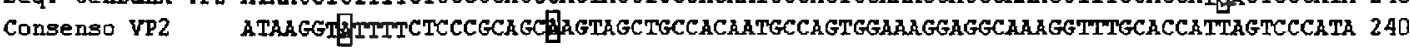

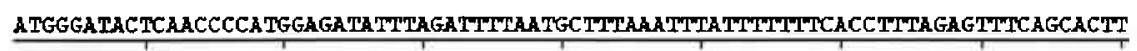

$\begin{array}{lllllll}250 & 260 & 270 & 280 & 290 & 300 & 310\end{array}$

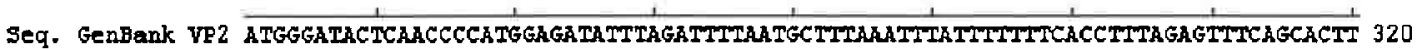

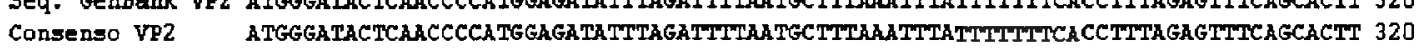

AATTGAMATTATGGAGTATAGCTCCTGATGC TTLAACTGTAACCATATCAGAAATGCTGTTAGGATGTTACAGACA

\begin{tabular}{|c|c|c|c|c|c|}
\hline 330 & 340 & 350 & 360 & 370 & 380 \\
\hline
\end{tabular}

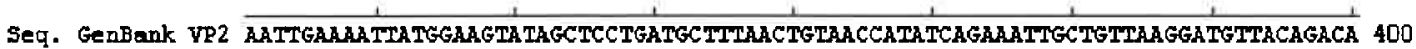
Consenso VP2 AATTGAAATTATGGAGTATAGCTCCTGATGCTTTACTGTAACCATATCAGAAATTGCTGTTAGGATGTTACAGACA 40D

AAACTGGAGGGGGGGTACAGGTTACTGACAGCACTACAGGGCGCCTATGCATGTTAGTGGACCATGAATACAAGTACCCA

$\begin{array}{lllllll}410 & 420 & 430 & 440 & 450 & 460 & 470\end{array}$

Seq. GenBank V2 AAACTGGAGGGGGGTACAGGTIACTGACAGCACTACAGGGCGCTATGCATGTLAGTigACCATGAATACAAGTACCCA 480 Consenso VP2 AAACTGGAGGGGGGTACAGGTTACTGACAGCACTACAGGGCGCCTATGCATGTTAGTGGACCATGAATACAAGTACCCA 480

TATGTGTTAGGGCAAGGTCAGGATACTITAGCCCCAGAACTTCCTATTTGGGTGTACTTTCCTCCTCAATATGCTTACTT

$$
\begin{array}{lllllll}
490 & 500 & 510 & 520 & 530 & 540 & 550
\end{array}
$$

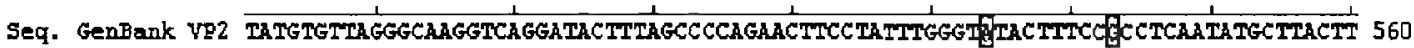
Consenso VP2 TATGTGTIAGGCAAGGTCAGATACTTTAGCCCCAGACTTCCTATTTGGGTGTACTTTCCTCCTCAATATGCTIACTT 560

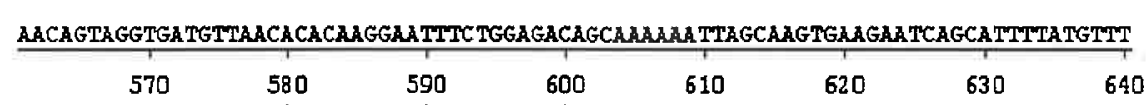

Seq. GenBank VP2 AACA GTAGGjGATGTTACACACAAGGATTTC TGGAGACAGCAALAAATIAGCAAGTGAGAATCAGCATTTTATGTTT 640 Consenso VP2 AACAGTAGGTGATGTTAACACACA GGAATTTC TGGAGACAGCAAAAAATTAGCAAGTGAAGAATCAGCATTITATGTTT 64D

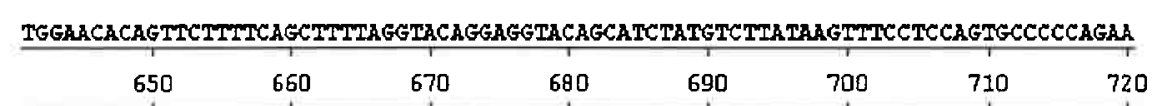

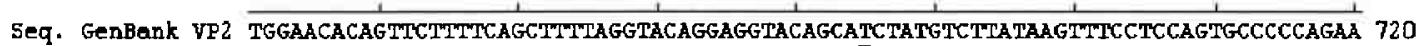
Consengo YP2 TGGAACACAGTTCTTTCAGCTTTIAGGTACAGGAGGTACAGCA FTATGTCTTATAAGTTTCCTCCAGTGCCCCCAGAA 720

AATTAGAGGGCTGCAGTCAACACTTTTATGAAATGTACA, ,

\begin{tabular}{|c|c|c|c|c|c|c|}
\hline 730 & 740 & 750 & 760 & 770 & 780 & 790 \\
\hline
\end{tabular}

seq. GenBank VP2 AATITAGAGGGCTGCAGTCAACACTTTTATGAATGTACAATCCCTTATACGGATCCCGCTPAGGGTTCCTGACACATT 800 Consenso VP2 AATTTAGAGGCTGCAGTCAACACTTTTATGAAATGTACAATCCCTTATACGGATCCCGCTTAGGGGTTCC TGACACATT 800

AGGAGGTGACCCAAAATTTAGATCTTTAACACATGAAGACCATGCARTTCAGCCCCAAAACTTCATGCCAGGGCCACTAG

$\begin{array}{llllllll}810 & 820 & 830 & 840 & 850 & 860 & 870 & 880\end{array}$

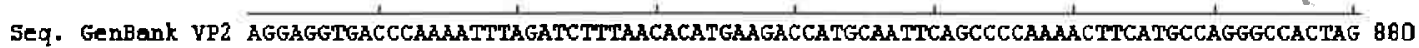
Consengo VP2 AGGAGGTGACCCAAAATTAGATCTTLACACATGAAGACCATGCAATTCAGCCCCAAAACTTCATGCCAGGGCCACTAG 880 


\section{TAAACTCAGTGTCTACARAGGGGGAGACAGCTCTAATACTEGAGCTGGAAAAGCCTTACAGGCCTTAGCACAGGTACC}

$\begin{array}{lllllll}890 & 900 & 910 & 920 & 930 & 940 & 950\end{array}$

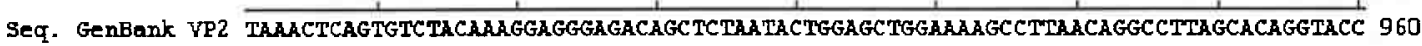
consenso VP2 TAAACTCAGTGTCTACAAAGGAGGAGACAGCTCTAATACTGGAGCTGGAAAAGCCTTAACAGGCCTTAGCACAGGTACC 960

TCTCAAAACACTAGARTATCCTACGCCCTGGGCCAGTGTCTCAGCCATACCACCACTGGGACACAGATAARTATGTCAC
970
980
990
1000
1010
1020
$1030 \quad 1040$

Seq. GenBank VP2 TCTCABACACThGATTTCCTTACGCCCTGGGCCAGTGTCTCAGCCATACCACCACTGGGACACAGATAATATGTCAC 1040 Consenso VP2 TCTCAAAACACTAGAATA TCCTTRCGCCCTGGCCAGTGTCTCAGCCATACCACCACTGGGACACAGATAAATATGTCAC 1040

AGGAATAAATGCCATTTCTCATGGTCAGACCACTIATGGTAACGCTGAAGACAAAGAGTATCAGCAAGGAGTGGGTAGAT

$\begin{array}{lllllll}1050 & 1060 & 1070 & 1000 & 1090 & 1100 & 1110\end{array}$

Seq. GenBank VP2 AGGATTAATGCCATTTCTCATGGTCAGACCACTTATGGTAACGCTGAMGACAARGAGTATCAGCAAGGATGGGTAGAT 1120 consenso vP2 AGGATAAATCCATTTCTCATGGTCAGACCACTPAGGTACGCTGAMGACAAAGAGTATCACARGAGTGGGTAGAT 1120

TRCCAARTGAAAAGACAGCTAAAACAGTIACAGGGTTTAAACATGCACACCTACTTTCCCAATAAAGGAACCCAGCAA
1130
1140
1150
1160
1170
1180
$1190 \quad 1200$

Seq. GenBank vP2 TTCCAAATGAAAAAGAACAGCThAAACAGTTACAGGGTTMAACATGCACACCTACTFTCCCAATAAAGGAACCCAGCAA 1200 Consenso VP2

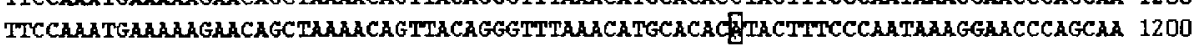

TATACAGATCAAATTGAGCGCCCCCTAATGGTGGGTTCTGTATGGAACAGAAGAGCCCTTCACTATGAAAGCCAGCTGTG

$\begin{array}{lllllll}1210 & 1220 & 1230 & 1240 & 1250 & 1260 & 1270\end{array}$

Seq. GenBank VP2 TATACAGATCAAATTGaCGCCCCCTAATGGTGGGTTCTGTATGGARCAGAGAGCCCTTCACTATGAAGCCAGCTGTG 1280 Consenso VP2 TATACAGATCAAATTGAGCGCCCCTAATGGTGGGTTCTGTATGGAACAGAAGAGCCTTCACTATGAAACCAGCTGTG 1280

GGGTAAAATTCAAATTTAGATGACAGTTTTAAAACTCAGTTTGCAGCCTTAGGAGGATGGGGTTIGCATCAGCCACCTC
1290
1300
1310
1320
1330
1340
$1350 \quad 1360$

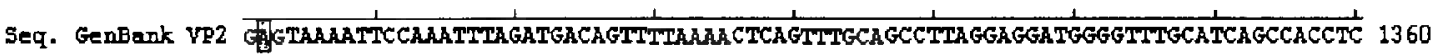
Consenso VP2 GGGTAAATTCCAAATTAGATGACAGTTTALAATCAGTTTGCAGCCTTAGGAGATGGGITIGCATCAGCCACCTC 1360

CTCAAATATTTTMAAAATATTACCACAAAGTGGGCCAATTGGAGGTATTAAATCAATGGGAATTACTACCTTAGTTCAG

$\begin{array}{llllllll}1370 & 1380 & 1390 & 1400 & 1410 & 1420 & 1430 & 1440\end{array}$

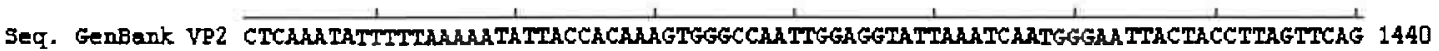
Consenso VP2 CTCAhA TATTTTLAAAATATTACCACAAATGGGCCATTGGAGGTATTARACARTGGGATTACTACCTTAGTTCAG 1440

TATGCCGTGGGAATTATGACAGTAACTATGACATTTAAATTGGGGCCCGTAAAGCTACGGGACGGTGGAATCCTCAACC

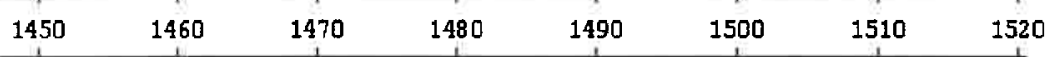

Seq. Genbank VP2 TATGCCGTGGGATTATGACAGTAACTATGACATTLAMTTGGGCCCCGTAAGCTACGGGACGGTEGAATCCTCAACC 1520 Consenso VP2 TATGCCGTGGGAATTAGACAGTAACTATGACATTTAAATTGGGGCCCCGTAAAGCTACGGGCGGTGGAATCCTCAACC 1520

TGGaGTTTATCCCCCGCACGCAGCAGGTCATTTACCATATGTACTGTATGACCCCACAGCTACAGATGCAAACAACACC

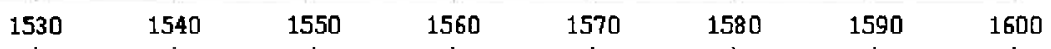

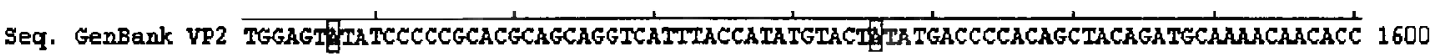
Consenso VR2 TGGAGTTARCCCCCGCACGCAGCAGGTCATTTACCATATGTACTETATGACCCCACAGCTACAGATGCAAAACAACACC 1600

ACAGACATGGATATGAAAAGCCTGAAGATTTGGGACAGCCAAAAGCCGTGTGCACCCATTGTA

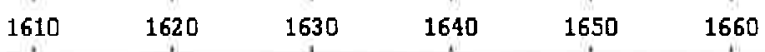

seq. GenEank vT2 ACAGACATGGaTh TGAAAGCCTGA GAATTGTGGACAGCCAARAGCGTGTGCACCCATTGTA

Comsenso VP2 ACAGACAGGGATGGAAAGCCTGAA GAATTGTGACAGCCAAAAGCGTGTGCACCCATTGTA 